\title{
Vahvempaa pohjoismaista oikeusyhteistyötä
}

Haasteita ja mahdollisuursia

(1) Pohjoismaiden ministerineuvosto

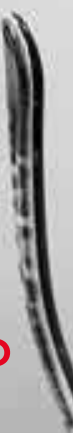


Vahvempaa pohjoismaista oikeusyhteistyötä

Haasteita ja mahdollisuuksia

ANP 2018:728

ISBN 978-92-893-5437-0 (PRINT)

ISBN 978-92-893-5438-7 (PDF)

ISBN 978-92-893-5436-3 (EPUB)

http://dx.doi.org/10.6027/ANP2018-728

(C) Pohjoismaiden ministerineuvosto 2018

Ulkoasu: Mette Agger Tang

Kannen valokuva: Ricky Molloy

Paino: Rosendahls

Printed in Denmark

Pohjoismainen yhteistyö

Pohjoismainen yhteistyö on yksi maailman laajimmista alveellisista yhteistyömuodoista. Yhteistyön piiriin kuuluvat Islanti, Norja, Ruotsi, Suomi ja Tanska sekä Ahvenanmaa, Färsaaret ja Grönlanti.

Pohjoismaista yhteistyötä tehdään politiikan, talouden ja kulttuurin aloilla tärkeänä osana eurooppalaista ja kansainvälistä yhteistyötä. Pohjoismaisen yhteisön tavoitteena on vahva Pohjola vahvassa Euroopassa.

Pohjoismainen yhteistyö pyrkii vahvistamaan pohjoismaisia ja alveellisia etuja ja arvoja globaalissa maailmassa. Maiden yhteiset arvot lujittavat osaltaan Pohjolan asemaa yhtenä maailman innovatiivisimmista ja kilpailukykyisimmistä alueista.

Pohjoismaiden ministerineuvosto

Nordens Hus

Ved Stranden 18

DK-1061 København K

www.norden.org

Pohjoismaisia julkaisuja voi ladata osoitteesta: www.norden.org/nordpub 


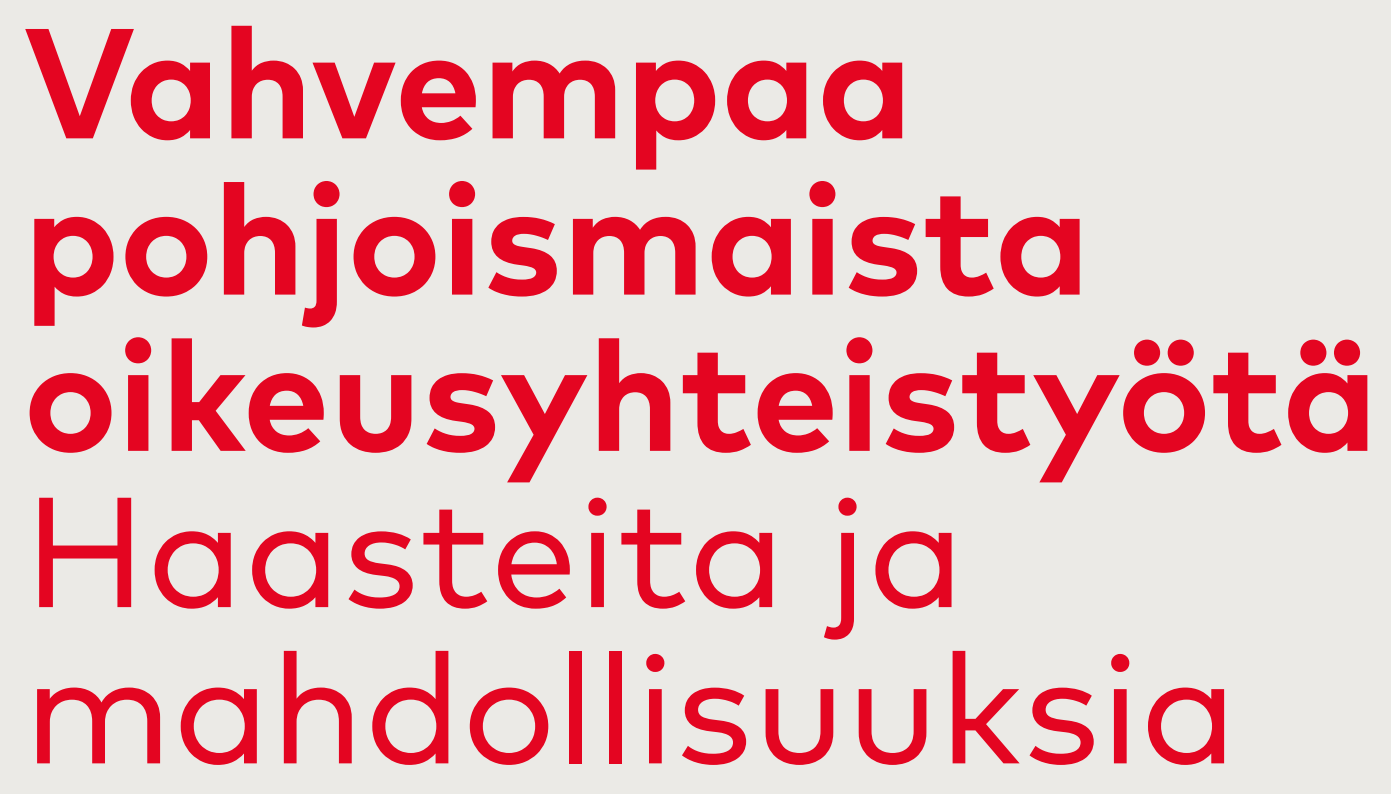

POHJOISMAIDEN MINISTERINEUVOSTON PÄÄSIHTEERILLE 24. TAMMIKUUTA 2018 LUOVUTETTU RAPORTTI

TEKIJÄ: EMERITUSPROFESSORI INGE LORANGE BACKER 



\section{Sisällys}

Esipuhe

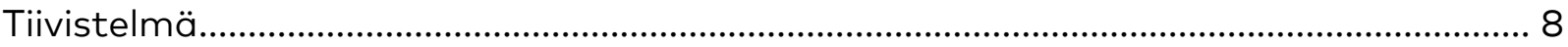

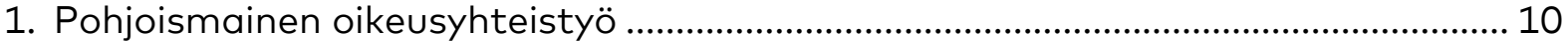

2. Miksi pohjoismaista oikeusyhteistyötä? ................................................................ 13

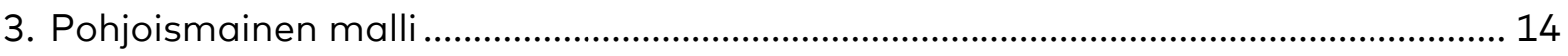

4. Pohjoismainen oikeusyhteistyö - kehitys ja nykyiset yhteistyömuodot ................... 17

5. Mikä edistää tai estää nykyistä pohjoismaista oikeusyhteistyötä?......................... 23

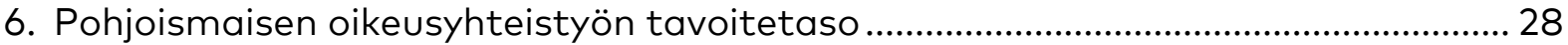

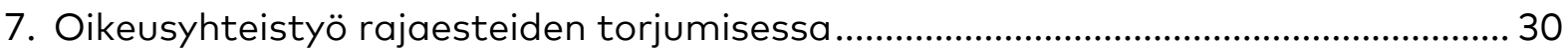

8. Pohjoismainen oikeusyhteistyö kansallisen lainsäädännön aloilla .......................... 33

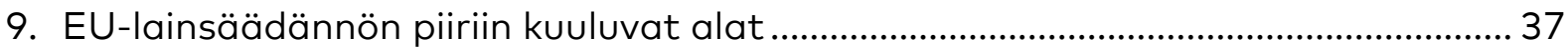

10. Pohjoismainen oikeusyhteistyö Ahvenanmaan,

Färsaarten ja Grönlannin kannalta ........................................................................... 41

11. Pohjoismainen oikeusyhteistyö - tiivistelmä vuoden 2018 tilanteesta ................... 43

12. Pohjoismaisen oikeusyhteistyön vahvistaminen .................................................... 46

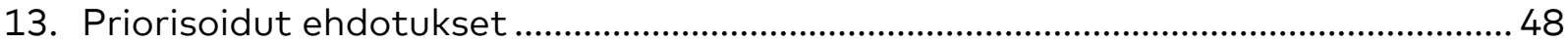

Liite 1 Yleisiä toimia pohjoismaisen oikeusyhteistyön vahvistamiseksi ......................... 52

Liite 2 Ajankohtaisia konkreettisia hankkeita tietyillä oikeuden ja elämän aloilla ........56 


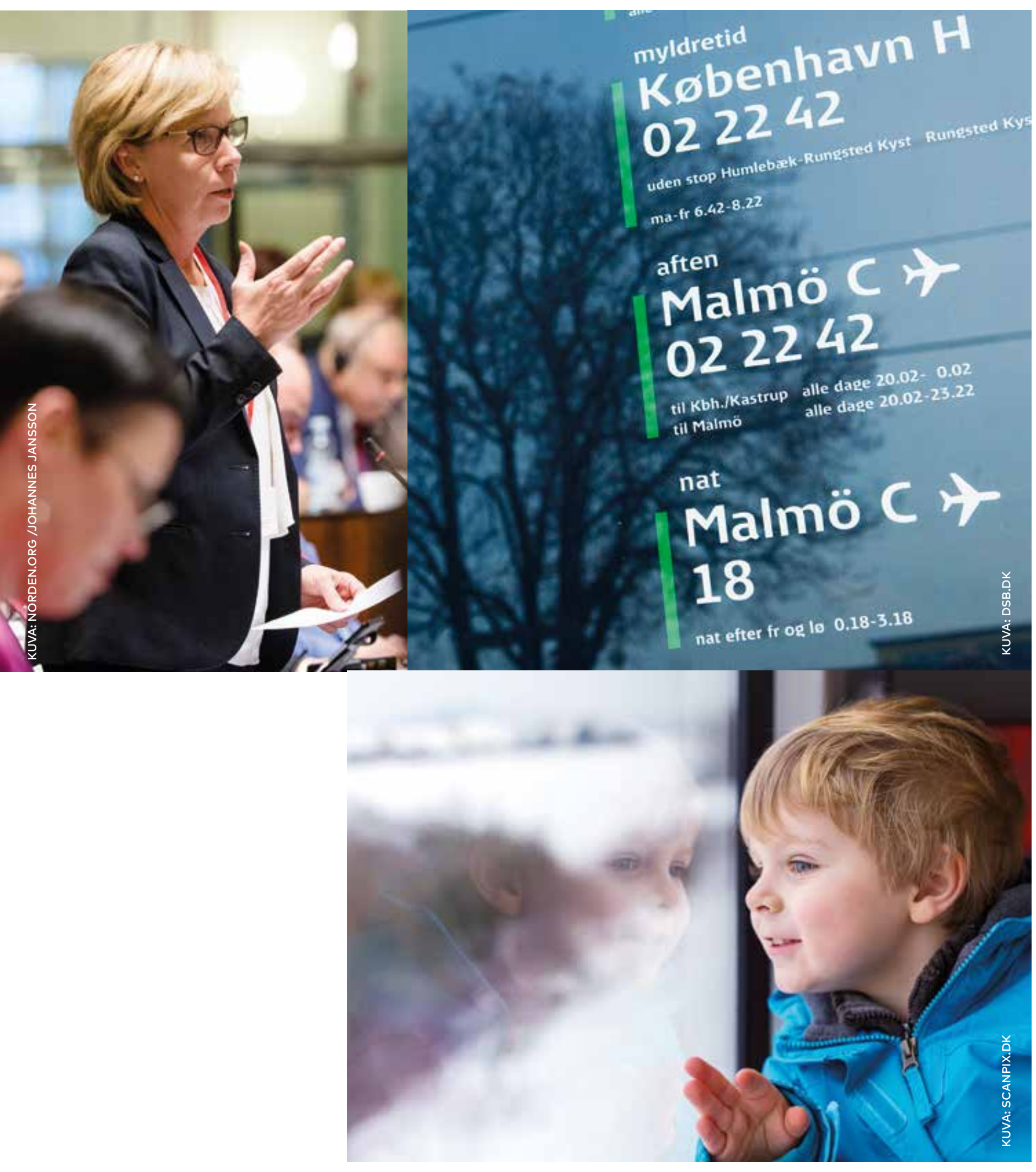




\section{Esipuhe}

Raportti on laadittu seurantana pohjoismaisten yhteistyöministereiden 6. syyskuuta 2016 tekemälle päätökselle, joka koski rajattua arviointia pohjoismaisen oikeusyhteistyön tulevista mahdollisuuksista tavoitteena kehittää pohjoismaista yhteistyötä ja vahvistaa Pohjoismaiden integraatiota. Pohjoismaiden pääministerien 27. syyskuuta 2016 antamassa julkilausumassa tavoitteena on tehdä Pohjoismaista maailman integroitunein alve. Tämä raportti on osa Pohjoismaiden ministerineuvostossa käynnissä olevaa uudistustyötä ja pääsihteerin laatiman Nyt Norden 2.0 -raportin suositusten täytäntöönpanoa yhteistyöministereiden syyskuussa 2016 tekemän päätöksen mukaisesti.

Keväällä 2017 Pohjoismaiden ministerineuvoston pääsihteeri antoi tehtäväkseni laatia analyysin pohjoismaisen oikeusyhteistyön vahvistamismahdollisuuksista. Analyysin toimeksiannossa tehtävää kuvataan seuraavasti:

"Analyysiin tulee muun muassa sisällyttää seuraavat osa-alveet:

- Tähänastisen pohjoismaisen oikeusyhteistyön arviointi

- Keskustelua ja ideoita pohjoismaisen oikeusyhteistyön mahdollisista muodoista tulevaisuudessa

- Keskustelua ja arvio vahvistetun yhteistyön mahdollisuuksista edistää rajaesteiden ratkaisemista

- Keskustelua ja arvio siitä, millä aloilla vahvempi pohjoismainen oikeusyhteistyö edistäisi eniten Pohjoismaiden integraatiota

- Keskustelua ja arvio siitä, millä aloilla on suurimmat mahdollisuudet laajentaa pohjoismaista yhteistyötä maiden EU-velvoitteet huomioon ottaen

- Arvio siitä, miten Pohjoismaat voivat hyötyä (laajemmasta) pohjoismaisesta oikeusyhteistyöstä
- Arvio (laajemman) pohjoismaisen oikeusyhteistyön kehityksen esteistä sekä niiden mahdollisesta ratkaisemisesta.

Analyysin tulee sisältää pohdintoja sekä oikeudellisista että poliittisista haasteista ja mahdollisuuksista, jotka liittyvät pohjoismaisen oikeusalan yhteistyön tiivistämiseen."

Tältä pohjalta olen laatinut analyysini "Vahvempaa pohjoismaista oikeusyhteistyötä - haasteita ja mahdollisuuksia". Heti esipuheen perässä on analyysin tiivistelmä, jossa keskitytään oikeusyhteistyön tuleviin vahvistamismahdollisuuksiin ja niiden toteuttamistapoihin.

Analyysin tärkeimpänä pohjana ovat lukuisat keskustelut ja kokoukset pohjoismaisten poliitikkojen, virkamiesten, asiantuntijoiden ja etujärjestöjen kanssa. Olen käynyt keskusteluja lähes 200 henkiIön kanssa kaikkialla Pohjoismaissa. Pohjoismaista oikeusyhteistyötä käsiteltiin laajasti Helsingissä 24.-25. elokuuta 2017 pidetyssä 41. pohjoismaisessa lakimieskokouksessa. Yhteistyöstä on myös laadittu runsaasti kirjallisia esityksiä, lähinnä lyhyehköjä artikkeleita ja mielipidekirjoituksia. Myös Pohjoismaiden ministerineuvoston aiemmat raportit ja muut julkaisut ovat olleet tärkeitä idealähteitä.

Työssäni minua ovat auttaneet suuresti Pohjoismaiden ministerineuvoston sihteeristön vanhempi erityisasiantuntija Kasper Paulig ja - hänen poissa ollessaan - vanhempi erityisasiantuntija Katrine de Neergaard. He ovat järjestäneet eri puolilla Pohjolaa pidettyjä keskusteluita ja seuranneet niitä, mikä on ollut korvaamaton apu.

Oslossa 24. tammikuuta 2018

Inge Lorange Backer 


\section{Tiivistelmä}

Pohjoismaista oikeusyhteistyötä voidaan vahvistaa monin eri tavoin.

Yhteistyön vahvistamisesta voi olla monenlaista hyötyä: se voi parantaa yksittäisten maiden lainsäädäntöä, torjua Pohjoismaiden välisiä ei-toivottuja rajaesteitä, kehittää ja edistää pohjoismaista mallia esimerkkinä maailmanyhteisölle. Vahvempi pohjoismainen oikeusyhteistyö on tärkeää toteutettaessa Pohjoismaiden pääministereiden yhteistä tavoitetta tehdä Pohjoismaista maailman integroitunein alve.

Pohjoismaisen oikeusyhteistyön vahvistaminen edellyttää aktiivista ja konkreettista poliittista tukea ja sitä, ettei lainvalmistelun parissa toimivien virkamiesten työtilanne ole esteenä seurannalle.

Pohjoismaista oikeusyhteistyötä on tehty yli 100 vuotta. Sinä aikana yhteispohjoismaisia lakeja on säädetty useilla eri aloilla, erityisesti yksityisoikeuden alalla. Tämä epävirallinen yhteistyö on pohjautunut pragmaattisiin neuvotteluihin ja keskusteluihin, joissa kaikki maat ovat säilyttäneet täyden riippumattomuutensa lainsäätäjinä. Joillakin aloilla Pohjoismaiden välillä on myös laadittu kansainvälisoikeudellisesti sitovia sopimuksia, mutta niistä ei ole olemassa hyvää kokonaiskatsausta. Tämän lisäksi yhteistyön puitteissa jaetaan paljon tietoa ja kokemuksia, joista on hyötyä maiden valmistellessa kansallisia lainsäädäntötoimiaan.

Pohjoismaisen oikeusyhteistyön tavoitetaso vaihtelee, ja pyrkimyksenä on joko yhtenäistää maiden lainsäädäntöä tai päästä yksimielisyyteen lainsäädännön rakenteesta tai periaatteista tai vaihtaa lainsäädäntötyötä koskevaa tietoa ja kokemuksia. Tavoitetasoa voidaan muokata tarpeen mukaan ja yhteistyöhön voi ryhtyä kaksi tai useampaa maata ilman, että kaikkien maiden tarvitsee olla mukana.

Pohjoismaiden oikeudellisesta yhteistyöstä on määrätty 23. maaliskuuta 1962 solmitun yleissopimuksen (Helsingin sopimus) artikloissa 2-7. Tavoitteet ovat korkeimmat yksityisoikeuden alalla, jossa pyritään saavuttamaan mahdollisimman suuri yhdenmukaisuus (artikla 4), kun taas rikosoikeuden alalla pyritään yhdenmukaistamaan yksittäisiä säännöksiä (artikla 5). Lisäksi on pyrittävä muunkin lainsäädännön keskinäiseen yhtenäistämiseen tarkoituksenmukaisilla aloilla (artikla 6). Sopimus sisältää myös säännöksiä tuomioistuimen tai muun viranomaisen päätöksen hyväksymisestä ja täytäntöön panemisesta vastavuoroisesti maissa (artikla 7) sekä säännöksen Pohjoismaiden kansalaisten yhdenvertaisesta kohtelusta (artikla 2). Oikeusyhteistyö vaikuttaa myös eri politiikan alojen yhteistyötä koskeviin määräyksiin, esimerkiksi koulutuksen, työoikeuden, sosiaalietuuksien ja ympäristönsuojelun alalla. Helsingin sopimuksen mukaan mailla on velvollisuus tiedottaa toisiaan, mikäli ne tekevät muutoksia pohjoismaisen yhteistyön puitteissa laadittuun lainsäädäntöön (artikla 41).

Maiden EU- ja Eta-jäsenyydet ovat edistäneet Pohjoismaiden lainsäädännön yhtenäisyyttä osana eurooppalaista yhtenäistämistä. Ne ovat toisaalta rajoittaneet Pohjoismaiden mahdollisuuksia tehdä vapaamuotoista oikeusyhteistyötä ja erityisesti solmia uusia pohjoismaisia yleissopimuksia, mutta toisaalta ne muodostavat yhteistyöpohjan EU- ja Eta-säädösten valmisteluun tai täytäntöönpanoon. Yhteistyön vahvuus on kuitenkin vaihdellut. Kansallisen täytäntöönpanon erot ovat voineet aiheuttaa uusia lainsäädännön eroja, mutta asian laajuudesta ei ole koottua empiiristä katsausta.

Pohjoismainen oikeusyhteistyö on epävirallista, minkä seurauksena yhteistyön käynnistäminen ja seuraaminen on helppoa. Epävirallisen luonteensa takia yhteistyö jää käytännössä kuitenkin maissa muiden kansainvälisten velvoitteiden ja helposti myös muiden työtehtävien jalkoihin. Lisääntynyt tietämys Helsingin sopimukseen liittyvistä velvoittavista odotuksista voi edistää pohjoismaisen oikeusyhteistyön vahvistamista.

Poliittisella tasolla voi olla havaittavissa tiettyä tyytymättömyyttä pohjoismaista oikeusyhteistyö- 
tä koskevien signaalien ja aloitteiden seurantaan. Virkamiestasolla vastavuoroista tietojen ja kokemusten vaihtoa pidetään toimivana ja hyödyllisenä kansallisen lainvalmistelun kannalta. Virkamiesten keskuudessa ollaan yleisesti sitä mieltä, ettei laajempaan oikeusyhteistyöhön, jonka tavoitteena olisi yhtenäinen lainsäädäntö niin sisällöllisesti kuin rakenteellisesti, ole aikaa ja resursseja eikä siitä saataisi tarpeeksi konkreettista hyötyä.

Yhteistyötä vahvistaisi, mikäli Pohjoismaiden neuvosto ja Pohjoismaiden ministerineuvosto tekevät selkeitä ja konkreettisia poliittisia aloitteita. Uudet työtavat, erityisesti varhainen tiedotus, yhteistyötoimien arviointi ja ministeriöiden ulkopuolisten asiantuntijaympäristöjen aktiivisempi hyödyntäminen helpottaisivat yhteistyön toteuttamista.

Pohjoismaiden ministerineuvostossa oikeusyhteistyötä tehdään lähinnä yksittäisiä asioita koskevien yhteisten selvitysten sekä pohjoismaisten seminaarien ja niistä laadittavien raporttien muodossa. Joidenkin selvitysten ja raporttien osalta on epäselvää, miten niitä seurataan. Pysyvänä käytäntönä tulee olla, että ministerineuvosto ottaa kantaa jatkoseurantaan, ja tällöin tietyillä mailla tulee olla mahdollisuus jatkaa lainsäädännöllistä yhteistyötä, vaikkeivät kaikki maat osallistu siihen.

Tarpeettomia rajaesteitä voidaan torjua, mikäli maat määrittävät oman lainvalmistelunsa suuntaviivoissa, että lain vaikutuksia muihin pohjoismaa- laisiin ja Pohjoismaihin on arvioitava oleellisilta osin. Uusia rajaesteitä torjutaan myös, jos jokainen maa antaa Helsingin sopimuksen artiklan 41 mukaisesti ilmoituksen muille Pohjoismaille harkitessaan muutoksia pohjoismaisen yhteistyön puitteissa laadittuun lainsäädäntöön.

Pohjoismaista oikeusyhteistyötä voidaan vahvistaa usein eri keinoin. On tärkeää selvittää ajankohtaisia mahdollisuuksia ja tarttua niihin. Tässä raportissa on kahteen pääryhmään jaettuja ehdotuksia pohjoismaisen yhteistyön vahvistamiseksi lyhyellä ja pidemmällä aikavälillä. Raportissa esitellään 13 ehdotusta.

Ehdotusten ensimmäinen pääryhmä koskee kansallisen tai pohjoismaisen tason rutiinien muuttamista, organisatorisia toimia pohjoismaisella tasolla ja Pohjoismaiden resurssien ja asiantuntijayhteisöjen parempaa hyödyntämistä. Toisen pääryhmän ehdotuksissa käsitellään konkreettisia lainsäädäntöaloja ja -hankkeita. Ehdotusten valintakriteereinä ovat olleet pohjoismainen hyöty, yhteiskunnan ajankohtaiset ongelmat ja se, onko pohjoismaisen yhteistyön jatkamiselle alakohtaisia perusteluja.

Kaikkia ehdotuksia syvennetään tietyssä määrin liitteissä 1 ja 2, joissa käsitellään myös pohjoismaisen oikeusyhteistyön muutamia muita mahdollisia aiheita. 


\section{Pohjoismainen oikeusyhteistyö}

\section{Mitä on pohjoismainen oikeusyhteistyö?}

Pohjoismaista oikeusyhteistyötä tehdään Pohjoismaiden välisenä yhteistyönä lainsäädännön alalla. Kyse on pääasiassa uusien lakiesitysten valmistelusta ja laatimisesta maiden parlamenttien hyväksyttäväksi. Oikeusyhteistyö voi koskea lukuisten eri alojen lainsäädäntöä. Perinteisesti yhteistyö on ollut vahvinta tuomioistuinten lainkäyttöön liittyvien yleisten säädösten alalla, etenkin yksityishenkilöiden väliseen suhteeseen kuuluvien yksityisoikeudellisten säännösten parissa.

Alun perin oikeusyhteistyötä tehtiin Norjan, Ruotsin ja Tanskan välillä yleistä lainsäädäntöä koskevissa asioissa ja lähinnä oikeusministeriöiden vastuualueilla. Suomi liittyi yhteistyöhön maan itsenäistyttyä vuonna 1917, ja Islanti tuli mukaan myöhemmin. Tavallisesti kaikki viisi Pohjoismaata ovat osallistuneet oikeusyhteistyöhön. Yksittäisissä tapauksissa Islanti ei ole kuitenkaan resurssisyistä osallistunut yhteistyöhön aktiivisesti.

Raportissa keskitytään lainsäädännön valmistelua ja laatimista koskevaan yhteistyöhön Pohjoismaiden välillä. Lisäksi esille otetaan muutamia kohtia lainsäädännön noudattamisesta. Raportin lähtökohtana on, että maan lait säädetään sen omassa parlamentissa. Pohjoismaista yhteistyötä säätelevä Helsingin sopimus vuodelta 1962 ei sisällä mahdollisuutta ylikansallisiin järjestelmiin niin, että Pohjoismaiden neuvosto tai muut pohjoismaiset laitokset hyväksyisivät kaikkia maita sitovia lakeja, eikä raportissa myöskään käsitellä tämäntyyppisiä järjestelmiä. Pohjoismaiden neuvostolla ja Pohjoismaiden ministerineuvostolla voi kuitenkin olla merkittävä asema Pohjoismaiden oikeusyhteistyössä.

\section{Oikeusyhteistyö ja muu pohjoismainen yhteistyö Lainsäädännön tulee säännellä yhteiskunnan ajankohtaisia asioita ja ratkaista yhteiskunnas- sa esiintyviä ristiriitoja. Sekä arvovalinnat että ajankohtaisia kysymyksiä koskeva analyysi vaikut- tavat lainsäädännön sisältöön. Jos asia on selvästi}

ratkaistava lainsäädännön avulla, empiiristä tietoa voidaan kerätä ja ongelmaa analysoida usein lainvalmistelun yhteydessä. Jos asian ratkaisemiseen ei välttämättä tarvita lain keinoja, kyseistä ongelmaa analysoidaan ennen kuin lainvalmistelu mahdollisesti käynnistyy.

Pohjoismaista yhteistyötä tehdään suurelta osin muiden asioiden kuin lainsäädännön parissa. Myös tässä yhteistyössä saattaa nousta esille asioita, joiden ratkaisemiseen tarvitaan lainsäädäntöä. Oikeusyhteistyön ja muun pohjoismaisen yhteistyön välillä ei sen vuoksi tarvitse tehdä jyrkkää eroa.

\section{Oikeusyhteistyön erilaiset tavoitteet ja tavoitetasot}

Oikeusyhteistyön tavoitteet ja tavoitetasot voivat vaihdella. Tavoitteena voi olla tiedon ja kokemusten vaihto, ongelmien yhteinen selvittäminen ja analysointi sekä enemmän tai vähemmän yhdenmukaiset lakiesitykset kaikissa maissa. Pohjoismaiden välisessä oikeusyhteistyössä voidaan myös arvioida yhdessä tiettyjen asioiden lainsäädäntöä, minkä seurauksena saatetaan tehdä aloitteita lainsäädännön uudistamiseksi.

Kun oikeusyhteistyön tavoitteena on yhtenäisempi lainsäädäntö Pohjoismaissa, jokaiselle yhteistyöhön osallistuvalle maalle laaditaan tavallisesti oma lakiehdotus. Vain joissakin tapauksissa epävirallisesta yksimielisyydestä on tullut kansainvälisoikeudellisesti sitovaa maiden solmimalla yleissopimuksella, jossa määritetään, mitä sääntöjä kunkin maan on sisällytettävä lainsäädäntöönsä.

Pohjoismaisen oikeusyhteistyön tavoitteena voi myös olla yhteinen rintama joko uutta yleissopimusta tai muita välineitä koskevissa kansainvälisissä neuvotteluissa tai muita maita mahdollisesti kiinnostavan ratkaisun esittelyssä.

Vuoteen 1980 asti oikeusyhteistyön painopisteenä oli yhtenäisten lakien laatiminen lähinnä yksityisoikeudellisissa asioissa, jotka koskevat yksityishenkilöiden välisiä, yleisissä tuomioistuimis- 


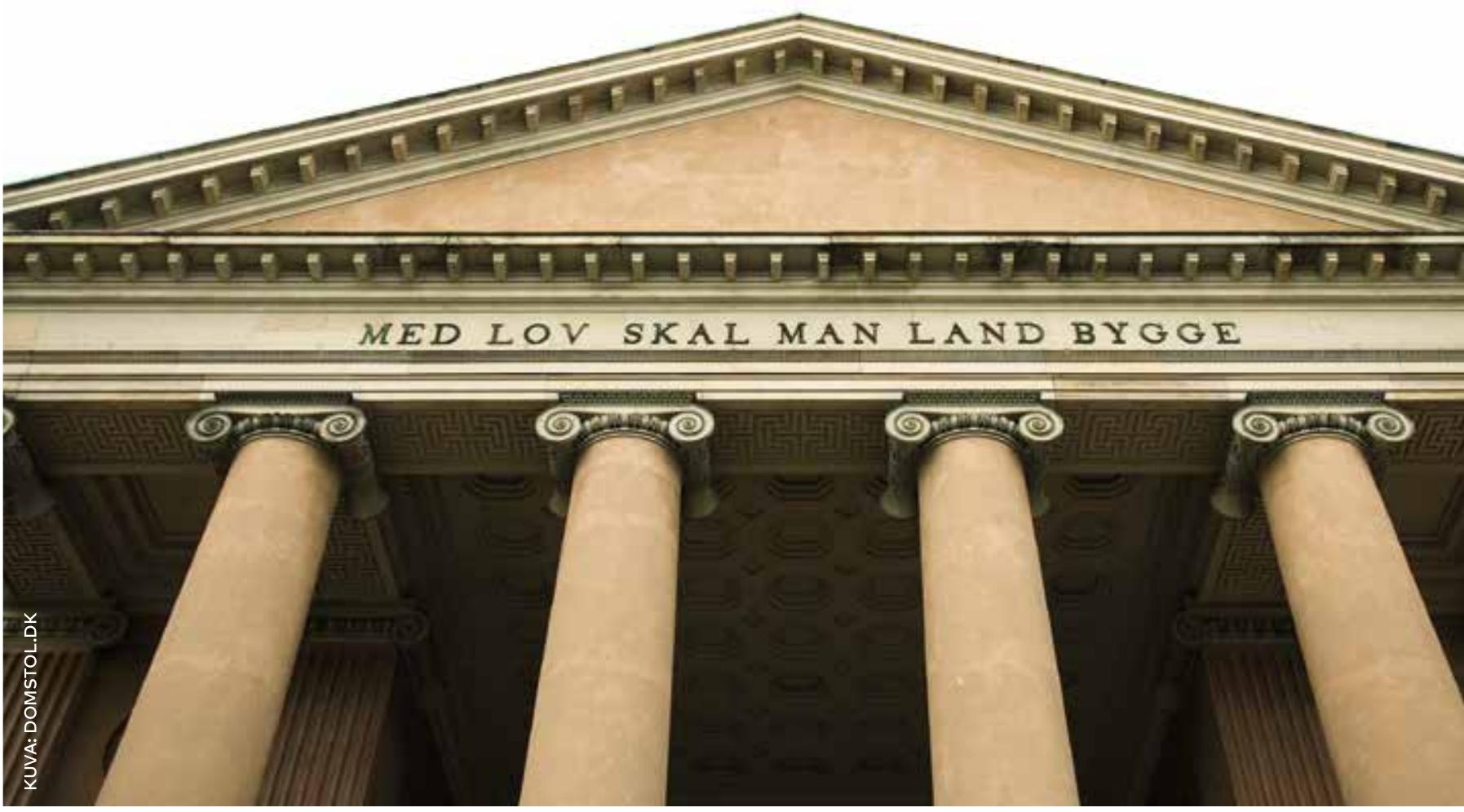

sa käsiteltäviä oikeussuhteita. Usein tuloksena oli aiemmin lakiin kirjaamattomien, lähes samankaltaisten säännösten vahvistaminen lailla tai kansainvälisten sopimusten yhtenäinen sisällyttäminen kaikkien maiden lainsäädäntöön. Myöhemmin yhteistyön lähtökohtana ovat usein olleet Pohjoismaiden ajankohtaiset konkreettiset ongelmat tai työ uusien EU- tai Eta-säädösten parissa. Joillakin aloilla on tehty tiivistä yhteistyötä uusien kansainvälisten yleissopimusten valmistelussa.

\section{Lainsäädäntö ja lakien täytäntöönpano - oikeusyhteistyö ja viranomaisyhteistyö}

Pohjoismaisen yhteistyön puitteissa laadittuja lakeja tulee soveltaa ja panna täytäntöön jokaisessa maassa. Joskus herää kysymyksiä lakien ymmärtämisestä ja soveltamisesta. Lain piiriin kuuluvat teot ja olosuhteet voivat koskea useimpia maita ja samantyyppisiä kysymyksiä voi esiintyä monessa maassa. Lainsäädäntöalan seurantayhteistyöllä Pohjoismaat voivat edistää lainsäädännön tavoitteen saavuttamista ja myös hyväksytyn lainsäädännön muutostarpeiden selvittämistä.

Käytännön yhteistyö Pohjoismaiden viranomaisten välillä on monissa asioissa laajempaa ja tiiviimpää kuin alalla tehtävä oikeusyhteistyö. Rahoitusvalvonnan ja keskuspankkien yhteistyö finanssialalla vaikuttaa oikeusyhteistyötä tiiviimmältä. Lainkäytön osalta korkeimpien oikeuksien edustajat ovat tiivistäneet yhteydenpitoaan, ja sama koskee valtakunnansyyttäjiä. Näitä yhteyksiä ylläpidetään nykyisen oikeusyhteistyön lisäksi. 


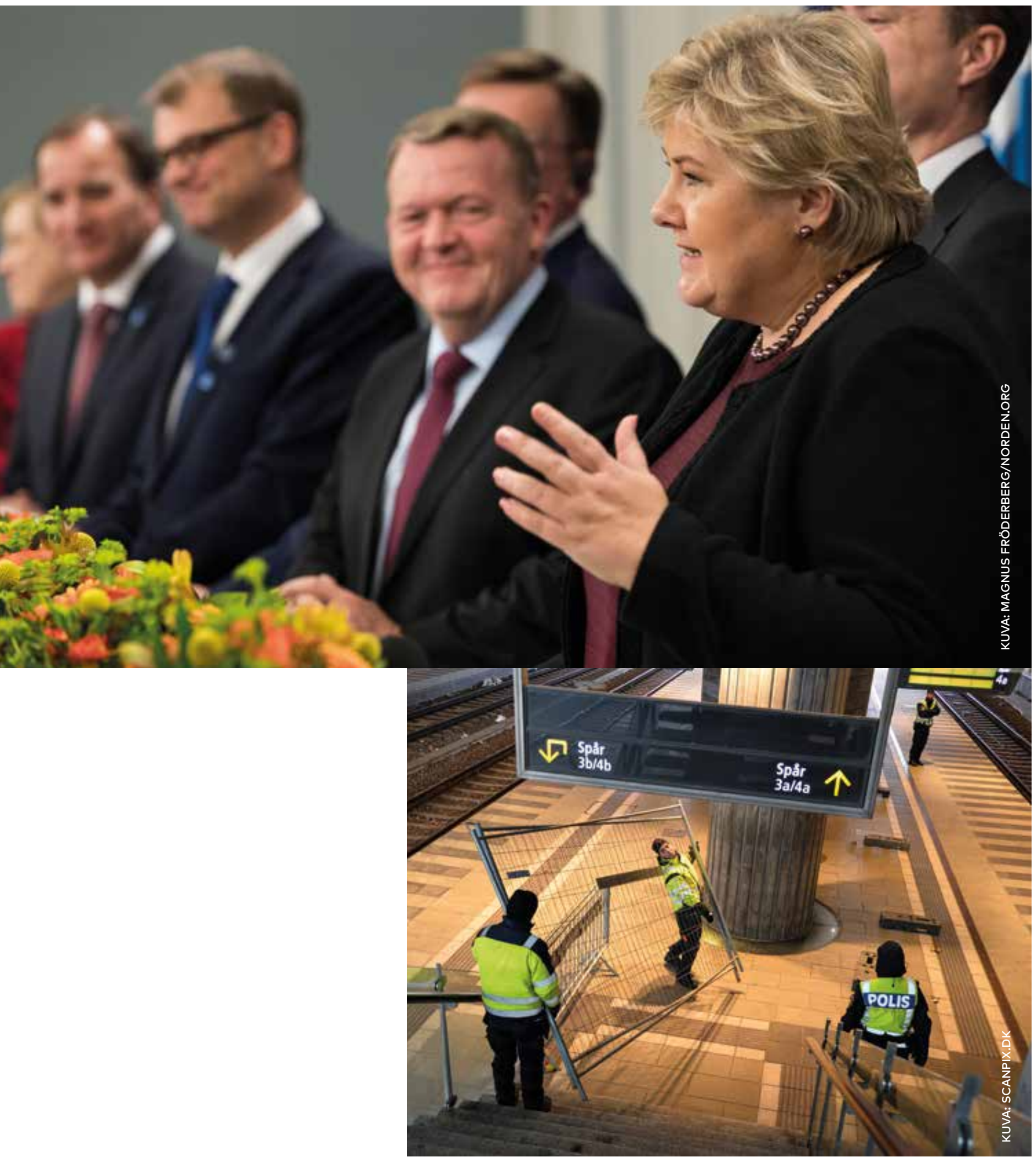




\section{Miksi pohjoismaista oikeusyhteistyötä?}

\section{Pääministereiden julkilausuma integroituneesta Pohjolasta}

Viiden Pohjoismaan pääministerit antoivat 27. syyskuuta 2016 yhteisen julkilausuman siitä, että Pohjoismaiden tulee olla maailman integroitunein alve.

Alveen lainsäädäntö lvo pohjan alveen yhteistoiminnalle ja kertoo sen vuoksi paljon siitä, miten integroitunut alue on. Euroopan unioni (EU) on paras esimerkki siitä, miten integraatiota edistetään yhteisillä oikeussäännöillä. Pääministereiden vision toteuttamisessa tarvitaan hyvää pohjoismaista oikeusyhteistyötä.

\section{Maiden rajat ylittävä liikkuvuus ja toiminta}

Pohjoismaiden välinen liikkuvuus on suurta. Tietyillä aloilla liikkuvuus on lisääntynyt merkittävästi viime aikoina. Liikkuvuus koskee sekä yksityishenkilöitä että elinkeinoelämää.

Yksityishenkilöt oleskelevat usein toisessa Pohjoismaassa lyhyen tai pidemmän aikaa. He saattavat myös muuttaa toiseen Pohjoismaahan, työskennellä ja perustaa perheen siellä. Henkilön hyvinvointi ja onni voivat kasvaa tämän ansiosta. Maiden rajojen ylittäminen on helpompaa, kun henkilö tunnistaa naapurimaassa tuttuja piirteitä historiallisen taustan sekä samankaltaisten yhteiskunta- ja luonnonolojen ja ehkä myös kielen ansiosta. Mahdollisia esteitä ovat kuitenkin yllätyksiä ja pettymyksiä aiheuttavat erot etenkin naapurimaan lainsäädännössä.

Elinkeinoelämälle Pohjoismaat merkitsevät pääsyä yksittäistä maata suuremmille markkinoille. Mahdollisuus perustaa yritys ja tarjota tuotteita ja palveluita maiden rajojen yli voi parantaa yksittäisen yrityksen kannattavuutta ja lisätä tai tehostaa tarjontaa asiakkaille. Tällä on erityisen suuri merkitys joko hyvin kapeaa erityisalaa edustaville tai tuotantovaiheen erityisosaamista edellyttäville palveluille ja tuotteille. Maiden rajat ylittävä yhteistyö voi vahvistaa pohjoismaisen elinkeinoelämän asemaa kansainvälisessä kilpailussa. Tällaisen yhteistyön käynnistäminen saattaa käydä sitä helpommin, mitä selkeämpi pohjoismainen oikeusyhteisö on.

\section{Rajaesteiden ennaltaehkäisy ja torjunta}

Pohjoismaisessa yhteistyössä on tämän vuoksi jo kauan priorisoitu maiden rajat ylittävää liikkuvuutta mahdollisesti vaikeuttavien "rajaesteiden" selvittämistä ja poistamista. Osa tällaisista rajaesteistä johtuu Pohjoismaiden asetusten tai muiden sääntöjen eroista tai lakien ja sääntöjen toimeenpanon eroista. Muut rajaesteet johtuvat suoraan lainsäädännön eroista, joita voidaan ehkäistä tai poistaa tehokkaalla pohjoismaisella oikeusyhteistyöllä.

Rajaeste voi muodostua jo siitä, että voi olla välttämätöntä perehtyä toisen Pohjoismaan erilaisiin sääntöihin. Tehtävä on helpompi, mikäli alan lainsäädäntö noudattaa samaa kaavaa. Silloin on myös selkeämmin havaittavissa, mistä eroista yksityishenkilön tai yrityksen tulee olla tietoisia.

\section{Pohjoismaiden yhteiskuntien resurssien jakaminen ja hyödyntäminen \\ Kun yhteiskunnan resurssien tehokas käyttö on tärkeää, pohjoismainen yhteistyö voi edistää hyvien palveluiden varmistamista asukkaille. Tämä voi esi- merkiksi koskea naapurimaan palveluita tai toimia raja-alueilla. Erityistason julkisissa palveluissa voi olla ajankohtaista tehdä työnjako, jonka mukaan tietyissä Pohjoismaissa palveluita voivat käyttää myös muissa maissa asuvat. Tällainen resurssien yhteiskäyttö edellyttää usein asian kirjaamista lainsäädäntöön.}

\section{Oppia toisilta}

Pohjoismailla on yhdessä huomattavasti enemmän kokemusta lainsäädännön ongelmakohdista kuin yksittäisillä mailla. Sillä tavoin maat voivat oppia toisiltaan ja laatia ajan mittaan mahdollisimman hyviä lakeja ja säädöksiä maiden yhteisten tavoitteiden saavuttamiseksi. Aiemmin pohjoismaisella oikeusyhteistyöllä tavoiteltiin pääasiassa laadukkaampaa lainsäädäntöä kuin mihin maat yksin olisivat pystyneet. 


\section{Pohjoismainen malli}

\section{Peruspiirteet ja erot}

Pohjoismaiden yhteiset arvot sekä yhteiskuntien ja luonnon samankaltaisuus ovat tärkeä osa yhteiskunnan järjestäytymistä kuvaavaa pohjoismaista mallia. Demokratia ja oikeusvaltio muodostavat Pohjoismaiden hallintotavan perustan. Olennainen osa sitä on ihmisten välinen tasa-arvo. Yksilön vapaudet ja oikeudet yhdistyvät yhteiskunnan solidaarisuutta ilmentäviin universaaleihin ratkaisuihin ja toimiin heikkojen ryhmien suojelemiseksi. Pohjoismaisessa mallissa on kuitenkin samanaikaisesti tilaa myös maiden välisille eroille ja erityispiirteille, mikä ilmenee eri tavoin niin Pohjoismaiden oikeusajattelussa ja lainsäädännössä kuin työelämässä ja vapaa-ajassakin.

Pohjoismaisen mallin myötä Pohjoismaat ovat maailman kärkisijoilla asukkaidensa hyvinvoinnin ja onnellisuuden turvaamisessa. Pohjoismainen malli yhdistetään usein avoimeen yhteiskuntaan, jossa niin asukkaiden keskinäinen kuin julkisten viranomaistenkin nauttima luottamus on suurta ja jolle ovat luonteenomaisia korkea hyvinvointi, sosiaaliturva ja tasa-arvo.

\section{Pohjoismainen malli eri aloilla}

Työelämäalalla ajatellaan erityisesti työnantaja- ja ammattijärjestöjen - joilla kummallakin on huomattava jäsenmäärä - sekä valtion välistä kolmikantayhteistyötä. Hyvällä kolmikantayhteistyöllä uskotaan olevan tärkeä merkitys Pohjoismaille työrauhan ja talouskasvun kannalta. Pohjoismaiseen malliin kuuluu myös tasapainoinen sääntely, joka osaksi tapahtuu lainsäädännön kautta ja osaksi organisaatioiden välisten sopimusten kautta.

Pohjoismaiden sosiaaliturva perustuu laajaan julkiseen tukijärjestelmään apua tarvitsevalle ja lähtökohtaisesti universaaleihin palveluihin. Sen edellytyksenä on, että jokainen antaa kykynsä mukaan oman panoksensa yhteiseksi hyväksi ja osallistuu kansalaisten välistä tasa-arvoa edistävän tukijärjestelmän rahoitukseen. Maissa voi lisäksi olla erilaajuisia vapaaehtoisia järjestelmiä.

Elinkeinoelämässä puhutaan yritysjohtamisen pohjoismaisesta mallista: osakeyhtiöissä enemmistöosakkaille on taattu tehokkaat mahdollisuudet johtaa yrityksen kehitystä samalla, kun vähemmistöosakkaiden oikeuksista on huolehdittu.

Kuluttaja-alalla pohjoismaisessa mallissa yhdistyvät yksittäisen kuluttajan mahdollisuudet vaatia oikeuksiaan ja kuluttajien yleisiä etuja valvovat julkiset elimet. Monet kuluttajan etua valvovat säännöt on muotoiltu yleisinä standardeina, jotka mahdollistavat joustavien ja konkreettisten arviointien tekemisen vaihtuvissa markkinatilanteissa. Tuomioistuinten ulkopuolisissa riita-asioiden sovittelvelimissä on sekä elinkeinoelämän että kuluttajien edustajia.

Julkishallinto on organisoitu eri tavoin eri Pohjoismaissa, mutta se pohjautuu hallinnon yhteiseen arvoperustaan. Hallinnon tulee olla asiallista, asiantuntevaa ja lahjomatonta. Sen tulee osallistaa kansalaisia ja valvoa heidän oikeusturvaansa sekä toimia avoimesti ja valvonnan alaisena.

Pohjoismaisesta mallista voidaan puhua myös oikeudellisesta näkökulmasta. Pohjoismaista oikeusjärjestelmää pidetään usein omana oikeusperheenään (mannereurooppalaisen) civil law -oikeuden ja (angloamerikkalaisen) common law -oikeuden rinnalla. Sille on ominaista, että oikeussäännöt ilmaistaan ennemmin lainsäädännön kuin oikeuskäytännön kautta ilman, että lainsäädäntö on hyvin yksityiskohtaista tai koottu kaiken kattaviin lakikirjoihin, joissa yksittäiset ratkaisut pohjautuvat yleisiin periaatteisiin. Lain sisältöä syvennetään usein esitöiden selityksissä, joilla on suuri merkitys lain soveltamisessa erityisesti juuri lain hyväksymisen jälkeen. Pohjoismaissa on pragmaattinen oikeusjärjestelmä, jonka tavoitteena on löytää toteuttamiskelpoisia ja kohtuullisia ratkaisuja eri tapauksiin. 
Myös lainsäädäntötyössä voidaan puhua pohjoismaisesta mallista. Lakitekstien laatimisen tavoitteena on, että lain ymmärtävät kaikki, joita se koskee. Lainsäädännön valmistelupohjan on oltava laaja, ja siinä on hyödynnettävä alakohtaista asiantuntijaosaamista ja asiaan liittyviä sidosryhmiä sekä itse selvitystyön että lakiehdotuksen lausuntokierroksen aikana. Laajan tai monisyisen lainsäädäntötyön selvittämiseen nimetään usein erityisiä selvittäjiä tai valmistelvelin. Parlamentin tulee saada hallitukselta lisäperusteluja lakiesityksen esittämisen yhteydessä. Sillä tavoin taataan sekä ehdotuksen sisällön tarkoituksenmukaisuus että demokraattinen hyväksyttävyys.

\section{Pohjoismaisen mallin kysyntä}

Laajasta yhteiskuntanäkökulmasta pohjoismainen malli on esimerkki siitä, kuinka demokratiaa, oikeusvaltiota ja perustavia ihmisoikeuksia voidaan vaalia. Voidaan sanoa, että pohjoismainen malli on syntynyt yhteiskunnassa, jolle on leimallista kansalaisten keskinäinen luottamus ja heidän luottamuksensa julkisiin viranomaisiin. Malli muodostaa samalla pohjan tällaiselle luottamukselle.

Nämä arvot yhdistettynä korkeaan hyvinvointiin ja sosiaaliturvaan ovat kysyttyjä maailmassa. Pohjoismaiselle mallille on ominaista myös se, ettei sitä kannattele pelkästään minkään suurvallan valta-asema. Lisäksi se on osoittanut muuntautu- miskykynsä Pohjoismaiden välisten pienten erojen osalta. Näin ollen se voi toimia esimerkkinä, jota muut maat voivat harkita pyrkiessään samoihin tavoitteisiin.

Muvalla maailmassa onkin monin tavoin havaittavissa kasvavaa kiinnostusta pohjoismaisen mallin tarjoamiin mahdollisuuksiin. Kansainvälistyneessä maailmassa pohjoismaiseen malliin kohdistuu samalla paineita sopeutua malleihin ja ratkaisuihin, jotka eroavat Pohjoismaiden käsityksistä. Pohjoismaisen mallin monet erilaiset ominaisuudet ilmenevät lainsäädännön kautta. Tehokas pohjoismainen oikeusyhteistyö edistää mallin säilymistä ja vahvistaa sitä mahdollisesti Pohjolan ulkopuolisiakin maita kiinnostavana vaihtoehtona yhteiskuntaratkaisuille.

Tukholmassa vuonna 2011 pidetyssä 39. pohjoismaisessa lakimieskokouksessa Ruotsin suurlähettiläs, entinen ulkoministeri Jan Eliasson ehdotti pohjoismaisen yhteistyön käynnistämistä, mielellään pohjoismaisen laitoksen muodossa globaalin konfliktinratkaisun edistämiseksi. ${ }^{1}$ Se lisäisi tietoa ja välittäisi yhteiskuntajärjestelmän pohjoismaista mallia muiden maiden hyödyksi. Tällainen pohjoismainen yhteistyö voi omalta osaltaan vahvistaa mallia, lisätä sen tunnettuutta ja esitellä sitä huomionarvoisena esimerkkinä maille, jotka pohtivat yhteiskuntansa rakenteiden organisointia.

1. Ks. Tukholmassa 18.-19. elokuuta 2011 pidetyn 39. pohjoismaisen lakimieskokouksen asiakirjat, osa I, s. 34-37. 


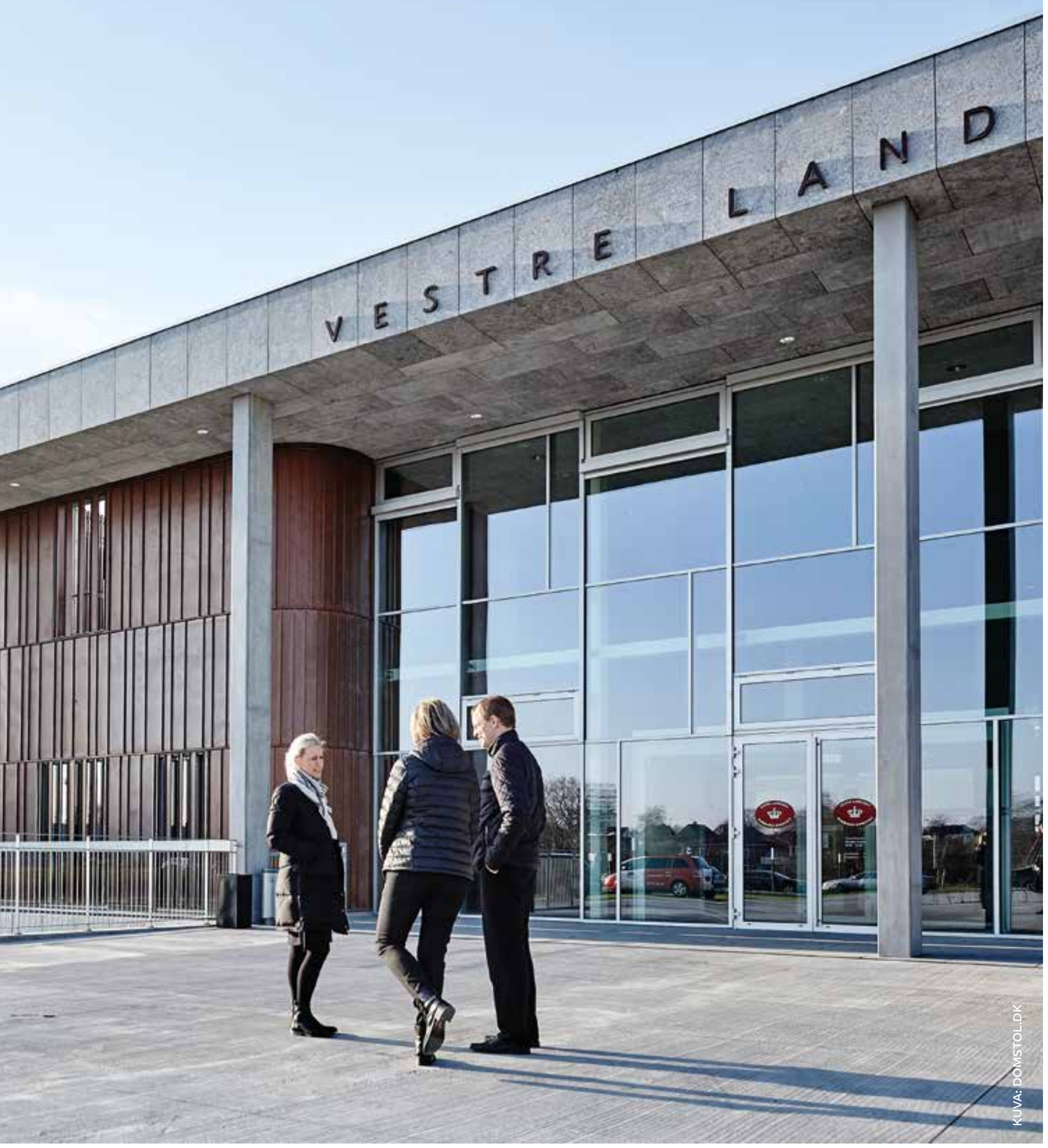




\section{Pohjoismainen oikeusyhteistyö - kehitys ja nykyiset yhteistyömuodot}

\section{Lähtötilanne ja yhtenäiset lait}

Pohjoismaisen oikeusyhteistyön katsotaan

käynnistyneen ensimmäisessä pohjoismaisessa lakimieskokouksessa vuonna 1872. Norjan ja Ruotsin unionin purkautumisen ja maailmansotien aikaisten taukojen jälkeen pohjoismaisia lakimieskokouksia on pidetty joka kolmas vuosi jonkin Pohjoismaan pääkaupungissa. Aluksi kokoukset olivat kohtaamispaikkoja merkittäville poliitikoille ja lakimiehille, jotka tekivät aloitteita yhteispohjoismaisista selvityksistä tavoitteena säätää lakeja ja uudistaa yksityisoikeutta tärkeiltä osin.

Työn seurauksena laadittiin yhteispohjoismaisia lakeja, jotka hyväksyttiin maiden parlamenteissa. Lakien rakenteet olivat samankaltaisia ja ne sisälsivät suurelta osin samoja sääntöjä yhtenäisesti muotoiltuna. Tämän ansiosta monet yksityishenkilöiden samoin kuin yritysten väliset oikeudelliset kysymykset ratkaistaan samalla tavalla eri puolilla Pohjolaa. Tällaisia yksityisoikeuden piiriin kuuluvia vekseleitä ja sekkejä sekä merenkulkua koskevia lakeja otettiin varhain käyttöön. 1900-luvulla laaditut yhteispohjoismaiset lait koskevat muun muassa kaupankäyntiä, sopimuksia, saatavien perintää (velkakirja), avioliiton solmimista ja purkamista ja aviopuolisoiden varallisuussuhdetta, lapsia ja vanhempia, henkilönimeä, osakeyhtiöitä, immateriaalioikeuksia, vahingonkorvausta ja kansalaisuutta. Yhteispohjoismaisia - muun muassa kaupankäyntiä ja merenkulkua koskevia - lakeja on myöhemmin tarkistettu useaan otteeseen pohjoismaisissa yhteyksissä.

\section{Yhteistyön muoto}

Oikeusyhteistyö on kuulunut pääasiassa maiden oikeusministeriöille, jotka ovat nimittäneet jäseniä yhteistyötä tekeviin pohjoismaisiin komiteoihin tai kansallisiin valmisteluelimiin. Selvitystyön tuloksena on laadittu sekä yhteispohjoismaisia että kansallisia selvityksiä, ja molemmissa yhteyksissä on usein laadittu lakiehdotuksia eri maille muotoiltuina rinnakkaisteksteinä. Selvityksiä on seurat- tu asiasta vastaavissa maiden ministeriöissä. Yleisen lausuntokierroksen jälkeen Pohjoismaiden ministeriöt ovat yleensä neuvotelleet keskenään ennen kuin lakiesitykset on esitelty parlamentille ja hyväksytty, tavallisesti vain pienin eroavuuksin maiden välillä. Joissakin tapauksissa yhteispohjoismainen lainsäädäntö perustuu pohjoismaiseen yleissopimukseen, jota yksittäiset maat ovat toteuttaneet omalla tavallaan kansallisessa lainsäädännössä.

Pohjoismaisilla laitoksilla on ollut rajattu asema tässä työssä. Joillakin aloilla oikeusyhteistyötä on kuitenkin käynnistetty Pohjoismaiden neuvoston aloitteesta tai suosituksesta.

\section{Pohjoismaisen yhteistyön yleissopimus - vuonna 1962 solmittu Helsingin sopimus}

Pohjoismaiden välisen oikeusyhteistyön periaatteet määritellään 23. maaliskuuta 1962 solmitussa Helsingin sopimuksessa (artiklat 2-7). Tavoitteet ovat korkeimmat yksityisoikeuden alalla, jossa yleissopimuksen mukaan maiden "on jatkettava lakiyhteistyötä mahdollisimman suuren yhdenmukaisuuden saavuttamiseksi yksityisoikeuden alalla" (artikla 4). Rikosoikeuden osalta sopimuksessa määrätään, että maiden "olisi pyrittävä yhdenmukaistamaan rikosta ja rikoksen seuraamuksia koskevat säännöksensä" (artikla 5). Lisäksi Pohjoismaiden "on pyrittävä muunkin kuin edellä mainitun lainsäädännön keskinäiseen yhtenäistämiseen sellaisilla aloilla, joilla tämä näyttää tarkoituksenmukaiselta" (artikla 6). Lisäksi jokaisen maan on varmistettava, että toisen Pohjoismaan tuomioistuimen tai muun viranomaisen päätös voidaan panna täytäntöön maan omien tuomioistuinten tai muiden viranomaisten päätösten mukaisesti (artikla 7).

Kulttuurialalla se toteutuu sääntöinä, jotka koskevat vastavuoroista opiskeluoikeutta korkea-asteen oppilaitoksissa, opintotukea ja ammattipätevyyksien vastavuoroista hyväksymistä (artiklat 9 ja 10). Sosiaalisessa yhteistyössä on puolestaan pyrittävä "säilyttämään ja edelleen kehittämään 
yhteisiä pohjoismaisia työmarkkinoita" ja "kansalliset työväensuojelua ja muita senlaatuisia kysymyksiä koskevat säännökset olisi pyrittävä yhdenmukaistamaan" (artikla 14). Maiden "on toimittava siihen suuntaan, että jonkin Pohjoismaan kansalainen oleskellessaan muussa Pohjoismaassa mahdollisimman laajalti pääsee osalliseksi oleskelumaan omille kansalaisilleen tarjoamista sosiaalisista eduista" (artikla 15). Ympäristönsuojelun alalla maat "pyrkivät mahdollisimman suuressa määrin sisäisessä lainsäädännössään ja sitä sovellettaessa samaistamaan muiden [maiden] ympäristönsuojeluedut oman maan etuihin" ja "pyrkivät yhdenmukaistamaan ympäristönsuojelusääntönsä saavuttaakseen mahdollisimman suuren yhtenäisyyden saasteiden päästöä, ympäristömyrkkyjen käyttöä ja muita ympäristöhäiriöitä koskevien säännösten ja ohjeiden osalta" (artiklat 30 ja 31). Helsingin sopimus sisältää siis myös oikeusyhteistyön ulkopuolisia säännöksiä, joiden pohjalta voidaan käynnistää pohjoismaista oikeustyötä. Lainsäädäntöyhteistyö voi lisäksi olla keino saada tuloksia yhteistyöstä Helsingin sopimuksen mukaisesti niiltä osin, kun sopimus ei suoraan viittaa oikeusyhteistyöhön.

Helsingin sopimuksen perusperiaatteena on, että Pohjoismaiden kansalaisia tulee kohdella yhdenvertaisesti. Kansalaisten yhdenvertaisesta kohtelusta voidaan poiketa vain, jos kansalaisuusvaatimus johtuu perustuslaista, kansainvälisistä velvoitteista tai jos se muista erityisistä syistä katsotaan tarpeelliseksi (artikla 2), ja maiden on lisäksi pyrittävä helpottamaan Pohjoismaiden kansalaisten kansalaisoikeuden saamista muussa Pohjoismaassa (artikla 3).

\section{Vuosi 1970 - oikeusyhteistyön käännekohta?}

Pohjoismaisen oikeusyhteistyön käännekohtana pidetään yleensä aikaa vuoden 1970 tienoilla. Yhteistyön pohja muuttui silloin kahdella tavalla.

Ensiksi myös perinteisillä oikeustieteen aloilla yleistyi ajattelutapa, että lainsäädäntö on poliittisten tavoitteiden toteuttamisen väline. Kun yhdessä maassa haluttiin käynnistää lainsäädän- tötoimia poliittisista syistä, prosessin aikataulua ja tavoitteita ei haluttu välttämättä suunnitella siten, että muutkin Pohjoismaat olisivat voineet osallistua siihen. Tämä tuli konkreettisesti esiin, kun Ruotsi halusi tarkistaa avioliiton solmimista ja purkamista koskevaa lainsäädäntöään, joka oli hyväksytty pohjoismaisen oikeusyhteistyön tuloksena - välittämättä siitä, oliko kyseinen tarkistus muiden Pohjoismaiden mielestä ajankohtainen juuri silloin.

Toinen muutos aktiivisen pohjoismaisen oikeusyhteistyön edellytyksiin oli Tanskan liittyminen Euroopan yhteisöön, nykyiseen Euroopan unioniin, vuonna 1972. Tanskan EY-jäsenyys rajoitti maan resursseja pohjoismaiseen oikeusyhteistyöhön samalla kun EY-säännöt saattoivat tehdä pohjoismaisesta koordinoinnista tai sääntelystä turhaa tai toisaalta estää tällaisen erityissääntelyn. Tämän jälkeen ei ole enää käynnistetty laajoja yhteispohjoismaisia lainsäädäntöhankkeita, vaikka työtä on jatkettukin jo käynnissä olleiden hankkeiden parissa (esimerkiksi uudet pohjoismaiset kauppalait).

\section{EU:n ja Etan merkitys}

Vuonna 1992 muut Pohjoismaat allekirjoittivat Eta-sopimuksen ja pääsivät osaksi Euroopan unionin sisämarkkinoita. Vuodesta 1995 lähtien Suomi ja Ruotsi ovat olleet EU-jäseniä ja Suomi liittyi euroalueeseen vuonna 1999. Tanska on aikoinaan neuvotellut itselleen varaumia muun muassa Euroopan unionin oikeus- ja talousyhteistyössä. Tanskan valtakuntaan kuuluvat Färsaaret ja Grönlanti eivät ole Euroopan unionin jäseniä. Islannilla ja Norjalla on puolestaan yhteyksiä EU-yhteistyöhön sisämarkkinoiden ulkopuolella etenkin Schengenin sopimuksen ja ulkomaalaisasioiden parissa tehtävän yhteistyön kautta. Kaiken kaikkiaan EU-oikeus on muodostanut 1990-luvun ensimmäiseltä puoliskolta lähtien keskeisen ja usein ratkaisevan perustan pohjoismaisen oikeusyhteistyön laajuudelle ja sisällölle. Se on edistänyt Pohjoismaiden lainsäädännön yhdenmukaistamista Helsingin sopimuksen mukaisesti - osana laajempaa 
eurooppalaista yhdenmukaistamista, mutta välillä hieman erisisältöisenä kuin jos yhdenmukaistaminen olisi tehty pelkästään Pohjoismaiden välillä.

\section{Pohjoismaisen oikeusyhteistyön nykyinen rakenne}

Alun perin pohjoismaista oikeusyhteistyötä tehtiin - poliittisen tason ja vähitellen Pohjoismaiden neuvoston lisäksi - Pohjoismaiden ministeriöiden, ennen kaikkea oikeusministeriöiden kautta. Oikeusyhteistyötä ohjailtiin pääasiassa ministeriötason pohjoismaisissa kokouksissa, joihin osallistui oikeuspäälliköitä, erityisedustajia tai yhteyshenkilöitä. Tietyillä aloilla oli pysyviä pohjoismaisia komiteoita (esimerkiksi pohjoismainen rikosoikeuskomitea). Pohjoismaiden ministerineuvosto perustettiin vuonna 1972, ja siitä lähtien sen alaiset virkamieskomiteat ovat korvanneet oikeuspäälliköiden kokoukset. Pysyvistä komiteoista on tullut torkkuvia, ja sihteeristötehtävät ovat vähitellen siirtyneet ministerineuvoston sihteeristölle, joka avustaa puheenjohtajamaata ministerikokousten ja virkamieskomiteoiden kokousten valmistelussa ja seurannassa. Koska puheenjohtajuus vaihtuu vuosittain maiden välillä, ministerineuvoston sihteeristö voi edistää työn parempaa jatkuvuutta.

Virkamieskomiteat - joihin osallistuu virallisesti yksi jäsen ja yksi varajäsen jokaisesta maasta kokoontuvat yleensä kolme-neljä kertaa vuodessa. Komiteoiden osallistuminen oikeusyhteistyöhön vaihtelee etenkin jäsenten asiantuntijakokemuksen pohjalta. Siihen vaikuttaa myös, miten paljon jäsenillä on muita tehtäviä pohjoismaisten ministerikokousten valmistelun lisäksi. Monet virkamieskomiteat keskittyvät muihin kuin oikeusyhteistyön asioihin. Oikeusyhteistyötä käsittelevien virkamieskomiteoiden työssä on kuitenkin alettu keskittyä vähemmän varsinaisiin lainsäädäntöhankkeisiin. Ne ovat sen sijaan järjestäneet usein pohjoismaisia seminaareja ajankohtaisista asioista tavoitteena luoda pohjaa maiden lainsäädännölle tai nykyisen lainsäädännön toimeenpanolle. Virkamieskomiteat ovat käynnistäneet muutamia pohjoismaisia selvityksiä yleensä rajatuista aiheista. Niihin on saatu rahoitusta joko kokonaan tai osittain ministerineuvoston budjetista. Seminaariraportteja ja selvityksiä on julkaistu painettuina ministerineuvoston julkaisusarjoissa. Raporttien ja selvitysten seuranta näkyy hyvin vaihtelevissa määrin virkamieskomiteoiden työssä ja Pohjoismaiden lainsäädännössä.

Tietyillä aloilla pohjoismaista yhteistyötä tehdään ministeriöiden välisissä suorissa yhteyksissä ilman Pohjoismaiden ministerineuvoston tai sen alaisen virkamieskomitean osallistumista työhön. Se voi olla seurausta virkamieskomitean lakkauttamisesta.

Pohjoismaista oikeusyhteistyötä ei ole koskaan tehty Pohjoismaiden parlamenttien välisenä suorana yhteistyönä. Oikeusyhteistyön alkuaikoina nimekkäät poliitikot, jotka olivat juristeja, kokoontuivat pohjoismaisiin lakimieskokouksiin. Myöhemmin kokouspaikkana alkoi toimia Pohjoismaiden neuvosto.

\section{Pohjoismaiden neuvosto ja Pohjoismaiden ministerineuvosto}

Nykyään poliittisen tason pohjoismainen oikeusyhteistyö vaikuttaa toimivan enimmäkseen Pohjoismaiden neuvoston jäsenten yksittäisten aloitteiden kautta. Aloitteiden perusteellinen jalkauttaminen ja niiden selkeä kytkös lainsäädäntöön vaihtelee, ja aloitteiden tavoitteena ei yleensä nykyään olekaan laajoja alveita kattava uusi lainsäädäntö. Pohjoismaiden neuvoston istunnoissa tehtyihin päätöksiin - suosituksiin ja esityksiin - vastaa joko Pohjoismaiden ministerineuvosto (ajankohtaisen ministerineuvoston ministerit) tai maiden hallitukset maan tekemän arvion pohjalta. Vastaus valmistellaan usein kyseisessä virkamieskomiteassa. Poliittisella tasolla seurantaa saatetaan usein pitää rajallisena ja aikaa vievänä.

\section{Virkakoneiston asema}

Pohjoismaisen oikeusyhteistyön toteutus riippuu suurelta osin virkakoneistosta etenkin alakohtaisissa ministeriöissä. Ne kokevat pohjoismaista oikeusyhteistyötä koskevan tiedon ja kokemusten vaihdon hyödylliseksi. Muiden Pohjoismaiden 
yhteyshenkilöt mahdollistavat keskustelut ajankohtaisista lainsäädäntöasioista samoista asioista kiinnostuneiden kollegoiden kanssa. Tietyillä aloilla pohjoismaisten virkamiesten yhteydenpito voi olla tiivistäkin. Tehtävämäärän, etenkin eurooppalaisten ja muiden kansainvälisten velvoitteiden, ja työllisyystilanteen takia on kuitenkin vaikeaa löytää aikaa ja resursseja pohjoismaiseen oikeusyhteistyöhön. Virkamiehet ovatkin yleisesti sitä mieltä, etteivät suuret pohjoismaiset lainsäädäntöhankkeet tai Pohjoismaiden lainsäädännön laajat yhdenmukaistamishankkeet ole realistisia muiden kansainvälisten velvoitteiden lisäksi.

\section{Etujärjestöjen ja tutkijoiden pohjoismainen yhteistyö}

Etujärjestöt, etenkin työelämän pääjärjestöt, saattavat tehdä tiivistä yhteistyötä muiden

Pohjoismaiden sisarjärjestöjen kanssa. Yhteistyön seurauksena tehdään usein yhteisiä aloitteita kansainvälisillä areenoilla, etenkin EU-komissiossa. Etujärjestöt suhtautuvat hyvin myönteisesti pohjoismaiseen oikeusyhteistyöhön, joka voi edistää niiden etua. Ne pitävät sen takia sääntöjen pohjoismaista yhdenmukaistamista usein myönteisenä. Etenkin elinkeinoelämän järjestöt saattavat puolestaan suhtautua kriittisesti pohjoismaisiin erityissääntöihin, jotka menevät eurooppalaisia velvoitteita pidemmälle.

Virkakoneiston ulkopuoliset - erityisesti akateemisen maailman - alan toimijat kokevat pohjoismaisen oikeusyhteistyön aiempaa näkymättömämmäksi. Oikeustieteellinen tutkimus on kansainvälistynyt, ja Eurooppaoikeus on keskeisellä sijalla osittain pohjoismaisen näkökulman kustannuksella. Monilla aloilla on kuitenkin merkittäviä pohjoismaisia oikeustieteen tutkijoiden välisiä yhteysverkostoja ja esimerkiksi pohjoismaisia yhdistyksiä, konferensseja ja lehtiä. Oikeustieteen tutkijat eivät kuitenkaan osallistu pohjoismaiseen oikeusyhteistyöhön yhtä suoraan kuin aiemmin. Lisäksi oikeustieteen tutkijoiden odotetaan hankkivan entistä enemmän ulkoista rahoitusta tutkimuslaitoksen talouden vahvistamiseksi, ja rahoitusta haetaan usein eurooppalaiselta tasolta.

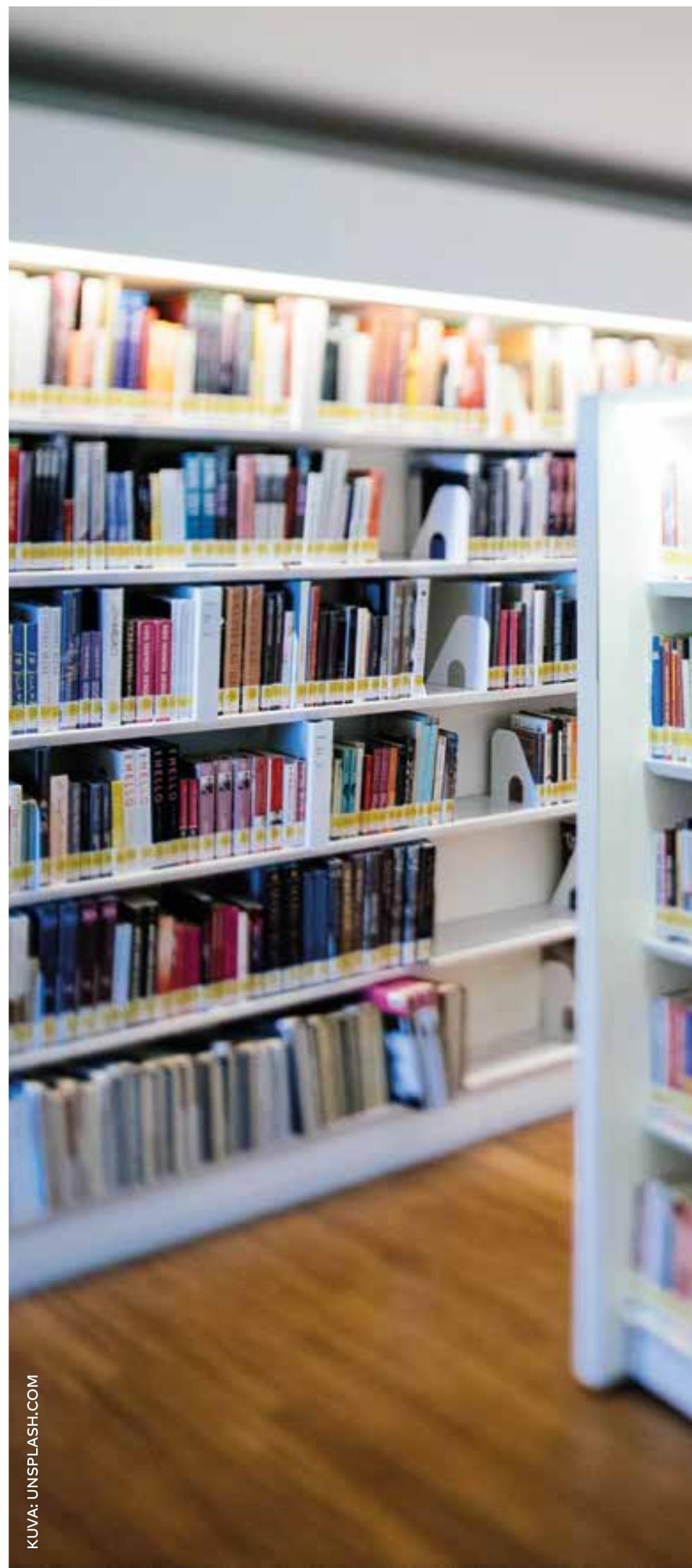




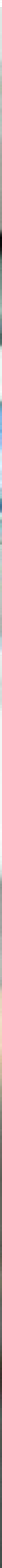



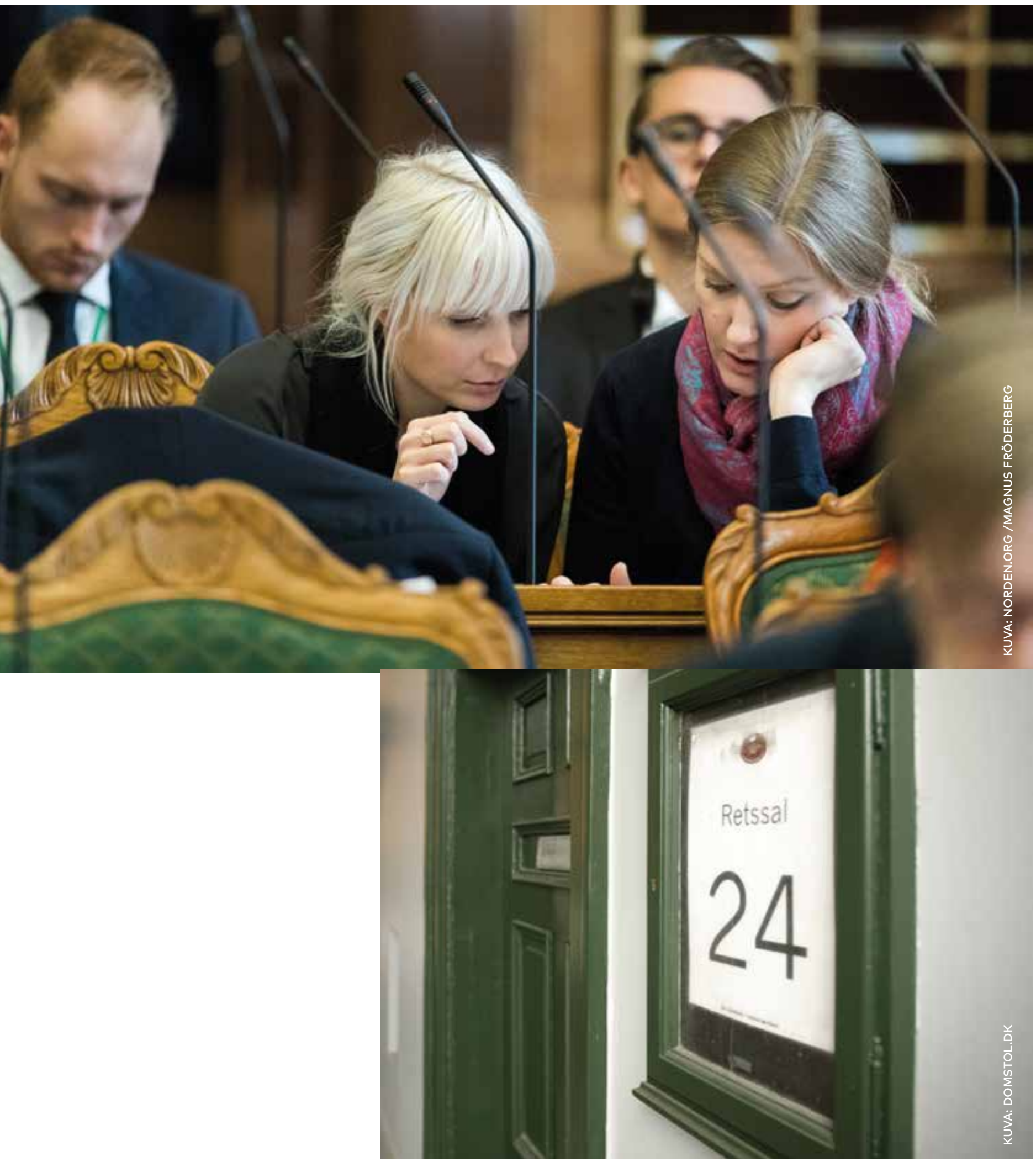


\section{Mikä edistää tai estää nykyistä pohjoismaista oikeusyhteistyötä?}

Monilla aloilla on pitkä kokemus pohjoismaisesta oikeusyhteistyöstä etenkin oikeusministeriön perinteisillä vastuualueilla. Tämä kokemus voi innostaa oikeusyhteistyön jatkamiseen. Tähänastisesta työstä voidaan toisaalta ajatella, että yhteispohjoismaisen lainsäädännön tarve on nyt pitkälti täytetty. Pohjoismaiden välisten "rajaesteiden" ja lisääntyneen liikkuvuuden tiedostamisen myötä havaitaan kuitenkin uusia tarpeita.

\section{Eurooppalainen konteksti}

Helsingin sopimus solmittiin vuonna 1962 monen Pohjoismaan haettua silloisen ETYn jäsenyyttä, ja se merkitsi pohjoismaisen yhteistyön virallistamista. Pohjoismaiden nykyiset EU-yhteydet, kahden maan osalta Eta-sopimuksen kautta, linjaavat pohjoismaista yhteistyötä. Niiden tai maiden erilaisten EU-yhteyksien ei kuitenkaan tarvitse muodostaa esteitä yhteistyölle. Pohjoismaisten jäsenvaltioiden on havaittu korostavan, että on tärkeää esiintyä "hyvänä eurooppalaisena" eikä muodostaa "pohjoismaista blokkia" jäsenyyden myötä. Nykyään tämä ei kuitenkaan sido maita yhtä paljon. Euroopan unionin kehitys voi antaa enemmän tilaa erilaisille yhteistyömuodoille ja yhdenmukaistamisen tasoille, ja pohjoismainen oikeusyhteistyö voi luoda entistä syvemmän yhteistyön malleja ja esimerkkejä, joita Euroopan unioni voi sopivissa olosuhteissa harkita Euroopan yhtenäistymisen vahvistamiseksi. Esimerkkinä voidaan mainita pohjoismaista pidätysmääräystä koskeva lainsäädäntö, joka on kehitetty eurooppalaista pidätysmääräystä koskevien EU-sääntöjen pohjalta.

Euroopan unioni osallistuu jäsenmaidensa kautta kansainvälisiin neuvotteluihin, joissa sillä on sopimuksentekovalta. Se rajoittaa kaikkien viiden Pohjoismaan tekemän yhteistyön mahdollisuuksia tällaisissa sopimusneuvotteluissa.

\section{Poliittisen sitoutumisen merkitys}

Pohjoismaista oikeusyhteistyötä voidaan edistää joko täysin ideologiselta kannalta tai poliittisen tuen pohjalta. Ideologista skandinavismia esiintyi etenkin 1800-luvun loppupuoliskolla. Poliittista tukea voidaan saada sekä kansallisesti että pohjoismaisella tasolla erityisesti Pohjoismaiden neuvoston ja Pohjoismaiden ministerineuvoston kautta. Poliittinen tuki voi olla yleistä, mutta yksittäisissä tapauksissa sillä on luultavasti sitä enemmän vaikutusvaltaa mitä konkreettisempaa se on.

Eurooppaoikeus ja muut kansainväliset velvoitteet rajoittavat kansallista poliittista toimintavaltaa aiempaa enemmän. Onko maissa sitten poliittista tahtoa rajoittaa kansallista poliittista toimintavaltaa entisestään pohjoismaisen yhteistyön kautta?

Aitoon pohjoismaiseen yhteistyöhön kuuluu, että kansalliset poliitikot jossain määrin pidättyvät tekemästä täysin kansallisia ehdotuksia, jotka ovat ristiriidassa Pohjoismaiden yhteisten ratkaisuiden kanssa. Lisäksi pohjoismaisen yhteistyön puitteissa tehtyjä lainsäädäntöehdotuksia seurataan myös pohjoismaisella tasolla, ei pelkästään kansallisella tasolla, jossa puhtaasti kansallisten aloitteiden käsittely voi tuoda poliittista hyötyä.

Kansallisten aloitteiden ja pohjoismaisen yhteistyön välillä ei tarvitse kuitenkaan olla ristiriitaa. Täysin kansalliset aloitteet saattavat hyvin soveltua käsiteltäviksi Pohjoismaiden neuvostossa tai Pohjoismaiden ministerineuvostossa. Esimerkki siitä on ehdotus ehdottoman 18 vuoden ikärajan asettamisesta avioliiton solmimiselle.

Poliitikot suhtautuvat eri tavoin pohjoismaiseen yhteistyöhön ja priorisoivat sitä vaihtelevasti. Se saattaa vaikuttaa ministerineuvostojen päätöksiin, koska niissä on ollut tapana pyrkiä yhteistyötoimia koskevaan yksimielisyyteen. Tämä tarkoittaa sitä, että asiaan kaikista varautuneimmin suhtautuvan maan kanta ratkaisee ja enemmistön kannattamista asioista joudutaan kuitenkin luopumaan. Tämä voidaan välttää, jos yhteistyötoimiin voidaan sen sijaan ryhtyä kahden tai useamman Pohjoismaan kesken ilman, että kaikkien maiden tarvitsee olla mukana. Näin laadittavista selvityksistä ja saatavista kokemuksista voi kuitenkin olla hyötyä kaikille myöhemmässä vaiheessa. 


\section{Kansallisen vastuunjaon merkitys}

Ministereiden ja ministeriöiden vastuvalueet vaihtelevat jossain määrin maiden välillä. Pohjoismainen yhteistyötoimi voi sen vuoksi kuulua eri ministereiden vastuulle eri maissa. Vaikka asia kuuluu eri ministeriöille, sen ei havaintojen mukaan välttämättä tarvitse muodostaa estettä virkamiestason jatkuvalle yhteistyölle. Asialla voi tosin olla merkitystä ministeritasolla, jos kaikki asiasta vastaavat ministerit eivät kuulu asianomaiseen ministerineuvostoon. Jos asia on yhden tai kahden ministerin vastuvalueen ulkopuolella, ministerineuvostolla ei ehkä ole poliittista tahtoa ottaa asioita esille. Sen ei kuitenkaan tarvitse estää yhteistyötoimia, mikäli hyväksytään, että kaikki maat eivät osallistu ministerineuvoston käynnistämiin aloitteisiin. Sellaisissa tapauksissa voi olla erityisen tärkeää, että asialle on selvä tilaus Pohjoismaiden neuvostolta.

\section{Yhteispohjoismainen asialista ja julkinen tila?}

Pohjoismainen oikeusyhteistyö luonnistuu helpommin asioissa, jotka ovat samanaikaisesti Pohjoismaiden omilla asialistoilla. Ajankohtaisuus voi myös herättää poliittista kiinnostusta eri puolilla Pohjoismaita ja helpottaa hallinnollisten resurssien varaamista lainvalmisteluun. Lainsäädäntöasiat ovat kuitenkin vaihtelevasti esillä samaan aikaan kaikissa Pohjoismaissa.

Uusien EU-säädösten täytäntöönpano käynnistyy samanaikaisesti, vaikka ne sisällytetäänkin Eta-sopimukseen usein vasta myöhemmässä vaiheessa. Maiden täytäntöönpanon aikataulut ovat yleensä hyvin tiukkoja. Neuvoteltaessa muita uusia kansainvälisoikeudellisia yleissopimuksia ratifiointi ja sisällyttäminen kansallisen lainsäädäntöön tapahtuu likimain samaan aikaan Pohjoismaissa, eikä aikataulu välttämättä ole yhtä tiukka kuin EU- tai Eta-säädösten täytäntöönpanossa.

Lisäksi kansainvälisen tai teknologisen kehityksen myötä uutta lainsäädäntöä koskeva kysymys voi nousta esiin samaan aikaan kaikissa Pohjoismaissa. Toisaalta maan sisäiset tapahtumat ja yhteiskuntakehitys voivat johtaa siihen, ettei näin käy. Siihen voivat myös vaikuttaa maiden erilaiset poliittiset priorisoinnit. Vaaleissa kulloinkin menestystä niittäneen valtionjohdon poliittiset suuntaukset voivat vaihdella maiden välillä, ja eri puolvevärit voivat johtaa erilaisiin lainsäädäntötoimien toteuttamista koskeviin priorisointeihin.

Pohjoismaiselle oikeusyhteistyölle voi myös olla haitaksi, ettei meillä oikeastaan ole yhteispohjoismaista julkista tilaa. Yhteiskuntakeskustelua käydään pääasiassa erikseen kussakin Pohjoismaassa, vaikka tiettyä päällekkäisyyttä saattaa esiintyä maiden välillä enemmän kuin Pohjoismaiden ulkopuolisten maiden kanssa.

\section{Tehtävien luonne}

Joistakin oikeuden aloista, joita aiemmin pidettiin "ei-poliittisina" ja jotka pitkälti jätettiin oikeustieteen asiantuntijoiden vastuulle lainvalmistelussa, on nykyään tullut hyvinkin polttavia poliittisia aiheita. Tyypillisiä esimerkkejä tästä ovat perheja rikoslainsäädäntö. Muilla aloilla pohjoismainen sopeuttaminen tai yhdenmukaistaminen voi kohdata vaikeuksia, koska siitä on suuria hallinnollisia tai taloudellisia seurauksia jollekin maalle. Tämä pätee erityisesti silloin, kun lainsäädännöllä on kytkös hallinnon tai talouden perusrakenteisiin.

\section{Lainsäädäntöprosessiin kohdistuvat odotukset}

Nykyään lainsäädäntöprosessin edellytetään yleensä olevan entistä nopeampi ja antavan poliittisia tuloksia ennen seuraavia parlamenttivaaleja aloitteen tehneen hallituksen eduksi. Koska tavalliset nelivuotiset vaalikaudet käynnistyvät eri aikoihin eri maissa, joidenkin maiden hallituksille jää muita maita vähemmän aikaa tulosten aikaansaamiseen. Se miten paljon tämä vaikuttaa haluun käynnistää pohjoismaista yhteistyötä, voi riippua kyseisen alan poliittisesta ajankohtaisuudesta. 
Lainsäädäntötyö on yleisen käsityksen mukaan nopeutunut merkittävästi Pohjoismaissa viimeisten vuosikymmenten aikana. Syinä ovat yleinen yhteiskunta- ja mediakehitys sekä uusien EU- ja Eta-sääntöjen toimeenpanon erityiset aikataulut. On epäselvää, onko ministeriöiden lainvalmisteluresursseja sopeutettu lainsäädännön tarpeisiin. Ainakin pohjoismaisissa EU-jäsenmaissa koetaan, että ministeriön resursseja joudutaan usein käyttämään EU-säännöstön valmisteluun kansallisen lainsäädännön valmistelun kustannuksella.

Kansallisella tasolla monet lakiesitykset näyttävät pohjautuvan ministeriöiden selvityksiin sen sijaan, että laajemman kokoonpanon valmisteluelin olisi tarkastellut asiaa. Pohjoismaisen yhteistyön organisointi ja toteutus vie helposti enemmän aikaa kuin puhtaasti kansallinen lainvalmistelu. Mikäli selvitykseen tarvitaan eri sidosryhmiä, pohjoismaisesta selvityksestä voi tulla niin laaja, että se itsessään hidastuttaa työtä. Tällaiselta ongelmalta voidaan välttyä, mikäli lainvalmistelun selvitystyö on tarkoituksenmukaista toteuttaa yhden selvityshenkilön voimin.

Aikapaine ja resurssien puute voivat käytännössä hankaloittaa tai estää pohjoismaista oikeusyhteistyötä. Näin voi käydä asiaa käsittelevässä ministeriössä, joka valmistelee hallituksen lakiesitystä parlamentille. Jos maat ovat tietyn alan lainsäädäntöprosessin eri vaiheissa, niiden voi olla vaikeaa varata samanaikaisesti aikaa ja resursseja alan yhteistyöhön. Pohjoismainen oikeusyhteistyö voi siinä tapauksessa merkitä työnjakoa, josta saadaan resursseja maiden lainsäädäntötyön helpottamiseksi. Tämä koskee Islantia, Färsaaria ja Grönlantia, joilla on vähemmän resursseja lainvalmisteluun, ja tietyissä tilanteissa myös muita Pohjoismaita. Se edellyttää kuitenkin, että pohjoismainen yhteistyö on hyvin organisoitua ja sopeutettua maiden aikatauluihin etenkin EU-lainsäädännön toteuttamisessa.

Pohjoismaisen selvitystyön myötä voidaan myös saada asiantuntemusta, jota ei ole saatavilla yksittäisissä maissa. Tämä oli näkyvä piirre oikeusyhteistyön alkuvaiheessa ja yleisen käsityksen mukaan se paransi maiden lainsäädännön laatua.

\section{Kielen kehitys Pohjoismaissa}

Kielen kehitys vaikuttaa lisäävän Pohjoismaiden kielten välistä etäisyyttä. Monesti sanotaan, että skandinaavisten naapurikielten eli norjan, ruotsin ja tanskan vastavuoroinen ymmärtäminen on heikentynyt viimeisten vuosikymmenten aikana. Erityisesti tämä koskee puhuttua kieltä. Skandinaavisten kielten merkitys on myös vähentynyt Suomessa ja Islannissa. Skandinaavista kieltä äidinkielenään puhuva ei puolestaan ymmärrä suomea tai islantia, ja sekä Suomen että Islannin kielenopetuksessa ja koulutuksessa on viime vuosina keskitytty enemmän maailman kieliin (etenkin englantiin) kuin skandinaavisiin kieliin. Toisaalta Pohjoismaiden rajat ylittävä liikkuvuus on lisääntynyt, mikä voi osaltaan edistää parempaa kielten ymmärtämistä.

Pohjoismaisessa oikeusyhteistyössä on perinteisesti käytetty skandinaavisia kieliä. Viestintä on helpompaa, kun osallistujat voivat käyttää omaa äidinkieltään ja muut ymmärtävät heitä. Tällainen yhteinen kielellinen pohja on tärkeä laadittaessa lakiehdotuksia, joita on tarkoitus seurata maissa. Oikeudelliset käsitteet ovat pitkälti samoja Pohjoismaissa, vaikka norjan, ruotsin ja tanskan ilmauksissa voikin olla eroja. Yhteistyötä voi vaikeuttaa, mikäli siihen osallistuvat virkamiehet ja asiantuntijat eivät hallitse skandinaavisia kieliä tarpeeksi hyvin.

Sama koskee lakimiehiä, joilla on erityisasema pohjoismaisessa oikeustyössä. Oikeustieteen kirjallisuuden määrä eri Pohjoismaissa on kasvanut ja kansainvälistyminen lisääntynyt eurooppalaistumisen ja globalisaation muodossa, minkä takia oikeustiedettä opiskelevat ja työelämässä toimivat juristit luultavasti lukevat vähemmän alan kirjallisuutta (muilla) skandinaavisilla kielillä. Seurauk- 
sena voi olla, että pohjoismainen oikeusyhteistyö koetaan aiempaa raskaammaksi, mikä voi estää pohjoismaisen oikeusyhteistyön käynnistämistä uusien kysymysten parissa.

Käytännössä skandinaavisten kielten vaihtoehtona on englanti, ja sen osaaminen onkin vahvistunut yleisesti kaikissa Pohjoismaissa. Englanninkielinen oikeusterminologia ja käsitteistö eroavat kuitenkin huomattavasti pohjoismaisesta oikeudesta. Yhteistyössä, joka ei tähtää konkreettisiin lakiehdotuksiin ja jonka aiheena ovat ennemmin ajankohtaiset yhteiskunnalliset ongelmat kuin oikeudelliset kysymykset, on helpompi käyttää englantia. Tämä koskee erityisesti yhteistyötä, jonka tavoitteena ovat pohjoismaiset aloitteet EU-neuvotteluissa tai kansainvälisillä foorumeilla.

\section{Poliittisia aloitteita oikeusyhteistyöhön?}

Laajat poliittiset lainsäädäntöaloitteet ovat nykyään harvinaisia pohjoismaisessa oikeusyhteistyössä. Pohjoismaiden ministerineuvoston alaisten virkamieskomiteoiden yhteistyössä keskitytään usein hankkeisiin ja toimiin, joilla ei ole suoraa yhteyttä lainsäädäntöön. Tämä voi vaikuttaa ristiriitaiselta, koska oikeudellistuminen on ollut näkyvä kehityssuuntaus viime vuosina.

Siinä määrin kun pohjoismaisen yhteistyön poliittiset aloitteet riippuvat ministeriöiden ideoista, niiden saaminen hankaloituu usein käytännössä, koska ne merkitsevät lisätyötä virkamiesten jo entisestään tiukassa työtilanteessa. Työtilanne voi myös vaikuttaa siihen, miten virkamieskomiteat suhtautuvat uusiin aloitteisiin.

\section{Ministeriöiden asema}

Pohjoismaisen oikeusyhteistyön organisointi ja toteutus helpottuu, kun ministeriöiden virkamiehet tuntevat toisensa hyvin ja kyseisellä asiantuntijaalalla on hyvät yhteydet Pohjoismaissa. Oikeudenala voi kuulua eri ministeriöiden alaisuuteen eri maissa, mikä hankaloittaa keskustelun syntymistä virkamieskomiteoissa, joissa joka maasta on vain yhden ministeriön edustajia. Sen ei kuitenkaan tarvitse vaikeuttaa henkilöiden välistä yhteydenpitoa, mutta niin voi käydä yhteisten työryhmien kokoamisessa. Virkamiesten jatkuva vaihtuvuus voi olla yhteistyön esteenä, kun taas pohjoismaisen virkamiesvaihdon aktiivinen hyödyntäminen voi edistää sitä. Tietyn alan pohjoismaisen oikeusyhteistyön käynnistäminen voi olla helpompaa, jos alan asiantuntijaympäristöillä on hyvät pohjoismaiset yhteydet.

Virkamieskomiteoiden työtä on leimannut ainakin osittain suuri jatkuvuus. Se voi helpottaa yhteistyötä mutta toisaalta vaarana on yhteistyön jähmettyminen etenkin, jos jäsenet pyrkivät suojelemaan omia ministeriöitään uusilta työtehtäviltä viitaten siihen, mitä on realistista toteuttaa.

Pohjoismaisessa oikeusyhteistyössä ministeriötason resursseilla on keskeinen merkitys, sillä ministeriöt vastaavat lakiesitysten valmistelusta ennen niiden esittelyä maan parlamentille hyväksymistä varten. Pohjoismainen työ joutuu käytännössä kilpailemaan resursseista muiden ministeriölle kuuluvien - niin kansallisten, eurooppalaisten kuin kansainvälisten - tehtävien kanssa. Suurempi panostus pohjoismaiseen oikeusyhteistyöhön voi sen vuoksi edellyttää vahvempaa poliittista priorisointia tai sitä, että pohjoismainen oikeusyhteistyö voi yksinkertaistaa tai helpottaa ministeriön työtä asian parissa. 


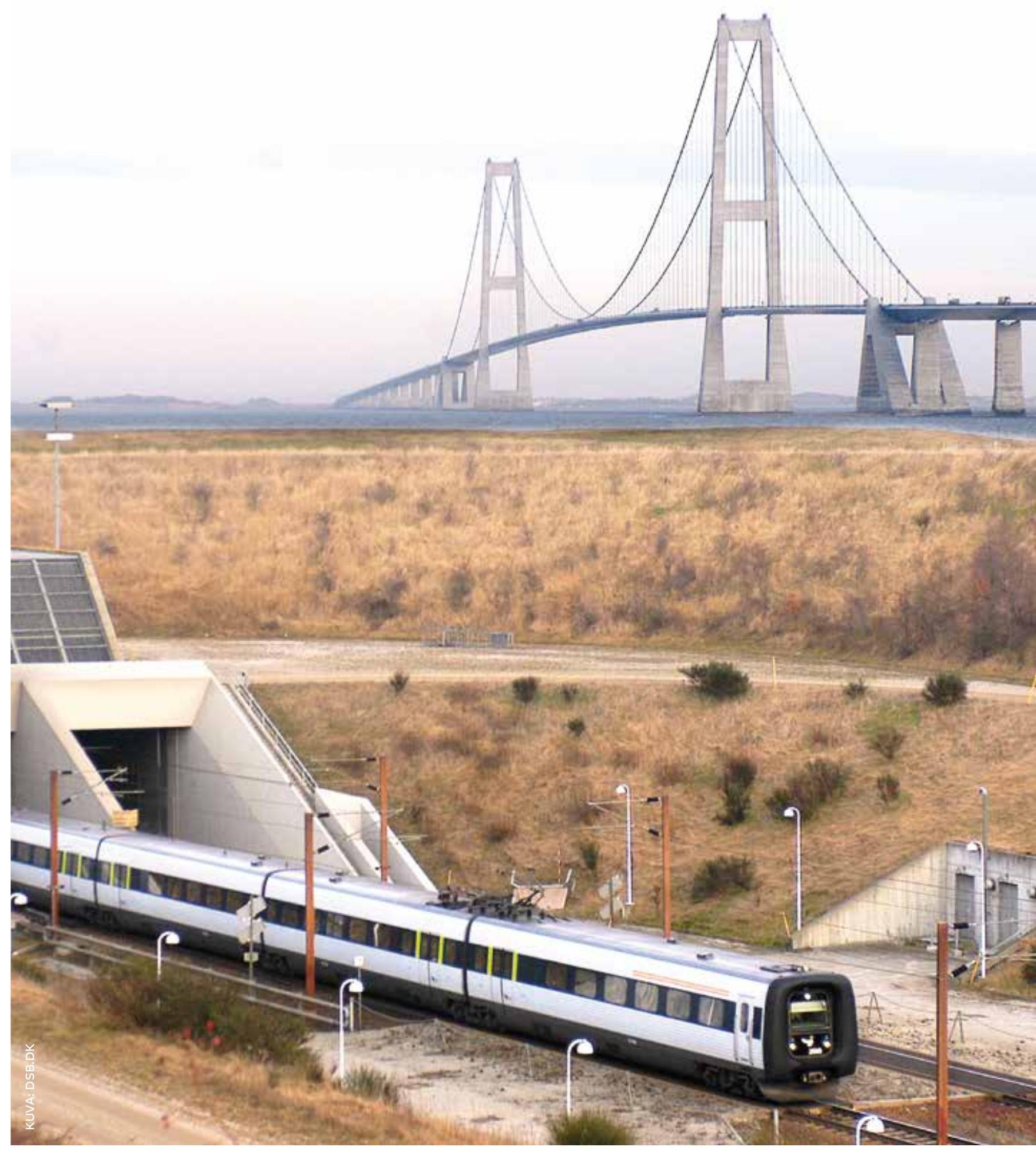




\section{Pohjoismaisen oikeusyhteistyön tavoitetaso}

Pohjoismaisen oikeusyhteistyön tavoitetaso vaihtelee. Tavoitetasossa voi olla eroja aihealueiden välillä ja sitä voidaan sopeuttaa yksittäisten asioiden ja niihin liittyvien tarpeiden mukaan.

Moni voi olla sitä mieltä, että tavoitetaso on vaihdellut ajan mittaan. Tavoitetason muuttuminen tulosten saamisen osalta voi kuitenkin johtua yhteistyön edellytysten vaihtelusta ja niihin sopeutumisesta.

Tavoitetaso voi vaihdella myös sen mukaan, onko tiettyä asiaa koskevassa yhteistyössä mukana enemmän vai vähemmän maita. Pohjoismaisen yhteistyön tavoitteena on perinteisesti ollut se, että kaikki maat osallistuvat siihen tasavertaisina sillä varauksella, että maa on voinut joutua perumaan osallistumisensa tai rajoittamaan sitä resurssisyistä. Tämä perinteinen tavoite johtaa kuitenkin helposti siihen, että jos kaikkien maiden välillä ei ole yksimielisyyttä pohjoismaisen yhteistyöhankkeen aloittamisesta, yhteistyöstä irtisanoudutaan kokonaan. Sen vuoksi vaihtoehtona onkin, että yksittäisten asioiden parissa tehtäväön pohjoismaiseen oikeusyhteistyöhön osallistuu vain joitakin maita.

\section{Yhtenäinen pohjoismainen lainsäädäntö}

Suurimpana tavoitteena on yhtenäinen (yhdenmukainen) lainsäädäntö, jolla Pohjoismaiden lainsäädännön yhtenäisyys saadaan aikaiseksi. Tavoitetason perustana voi olla se, että Pohjoismaiden lainsäädännön yhtenäisyyttä pidetään omana arvonaan tai että "pohjoismaiseksi hyödyksi" koetaan se, että yhteisillä säännöillä poistetaan erilaisten sääntöjen mahdollisesti aiheuttamia rajaesteitä.

Kun lainsäädännöstä saadaan täysin yhtenäinen, samansisältöiset lait hyväksytään eri maissa. Yksi kieliversio ei päde kaikissa maissa. Koska kielten välillä on eroja ja pohjoismaisen yhteistyön puitteissa hyväksyttyä lakia voi olla välttämätöntä tulkita maan muun lainsäädännön valossa, lainsäädäntötilanteessa voi syntyä vivahde-eroja samansisältöistenkin lakien kohdalla.

Yhtenäinen lainsäädäntö voi olla ajankohtainen sekä asioissa, joissa Pohjoismaat voivat vapaasti valita lainsäädäntöratkaisunsa, että kansainvälisten yleissopimusten ja sopimusten edellyttämissä asioissa.

Yhtenäinen lainsäädäntö ei välttämättä tarkoita lainsäädännön täyttä yhtenäisyyttä kaikissa kysymyksissä. Pohjoismaiden erilaisten tilanteiden ja arvojen takia asioita voidaan ratkaista eri tavoin yhteisen säödöskehyksen puitteissa.

Lain - lakirakenteen - yhteisestä laadinnasta saadaan useita maiden rajat ylittäviä etuja. Mikäli tietyn alan laki on laadittu samaan tapaan kaikissa Pohjoismaissa, asiaa koskevat säännökset ovat helpommin löydettävissä toisessa Pohjoismaassa. Jos lain rakenne on sama eri maissa, tarpeettomat erot ovat helpommin havaittavissa ja mahdollisesti poistettavissa. Mikäli lakeihin tarvitaan myöhemmin muutoksia uusien EU- tai Eta-sääntöjen tai muiden kansainvälisten velvoitteiden seurauksena, se voi onnistua helpommin yhteisen lakirakenteen pohjalta.

\section{Koordinoitu lainsäädäntö vai sitovat yleissopimukset?}

Yhteispohjoismaisiin sääntöihin liittyvää pohjoismaista yhteistyötä on tehty suurelta osin kansallista lainsäädäntöä silmällä pitäen. Se tapahtuu joko laatimalla rinnakkaisia lakitekstejä pohjoismaisen yhteistyön puitteissa tai ottamalla kantaa laadittavan lain sisältöön, minkä jälkeen maat saavat laatia omat lakinsa siltä pohjalta. Tämä yhteistyömuoto ei sido maita kansainvälisoikeudellisesti, ja kaiken kaikkiaan se on yksinkertaisempi toimintatapa kuin jos maiden pitäisi ensin päästä yksimielisyyteen yleissopimuksesta, joka sitten toteutetaan kaikkien maiden lainsäädännössä. Toimintatapa ei myöskään aiheuta ongelmia Euroopan unionin perussopimuksen suhteen. 
Yhtenäistä lainsäädäntöä tarvitaan erityisesti rajat ylittävässä toiminnassa. Tämä toive voidaan toteuttaa - vaikka työtä on vielä jäljellä - selventävillä säännöillä siitä, minkä maan viranomaisten tulee käsitellä asiaa (lainkäyttövalta), minkä maan lakia toiminnassa on noudatettava (sovellettavan lain valinta) ja miten yhdessä Pohjoismaassa tehty ratkaisu on lainvoimainen ja toimeenpantavissa muissa Pohjoismaissa (tunnustaminen ja täytäntöönpano). Tällainen selvennys on tärkeä, kun laissa on eroavaisuuksia maiden välillä. Viranomaisyhteistyötä ja toimivallan jakoa Pohjoismaiden välillä koskevissa asioissa on usein päädytty yleissopimuksen solmimiseen.

\section{Lainsäädännön periaatteiden} yhdenmukaistaminen

Tietyn alan lainsäädännön periaatteiden yhdenmukaistaminen ei välttämättä tarkoita yksittäisten lain määräysten yksityiskohtaista yhdenmukaistamista. Periaatteiden yhdenmukaistaminen voi olla ajankohtaista esimerkiksi silloin, kun huomattavat organisatoriset erot vaikuttavan lain rakenteeseen. Periaatetason yhdenmukaistaminen mahdollistaa kansallisen joustavuuden mutta aiheuttaa samalla riskin, että kansallisten sääntöjen erilaiset yksityiskohdat luovat uusia rajaesteitä.

On syytä kiinnittää erityistä huomiota siihen, ettei niin pääse käymään.

\section{Tukea kansallisiin lainsäädäntöpoliittisiin pohdintoihin}

Pohjoismaisen oikeusyhteistyön tavoitteena voi olla jonkin ajankohtaisen lainsäädäntöasian perusteellinen pohdinta. Mailla ei välttämättä ole kaikilla aloilla riittävästi toivottua asiantuntemusta lainsäädännön tarkoituksenmukaisuuden arvioimiseksi. Joskus kaikilla Pohjoismailla ei ole käytössään samoja lainsäädäntötyössä tarvittavia tietoja, koska ne esimerkiksi osallistuvat eri tavoin kansainväliseen yhteistyöhön. Monesti poh- joismainen oikeusyhteistyö tarjoaa laajemman kokemuspohjan lainsäädäntökysymysten arviointiin. Perinpohjaisten pohdintojen tuloksena on mahdollista saada entistä yhtenäisempiä ratkaisuja, tai vaihtoehtoisesti maiden erilaisia ratkaisuja voidaan "testata" ja perustella selvemmin maiden erilaisilla olosuhteilla tai arvovalinnoilla.

\section{Tiedon ja kokemusten vaihto}

Pohjoismainen oikeusyhteistyö voi myös olla rajallisempaa ja keskittyä lainsäädännön kannalta tärkeään tiedon ja kokemusten vaihtoon. Sitä voidaan täydentää yhteispohjoismaisilla tiedon etsintään ja systematisointiin tähtäävillä toimilla mikä käytännössä useimmiten tapahtuu pohjoismaisten seminaarien muodossa. Tällainen tiedon ja kokemusten vaihto voi edistää yhtenäisempää lainsäädäntöä tai ainakin parantaa maiden lainsäädännön laatua. Käytännössä vaikutus on kuitenkin rajallisempi, koska tiedonvaihto ei johda yhteisten selvitysten, muotoilujen tai pohdintojen tekemiseen uutta lainsäädäntöä valmisteltaessa.

\section{Pohjoismainen työpaja ja arviointi lainsäädäntötyössä}

Useita - etenkin uusia - asioita voidaan ratkaista eri tavoin lainsäädännössä. Pohjoismaat saattavat eri syistä valita tietyn ratkaisun ajankohtaiseen yhteiskunnalliseen ongelmaan. Joskus muut Pohjoismaat kokevat, ettei aika ole vielä kypsä kyseiselle ratkaisulle. Jokin Pohjoismaa voi silloin toimia uuden mahdollisen lainsäädäntöratkaisun työpajana. Edelläkävijämaa voi siinä tapauksessa esitellä mahdollista ratkaisua muille maille, jotka saattavat kiinnostua ratkaisusta saatujen kokemusten arvioinnista. 


\section{Oikeusyhteistyö rajaesteiden torjumisessa}

\section{Mitä rajaesteet ovat?}

Pohjoismaiden passivapaus ja yhteiset työmarkkinat ovat perustavia seikkoja Pohjoismaiden välisen liikkuvuuden edistämisessä ilman maarajoista aiheutuvia esteitä. Liikkuvuutta saattavat kuitenkin estää muut säännöt, joiden perusteella maan asukkaita ja muita pohjoismaalaisia kohdellaan eri tavoin.

Tietyissä säännöissä tehdään ero kansalaisuuden tai pitkän asumisajan välillä. Muita esimerkkejä ovat yhdessä maassa saavutetut ja toisessa Pohjoismaassa pätemättömät oikeudet, ja se, että maiden asukkaiden on helpompi täyttää tiettyjä etuja koskevat kriteerit kuin naapurimaista tulevien henkilöiden tai että rajojen ylitys tuo mukanaan uusia velvoitteita.

Tällaisia olosuhteita kutsutaan usein "rajaesteiksi". Vaikkeivät ne ole rajat ylittävän liikkuvuuden kannalta ehdottomia esteitä, ne voivat joissakin tapauksissa aiheuttaa sen, että henkilö päättää olla muuttamatta tai matkustamatta toiseen Pohjoismaahan tai yritys päättää olla harjoittamatta toimintaansa toisessa Pohjoismaassa. Tämä ei välttämättä edistä yksilön eikä Pohjoismaiden resurssien optimaalista käyttöä.

Rajaeste voi olla seurausta tietyn alan tietoisesta poliittisesta päätöksestä. Jos päätös on tehty rajaestevaikutuksesta tietoisena, kyse ei enää ole ei-toivotusta tai tahattomasta rajaesteestä.

Yksittäisen maan kannalta tällaisilla säännöillä voi olla vahvat perustelut, kuten esimerkiksi tiettyjä virkoja koskeva kansalaisuusvaatimus. Jossakin maassa yrityksillä voi myös olla naapurimaata tiukempia velvoitteita tai vaatimuksia, koska niiden vaalimia arvoja priorisoidaan maassa enemmän. Syynä voivat myös olla maan erityisolot. Tällaisissa tilanteissa voidaan väittää, ettei kyse ole varsinaisesta rajaesteestä, koska säännöt vaikuttavat maan asukkaisiin samoin kuin muihin pohjoismaalaisiin, mutta siitä huolimatta erot voivat aiheuttaa ongelmia rajat ylittävälle elinkeinonharjoittamiselle.

\section{Rajaesteiden torjuminen}

Rajaesteen havaitsee helpoimmin siihen itse törmäävä henkilö. Pohjoismaiden ministerineuvostolla on neuvontapalvelujärjestelmä rajaesteiden torjumiseksi ja ehkäisemiseksi. Esteet tunnistetaan Pohjoismaiden ministerineuvoston Haloo Pohjola -tietopalvelun sekä alueellisten tiedotustoimistojen verkoston kautta. Ministerineuvosto on myös nimennyt oman Rajaesteneuvoston pääministereiden vuonna 2013 antaman yhteisen julkilausuman pohjalta. Rajaesteneuvosto arvioi tunnistettuja rajaesteitä, priorisoi niistä tärkeimpiä ja pyrkii löytämään niihin ratkaisun asiaa koskevissa maissa.

Rajaesteet voivat johtua sääntöjen soveltamisesta tai itse säännöistä. Käytännössä rajaesteitä muodostuu usein asetuksen määräysten myötä, mutta syy voi olla myös laissa.

Rajaestetyö koskee sekä esteiden poistamista että uusien esteiden ehkäisemistä.

Rajaesteen poistaminen voi edellyttää voimassa olevan määräyksen toisenlaista soveltamista tai määräyksen muuttamista. Tavallisesti maan hallitusta kehotetaan toimiin asiassa. Jos alalla on useita erilaisia rajaesteitä ja esteet ovat syntyneet eri maissa, parempia tuloksia tuottaisi sääntöjen kattavampaan tarkasteluun tähtäävä pohjoismainen yhteistyö, jonka tavoitteena olisi poistaa rajaesteitä. Kun useita esteitä tarkastellaan samalla kertaa, on helpompi arvioida yksittäisen maan tarvetta säilyttää tietty sääntö ja rajaesteen poistamisesta saatavaa hyötyä.

Uusia rajaesteitä voidaan ehkäistä ja välttää sekä uutta säännöstöä koskevalla pohjoismaisella yhteistyöllä että maiden omalla valvonnalla. Kun maa hyväksyy uusia lakeja tai asetuksia, jotka voivat vaikuttaa liikkuvuuteen Pohjoismaissa, sen on arvioitava mahdollisia vaikutuksia ja painotettava rajaesteiden välttämistä sääntöjä laadittaessa ja hyväksyttäessä.

Uusien sääntöjen parissa tehtävällä pohjoismaisella oikeusyhteistyöllä voidaan varmistaa, 
ettei uusia rajaesteitä synny. Tällaisessa oikeusyhteistyössä pyritään välttämään sääntöjä, jotka vaikuttavat rajaesteiltä. Yhtenäisellä lainsäädännöllä torjutaan erisisältöisten, eri tavoin muotoiltujen ja tahattomasti rajaesteitä aiheuttavien sääntöjen hyväksymistä.

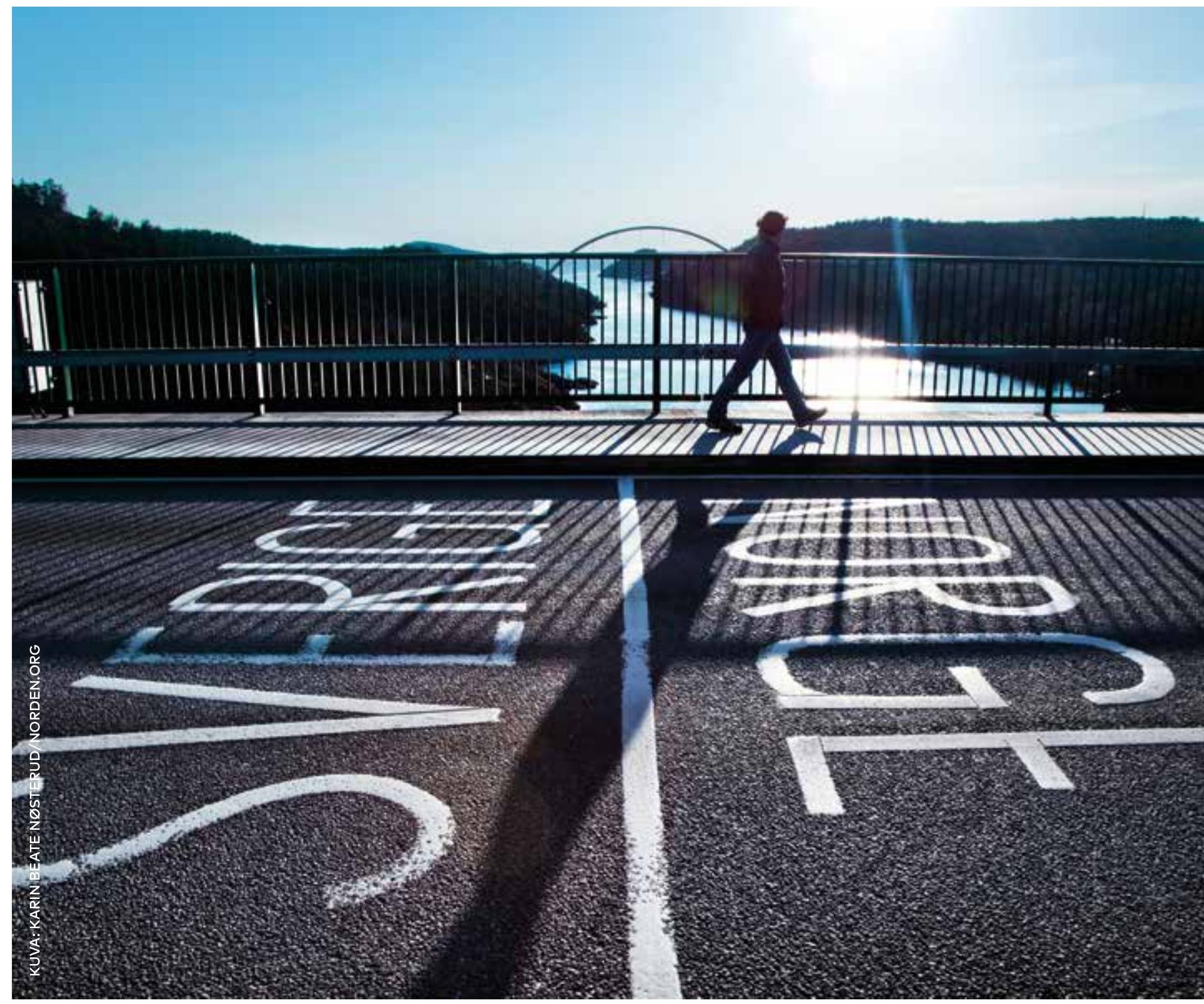




\section{Pohjoismainen oikeusyhteistyö kansallisen lainsäädännön aloilla}

\section{Yhteispohjoismaisen lainsäädännön tilanne}

Pohjoismaisen lainsäädännön kautta on saatu rakenteeltaan ja sisällöltään yhtenäisiä lakeja useilla eri aloilla. Muilla aloilla maat ovat hyödyntäneet toistensa kokemuksia ja osaamista uuden lainsäädännön valmistelussa joko kahdenvälisinä keskusteluina tai selvityksinä, joihin kaikki maat ovat osallistuneet. Hyvin tavallista on, että maa pyytää usein muilta Pohjoismailta tällaisia tietoja kansallisen lainsäädännön valmistelua varten. Näissäkin tapauksissa muiden Pohjoismaiden lainsäädäntö voi vaikuttaa maan lainsäädäntöön ilman, että yksittäisiä sääntöjä tai lakien rakennetta on yhtenäistetty.

Yhteispohjoismainen lainsäädäntötyö - jossa perusselvitykset tehtiin yhdessä ja jonka tavoitteina olivat samanlainen lain rakenne sekä mahdollisimman pienet erot sääntöjen sisällössä - on käytännössä keskeytynyt 1980-luvun yhteispohjoismaisen kauppalakihankkeen jälkeen. Kysymys kuuluukin: johtuuko tämä siitä, että yhteispohjoismainen lainvalmistelu vie liian paljon aikaa eikä anna riittävästi tilaa kansalliselle osallistumiselle eri tavoin eikä näkökulmien kansalliselle arvioinnille, vai siitä, että yli 100 vuotta jatkunut pohjoismainen lainsäädäntöyhteistyö on jo niin kattavaa - erityisesti yksityisoikeuden alalla - kuin ylipäätään on realistista odottaa. Siinä mielessä yhteispohjoismaista lainsäädäntöä koskevan pohjoismaisen oikeusyhteistyön voidaan jo sanoa saavuttaneen tavoitteensa.

Lisääntyvä liikkuvuus ja taloudellinen kanssakäyminen muodostavat entistäkin vahvemman pohjan jo olemassa olevalle yhteispohjoismaiselle lainsäädännölle. Useat seikat puoltavat sen säilyttämistä.

\section{Yhteispohjoismaisen lainsäädännön ylläpito \\ Yksittäinen maa saattaa muuttaa lakiaan myös niiltä osin, kuin se on laadittu yhteispohjoismai- sena lainsäädäntönä. Vain poikkeustapauksissa yhteispohjoismainen lainsäädäntö pohjautuu pohjoismaiseen yleissopimukseen, joka velvoittaa}

maata pitäytymään tietyssä säännössä. Helsingin sopimus (artikla 41) edellyttää kuitenkin, että jos maa haluaa tehdä tällaisen muutoksen, sen on tiedotettava asiasta muille maille. Ainoastaan kiireisissä tapauksissa, tai jos kyseessä on vähemmän merkittävä määräys, tiedottamista ei vaadita.

Tiedotusvelvollisuutta ei kuitenkaan aina noudateta, mikä lisää yhtenäisen säännöstön eriytymisen vaaraa ja voi aiheuttaa uusia rajaesteitä. Tiedottamisen ansiosta muut maat voivat tehdä aloitteen yhteispohjoismaisten neuvottelujen käynnistämisestä tai antaa ideoita muutosta suunnittelevalle maalle. Jotta tämä olisi oikeasti mahdollista, asioista on tiedotettava varhaisessa vaiheessa, esimerkiksi silloin, kun asetetaan valmistelvelin ja annetaan sille tehtäväksi ehdottaa muutoksia lakiin pohjoismaisen yhteistyön pohjalta, tai viimeistään, kun lakimuutosehdotus lähetetään lausuntokierrokselle. Tiedotusvelvollisuuden tulee sisältyä lainvalmistelun kansallisiin sääntöihin ja suuntaviivoihin.

\section{Lakien yhteispohjoismaiset tarkistukset?}

Pohjoismaisen yhteistyön puitteissa laaditut lait voivat olla tarkistuksen tarpeessa myös yhteiskunnan ja oikeuden yleisen kehityksen seurauksena. Tällainen tarkistus tulee tehdä pohjoismaisena yhteistyönä eikä yksittäisen maan toimesta.

Näin toimittiin esimerkiksi kauppalakien kanssa. Merenkulun lainsäädäntöä tarkistettiin yhteispohjoismaisesti puolestaan uusien kansainvälisten yleissopimusten toteuttamiseksi. Muita lakeja ei ole tarkistettu pohjoismaisin voimin. Vuosina 1915-20 hyväksyttyä sopimuslakia ei ole muutettu oikeastaan lainkaan, vaikka sopimusten solmimistapoihin on tullut merkittäviä muutoksia. Asiantuntijoilla on eriäviä mielipiteitä siitä, onko tämä riittävä syy sopimuslain tarkistamiseen, mutta tarkistaminen tulee joka tapauksessa toteuttaa pohjoismaisena yhteistyönä. Immateriaalioikeuksia (teollis- ja tekijänoikeuksia) koskevan lainsäädännön perustana on kansainvälisiin yleis- 
sopimuksiin pohjautuva pohjoismainen oikeusyhteistyö. Näiden sääntöjen merkitys taloudellisen kehityksen kannalta on kasvanut huomattavasti, mutta viime vuosina niitä on muutettu Pohjoismaissa ilman yhteispohjoismaista lainvalmistelua.

Perheoikeuden, etenkin avioliittolain, parissa on tehty paljon pohjoismaista oikeusyhteistyötä. Samalla on havaittavissa, että jossakin maassa on saattanut olla suuria muutostarpeita. Esimerkiksi Ruotsissa oli 1970-luvulla tavoitteena yhteiselämän eri muotoihin neutraalimmin suhtautuva laki, joka helpottaisi avioerosääntöjä ilman pohjoismaisen oikeusyhteistyön tuomia mahdollisia rajoituksia. Perheoikeutta koskevat näkemykset vaikuttavat nyt olevan yhtenäisemmät Pohjoismaissa, mutta kansallisten lakiuudistusten seurauksena on muodostunut sääntöeroja. Pohjoismaiden ministerineuvosto rahoitti vuosina 1998-2002 laajan selvityksen Pohjoismaiden perhe- ja jäämistöoikeudesta ja siitä käy ilmi, miten toisilta oppimalla ja lainsäädäntöä sopeuttamalla voidaan saada aikaan yhtenäisempiä ja parempia sääntöjä kaikkiin Pohjoismaihin.

\section{Vanhentuneet yhteispohjoismaiset lait}

Joillakin aloilla yhteispohjoismaiset säännöt ovat menettäneet suuren osan käytännön merkityksestään yhteiskunnan kehityksen seurauksena. Tässä yhteydessä voikin olla ajankohtaista arvioida tarvetta pohjoismaiseen oikeusyhteistyöhön tilalle tulleiden uusien asioiden parissa. Vekseleitä ja sekkejä koskevat lait ovat esimerkkejä ensimmäisestä yhteispohjoismaisesta lainsäädännöstä. Vekselien ja sekkien tilalle on nyt tullut muita maksuvälineitä, jotka eivät kuitenkaan toistaiseksi ole olleet pohjoismaisen oikeusyhteistyön kohteena. Eurooppalaisiin sääntöihin perustuva yhteispohjoismainen säännöstö voisi helpottaa ja turvata Pohjoismaiden välisiä maksuja.

\section{Yhteispohjoismaista lainsäädäntöä uusilla aloilla?} Pohjoismaisen oikeusyhteistyön piiriin kuulumattomilla asioilla voi siis olla yhteys aloihin, joilla yh- teispohjoismaista lainsäädäntötyötä on jo tehty. Mitä tiiviimpi yhteys on kyseessä, sitä suurempi syy on harkita pohjoismaista oikeusyhteistyötä uudella alalla.

Vasta-argumenttina pohjoismaisen oikeusyhteistyön aloittamiseksi uusilla aloilla voi olla, että kyseessä on täysin kansallinen asia, sitä koskevien sääntöjen hyväksymisellä on kiire tai että poliittiselta taholta lainsäädäntöä halutaan vain yhdessä maassa. Tälä voi olla vaikutusta yhteistyön tavoitetasoon ja toimintatapaan. Jos yhteispohjoismainen lainsäädäntö ei aluksi tule kysymykseen, kansallisesta lainsäädännöstä voidaan saada muita maita hyödyttäviä kokemuksia ja arvioita. Maa voi silloin toimia "työpajana", joka testaa lainsäädäntöä muiden maiden puolesta ennen kuin ne päättävät omista toimistaan. Jos yhteispohjoismainen selvitys ei ole mahdollinen, ministeriötason kuulemiset voivat ehkäistä lainsäädännön tarpeettomia eroja ja estää uusien rajaesteiden syntymistä.

Yhteiskunnan uusissa haasteissa voi olla epäselvää, mistä ongelmat johtuvat ja mitä seurauksia niillä saattaa olla, jolloin pohjoismainen panostus voi antaa paremman pohjan ja laajempia näkökulmia kansallisten lainsäätäjien tekemiin arviointeihin: esimerkiksi miten tulisi arvioida uusista liiketoimintamalleista johtuvia uudentyyppisiä työsopimuksia niiltä osin, kun ne koskevat työnantajan velvollisuuksia työntekijää kohtaan sekä yhteiskuntavastuuta. Toinen esimerkki on maiden rajat ylittävän järjestäytyneen rikollisuuden torjunta ja maahanmuuton sääntely eri tavoin harjoitettavan ulkomaalaispolitiikan valossa.

Euroopan unionin toimivalta näiden sääntöjen osalta ei saa olla pohjoismaisen oikeusyhteistyön esteenä. Niin kauan kun Euroopan unioni ei käytä tätä toimivaltaansa, Pohjoismaat voivat oikeusyhteistyön puitteissa laatia Pohjoismaille sopivia sääntöjä samalla, kun odotetaan yleisluontoisempia sääntöjä. Nämä maat voivat myös toimia mallina tai inspiraationa laajemmalle eurooppalaiselle ratkaisulle. 


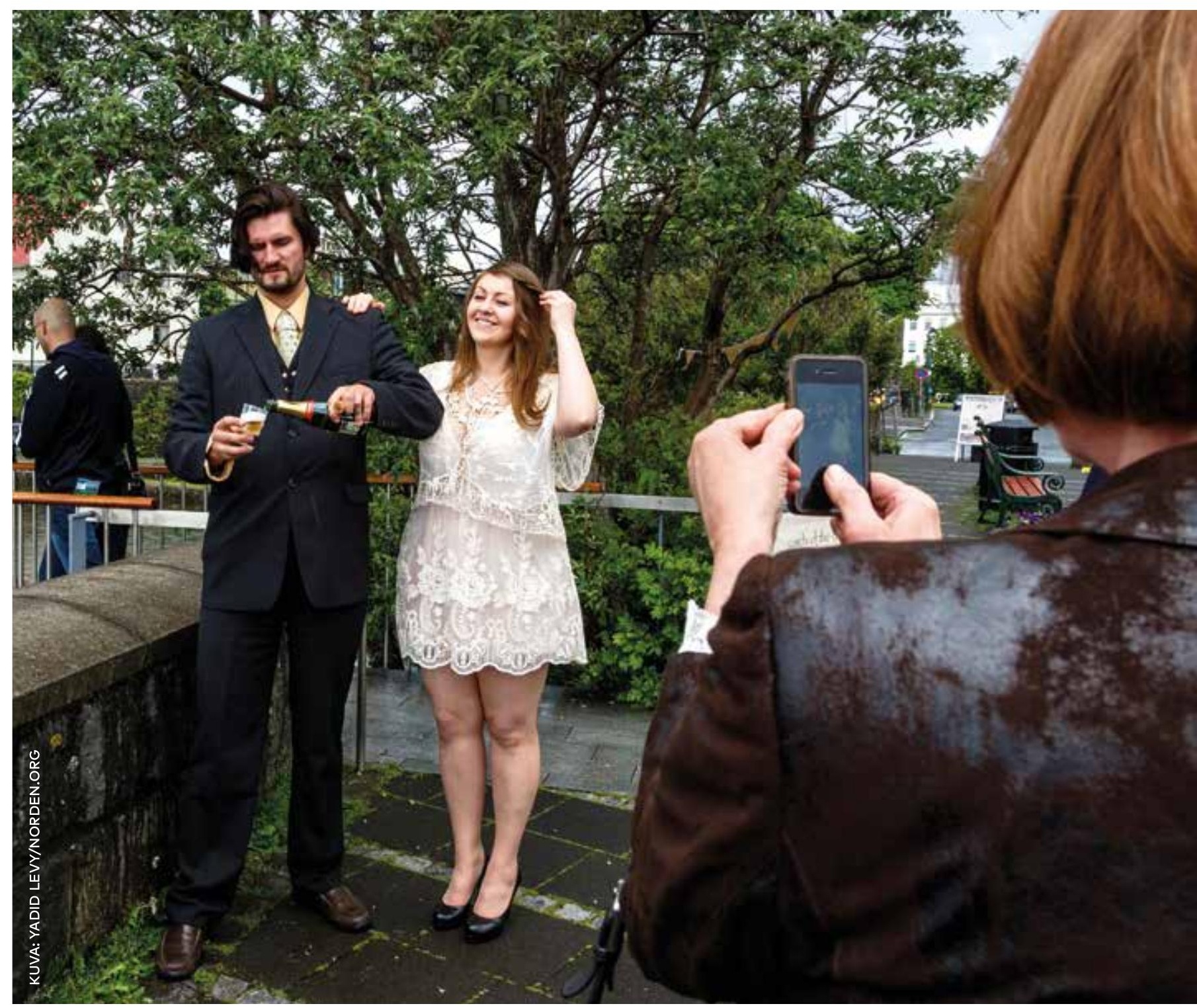

Pohjoismainen oikeusyhteistyö kansainvälisten yleissopimusten parissa

Siltä osin kun kansainvälinen yleissopimus ohjaa kansallista säännöstöä, sopimus muodostaa pohjan myös yhteispohjoismaiselle ratkaisulle. Pohjoismainen yhteistyö yleissopimuksen valmisteluvaiheessa voi edistää Pohjoismaiden kannalta parasta mahdollista ratkaisua. Euroopan unionin sopimuksentekovalta voi kuitenkin vaikut- taa valmistelun aikana tehtävän pohjoismaisen yhteistyön mahdollisuuksiin tai sen muotoon. Yleissopimuksen hyväksymisen jälkeen tehtävä pohjoismainen yhteistyö kansallisessa täytäntöönpanossa varmistaa sen, ettei sen aikana synny ei-toivottuja poikkeamia tai pahimmassa tapauksessa uusia rajaesteitä. Merenkulun lainsäädäntö on esimerkki laajasta pohjoismaisesta yhteistyöstä kummassakin suhteessa. 


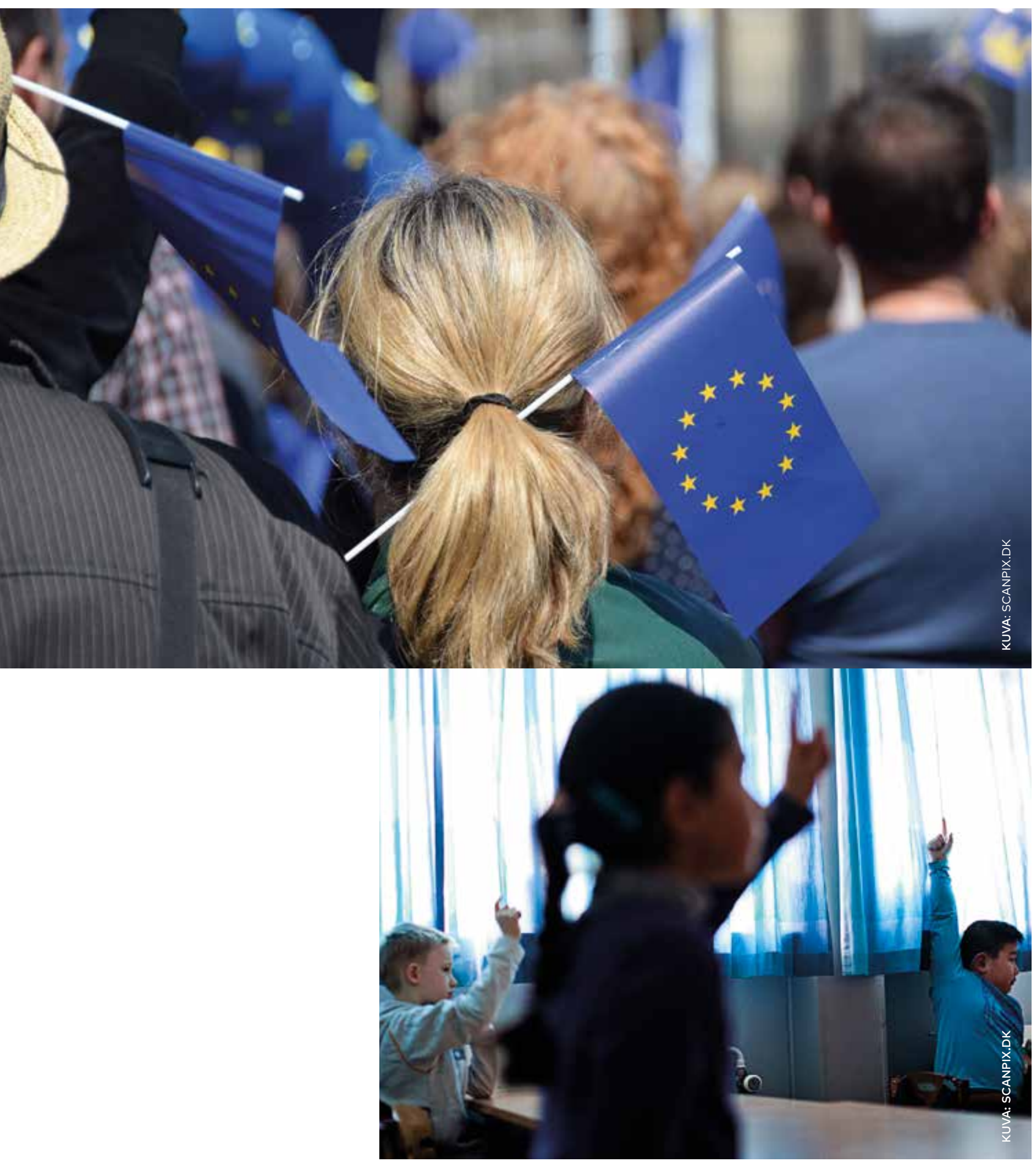




\section{EU-lainsäädännön piiriin kuuluvat alat}

\section{Oikeudelliset lähtökohdat EU- ja Eta-oikeudelle Pohjoismaissa}

Pohjoismaiden on noudatettava monilla aloilla Euroopan unionissa hyväksyttyä säännöstöä. Jäsenmaissa Ruotsissa, Suomessa ja Tanskassa tämä perustuu liittymissopimuksiin ja Islannissa ja Norjassa Eta-sopimuksiin. Koska sopimukset ovat jossain määrin erilaisia, maiden välillä on tiettyjä eroja siinä, miten pitkälti jäsenyys EU:ssa tai osallistuminen sen sisämarkkinoille estää maita säätämästä omia lakeja kyseisillä aloilla.

Lähtökohtana kaikissa maissa on, etteivät kansainväliset säännöt päde, jos niitä ei ole viety maan omaan lainsäädäntöön. EU-asetukset astuvat kuitenkin automaattisesti voimaan jäsenmaissa, ja Eta-maissa ne tulee saattaa sanatarkasti osaksi kansallista lainsäädäntöä. EU-direktiivit tulee sisällyttää yksittäisen jäsenmaan lainsäädäntöön usein täydentävien kansallisten määräysten kanssa, vaikka direktiivin määräyksillä olisi suora vaikutus jäsenvaltioon ja vaikka se siten menisi jäsenmaan omien lakien edelle.

EU- ja Eta-oikeus edistävät lainsäädännön yhtenäisyyttä Pohjoismaissa samassa määrin kuin Euroopassa. Kansallisen täytäntöönpanon erot voivat kuitenkin aiheuttaa oikeudellisia eroja ja mahdollisesti uusia rajaesteitä, kun EU- ja Eta-säännöt koskevat aiemmin yhteispohjoismaisen lainsäädännön piiriin kuuluneita asioita tai sellaisia asioita, joita ei ole aiemmin säännelty lähemmin Pohjoismaissa.

\section{Rajoittavatko EU ja Eta pohjoismaista oikeusyhteistyötä?}

Niin kauan kuin Euroopan unionilla on yksinomainen toimivalta solmia kansainvälisiä sopimuksia jäsenmaiden puolesta, pohjoismaiset EU-jäsenvaltiot eivät voi liittyä pohjoismaiseen yleissopimukseen. Tämä pätee myös, vaikkei Euroopan unioni ole allekirjoittanut yleissopimusta tai hyväksynyt sääntöjä asiasta.

Pohjoismaiden yhtenäiseen lainsäädäntöön tähtäävää pohjoismaista oikeusyhteistyötä voi- daan sen sijaan tehdä niin kauan kuin yksittäisissä maissa hyväksytyt säännökset eivät ole ristiriidassa senhetkisen EU-lainsäädännön kanssa. Tämä koskee sekä EU- ja Eta-oikeuden yleistä osaa että sekundäärioikeuden piiriin kuuluvia asetuksia ja direktiivejä. Mikäli samasta asiasta hyväksytään myöhemmin EU-sääntöjä, ne tulee panna täytäntöön Pohjoismaissa EU- ja Eta-oikeuden vaatimusten mukaisesti. Riittävän selkeän EU- ja Eta-oikeuden toimeenpanon varmistamiseksi Pohjoismaiden yhtenäisiä sääntöjä joudutaan tavallisesti kumoamaan tai muuttamaan niin, etteivät ne ole ristiriidassa EU- ja Eta-sääntöjen kanssa. Pohjoismaisen oikeusyhteistyön tarkoituksenmukaisuus yhtenäisten sääntöjen aikaansaamiseksi riippuu siitä, onko odotettavissa, että Euroopan unioni tekee aloitteen kyseistä asiaa koskeviksi säännöiksi.

Tällä on tietysti huomattava merkitys, kun arvioidaan pohjoismaisen oikeusyhteistyön käynnistämistä asioissa, joissa Euroopan unionilla on toimivalta tai jotka eivät kuulu sen toimivaltaan. Jos asia kuuluu Euroopan unionin toimivallan piiriin, mutta Eta-sopimuksen toiminta-alueen ulkopuolelle (esimerkiksi maanviljely, kalastus, luonnonsuojelu tai rikos- ja prosessioikeus), sen parissa voidaan tehdä rajallista oikeusyhteistyötä Länsi-Pohjolassa Islannin ja Norjan välillä - ja mahdollisesti myös Tanskan kanssa -, mikäli on kyse Tanskan "varaumaan" sisältyvästä rikos- ja prosessioikeudesta.

\section{Pohjoismaiden erityissäännöt ja tasavertainen kohtelu EU:ssa ja Etassa}

Pohjoismaisessa oikeusyhteistyössä, jota toteutetaan Euroopan unionin sekundäärioikeuden mukaisesti, tulee huomioida EU:n perussopimuksen ja Eta-sopimuksen perusperiaatteet silloin, kun on kyse näiden sopimusten piiriin kuuluvista asioista.

Pääsäännön mukaan pohjoismaiset erityissäännöt eivät voi rajoittaa EU:n ja Etan neljää vapautta, jotka koskevat ihmisten, tavaroiden, palveluiden ja pääoman vapaata liikkuvuutta. 
Tiettyjä ei-taloudellisia tavoitteita suojaavia esteitä voidaan kuitenkin hyväksyä, mikäli ne eivät loukkaa vapauksia kohtuuttomasti. Jos tällainen erityissääntö koskee kansalaisuutta, sillä voidaan suojata vain perustamissopimuksessa erikseen mainittua seikkaa. Mikäli neljään eri vapauteen vaikuttava pohjoismainen erityissääntö pohjautuu muihin kuin kansallisuutta koskeviin kriteereihin, sen avulla voidaan vaalia muita seikkoja sopimusten oikeuskäytäntöä mukaillen.

Sopimukset sisältävät lisäksi kansallisuuteen perustuvan syrjivän kohtelun yleisiä kieltoja (Euroopan unionin toiminnasta tehdyn sopimuksen (SEUT) artikla 18 ja Eta-sopimuksen artikla 4). Pohjoismaat eivät voi asettaa muiden EU- tai Eta-maiden kansalaisia toiseen, omia kansalaisiaan heikompaan oikeudelliseen asemaan. Tämän seurauksena yksi tai useampi Pohjoismaa ei voi myöskään antaa yhtenäisen lainsäädännön perusteella Pohjoismaiden kansalaisille muita EU- tai Eta-maiden kansalaisia parempaa oikeudellista asemaa. Se voi myös, mutta ei välttämättä, olla ristiriidassa kansalaisuuteen perustuvaa syrjintää koskevan kiellon kanssa, koska kyseessä on asuinpaikkaan tai oleskeluun Pohjoismaissa pohjautuvat eri säännöt, kunhan nämä säännöt ovat samat kaikille Pohjoismaissa asuville tai oleskeleville EUja Eta-kansalaisille.

\section{Oma yhteispohjoismainen lainsäädäntö EU- ja Eta-sopimusten aloilla edellyttää erityistä arviointia}

Kun tulee ajankohtaiseksi käynnistää pohjoismaista oikeusyhteistyötä yhtenäisen pohjoismaisen lainsäädännön saamiseksi EU- ja Eta-sopimusten piiriin kuuluvalla alalla, on hyvä tarkastella lähemmin - ja konkreettisesti juuri kyseisellä alalla -, mitä toimintavapauksia EU- tai Eta-säännöstö antaa pohjoismaiselle lainsäädännölle. Tämä raportti ei sisällä ehdotonta arviota asiasta, vaan tässä otetaan esiin useita aloja, joilla pohjoismainen oikeusyhteistyö voi olla ajankohtaista alustavan arvion mukaan. Asiaa onkin syytä tarkastella lähemmin tältä pohjalta.

\section{Pohjoismainen oikeusyhteistyö EU- ja Eta-sääntöjen parissa}

Jos alalla on valmisteltu ja hyväksytty EU-lainsäädäntöä, se määrittää pohjoismaisen oikeusyhteistyön tavoitteen ja muodon. Työ on tällöin erilaista, koska kyse on EU- ja Eta-sääntöjen valmistelusta tai täytäntöönpanosta. Se, että uusia EU-sääntöjä laaditaan suurina paketteina kireässä aikataulussa, aiheuttaa erityishaasteita pohjoismaiselle oikeusyhteistyölle sekä valmistelun että täytäntöönpanon yhteydessä. Yksittäisissä tapauksissa voi olla epäselvää, tuleeko uudet säännöt laatia osaksi Eta-sopimusta, mikä aiheuttaa ongelmia yhteistyössä, johon myös Islanti ja Norja osallistuvat.

\section{EU- ja Eta-sääntöjen valmistelu}

Valmistelussa on eri vaiheita. Alkuvaiheessa - ennen kuin Euroopan komissio on esitellyt asiaa koskevan analyysin tai ehdotuksen vihreän tai valkoisen kirjan muodossa - Pohjoismaat voivat yhteistyössä ehdottaa alalle uutta lainsäädäntömallia, joka perustuu pohjoismaisiin arvoihin ja pohjoismaiseen malliin. Tämä voi edellyttää Pohjoismailta yhteistä peruskäsitystä alaan liittyvistä arvoista ja mielenkiinnon kohteista. Sen ei kuitenkaan välttämättä edellytä yksimielisyyttä ehdotuksen yksityiskohdista, sillä pohjoismaista mallia voidaan usein toteuttaa eri tavoin. Pohjoismaisen aloitteen tavoitteena voi myös olla nykyisen sekundäärioikeuden tarkistaminen. Yhteisistä ideoista ja näkökulmista voidaan muotoilla ehdotuksia Euroopan komissiolle, Euroopan parlamentille tai muille jäsenvaltioille. Niitä voidaan tehdä myös uusia säädöksiä valmistelevissa teknisissä komiteoissa, joihin sekä jäsenvaltioilla että Efta- tai Eta-mailla on mahdollisuus osallistua.

Uusien EU-säädösten valmistelussa pohjoismaista oikeusyhteistyötä tehdään hallitusyhteistyönä, jonka merkitys riippuu siitä, miten muut pohjoismaiset sidosryhmät päättävät esiintyä vaikuttaakseen Euroopan unionin toimijoihin.

Kun komissio on laatinut analyysin tai ehdotuksen (vihreän tai valkoisen kirjan), yhteistyötä tehdään esimerkiksi koordinoimalla lausuntovastauksia, antamalla yhteisiä lausuntovastauksia tai 
pitämällä epävirallisesti yhteyttä Euroopan komission, Euroopan parlamentin ja muden jäsenvaltioiden kanssa. Efta- tai Eta-maat eivät saa osallistua asian jatkokäsittelyyn Euroopan unionin neuvostossa, mutta yhteydenpito Pohjoismaiden välillä on täysin mahdollista ennen asian käsittelyä Euroopan unionin neuvostossa tai Euroopan parlamentissa. Tässä vaiheessa on kuitenkin varauduttava siihen, että kansalliset tarpeet ja edut menevät pohjoismaisen yhteistyön edelle, mikäli ratkaisut eivät vaikuta optimaalisilta yksittäisen maan kannalta. Jos parlamentilla on kansallinen päätösprosessi pahasti kesken neuvottelujen aikaan, pohjoismaista yhteistyötä voi käytännössä olla vaikea käynnistää siinä vaiheessa.

Laaja pohjoismainen yhteistyö ei ole realistista kaiken uuden EU-lainsäädännön valmistelussa.

Tärkeimpiä esineuvottelut voivat olla silloin, kun Euroopan komissio valmistelee asetusta tai direktiiviä tavoitteena tietyn alan sääntöjen täysi yhdenmukaistaminen. Joillakin aloilla Pohjoismaiden intressit voivat erota toisistaan niin, että ne kokevat hyödyllisemmäksi etsiä muita liittolaisia valmisteluvaiheessa. Islannille ja Norjalle voi olla tarpeen ajaa omia etujaan ennemmin Efta- tai Eta-kanavien kautta kuin yhdessä kolmen pohjoismaisen EU-jäsenvaltion kanssa.

Jos Pohjoismaat havaitsevat, että tiettyä alaa koskevalla uudella EU-lainsäädännöllä ei ole todellista merkittävää vaikutusta niihin senhetkisessä tilanteessa, maat eivät välttämättä halua varata resursseja alaa koskevaan pohjoismaiseen oikeusyhteistyöhön valmisteluvaiheessa. Kaikille Pohjoismaille on kuitenkin eduksi varmistaa uusien EU-sääntöjen täsmällinen ja selkeä muotoilu, mikä helpottaa niiden kansallista täytäntöönpanoa ja mahdollistaa niiden sisällyttämisen pohjoismaiseen oikeuteen johdonmukaisen säännöstön säilyttämiseksi. Tämä näkökulma koskee erityisesti aloja, joilla on aiemmin ollut paljon yhteispohjoismaista lainsäädäntöä.

\section{EU- ja Eta-sääntöjen täytäntöönpano}

Uuden EU-lainsäädännön täytäntöönpano tapahtuu usein suuressa aikapaineessa. Aikapaine kas- vaa entisestään, kun uusi EU-lainsäädäntö sisältyy isoon "pakettiin" ja sen täytäntöönpanon aikataulu on tiukka.

Uusien asetusten täytäntöönpanon seurauksena saatetaan tarvita muutoksia olemassa olevaan kansalliseen lainsäädäntöön. Pohjoismaiselle oikeusyhteistyölle on eniten tarvetta, mikäli asetus edellyttää voimaan astuessaan täydentäviä kansallisia määräyksiä tai olemassa olevaa yhteispohjoismaista lainsäädäntöä joudutaan muuttamaan asetuksen takia. Direktiivin täytäntöönpanossa on pohdittava, miten sen tavoitteet ja sanamuoto voidaan parhaiten ilmaista kansallisessa lainsäädännössä ja vielä tavalla, joka muutenkin sopii kansalliseen lainsäädäntöön. Pohjoismaisesta yhteistyöstä voi olla suurta hyötyä, kun pyritään selvittämään mahdollisimman hyvin direktiivin antamaa toimintatilaa ja välttämään täytäntöönpanon hajanaisuutta ja sen aiheuttamia tahattomia uusia rajaesteitä.

Täytäntöönpanon aikapaineesta voi muodostua este pohjoismaiselle oikeusyhteistyölle. Toisaalta yhteistyö voi säästää aikaa, esimerkiksi jos jokin maa voi sen avulla hyödyntää muiden Pohjoismaiden resursseja. Tämä onnistuu helpoimmin alalla, jolla Pohjoismaiden lainsäädäntö on jo suhteellisen yhtenäistä. Direktiivien täytäntöönpanon yhteydessä herää usein kysymyksiä niiden tulkinnasta, jota voidaan selvittää paremmin pohjoismaisen oikeusyhteistyön avulla. Sen kautta myös Islanti ja Norja voivat saada paremmin tietoa Euroopan unionin poliittisen tason valmistelusta, johon niillä ei ole lupaa osallistua.

EU-direktiivit voivat erota tähänastisen tai tulevan kansallisen lainsäädännön tyypillisestä rakenteesta ja muotoilusta. Täytäntöönpanon aikapaine voi estää, että kansallisiin täytäntöönpanosääntöihin saadaan samanlainen rakenne kuin oikeuspedagogisesti olisi tärkeää. Yksi mahdollisuus on pyrkiä myöhemmin pohjoismaisen yhteistyön puitteissa mahdollisesti täytäntöönpanon arvioinnin yhteydessä - laatimaan ja muotoilemaan sääntöjä, jotka täyttävät selkeää lakikieltä ja saavutettavuutta koskevat pohjoismaiset tavoitteet. 


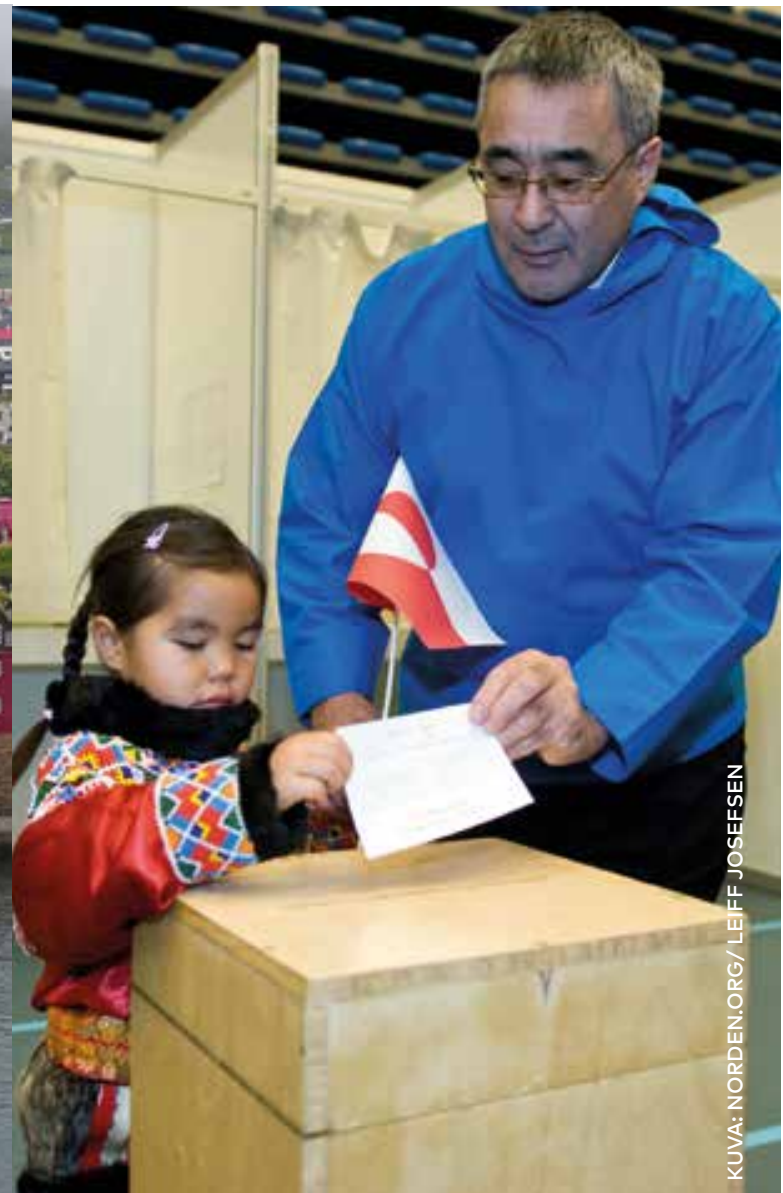
inito

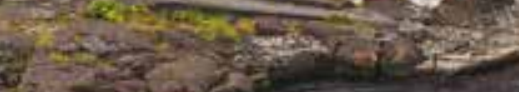
entecting
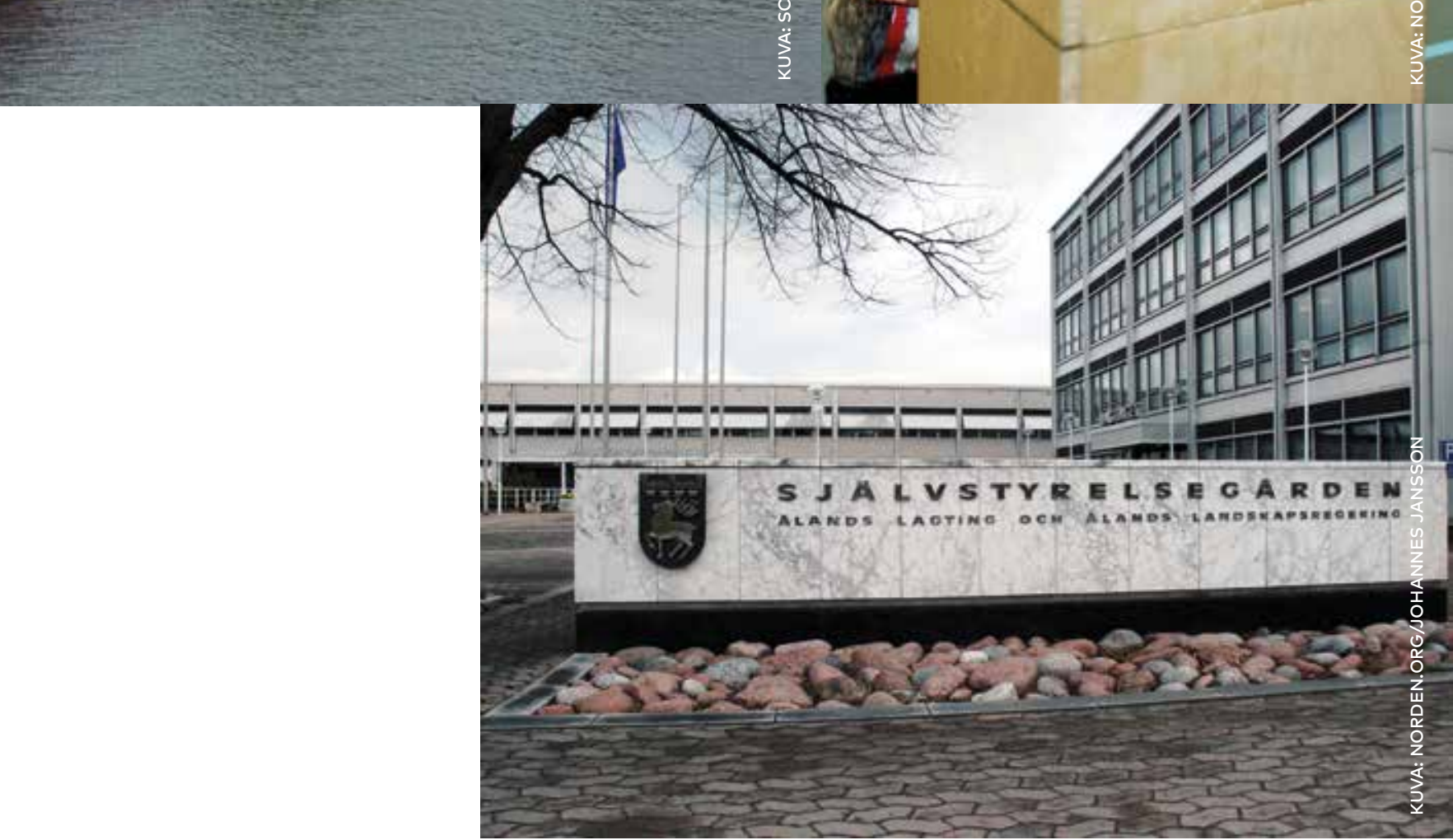


\section{Pohjoismainen oikeusyhteistyö Ahvenanmaan, Färsaarten ja Grönlannin kannalta}

Pohjoismaista oikeusyhteistyötä on tehty lähtökohtaisesti viiden Pohjoismaan - Islannin, Norjan, Ruotsin, Suomen ja Tanskan - välillä. Ahvenanmaa, Färsaaret ja Grönlanti ovat vähitellen saaneet laajan itsehallinnon, vaikka sen laajuudessa onkin eroja. Osallistuminen pohjoismaiseen yhteistyöhön on kiinnostanut myös itsehallintoalveilla, ja ne ovat olleet siinä mukana tietyssä määrin.

Ahvenanmaa, Färsaaret ja Grönlanti kuuluvat Pohjoismaiden neuvostoon (Helsingin sopimus artiklat 44 ja 47). Ne osallistuvat myös Pohjoismaiden ministerineuvoston työhön ja voivat yhtyä ministerineuvoston tekemiin päätöksiin (Helsingin sopimuksen artiklat 60 ja 63). Ahvenanmaan, Färsaarten ja Grönlannin edustajia on tapana kutsua ministerikokouksiin ja virkamieskomiteoiden kokouksiin.

Pohjoismainen oikeusyhteistyö merkitsee eri asioita Ahvenanmaalle, Färsaarille ja Grönlannille. Niin kauan kun niillä on itsenäinen lainsäädäntövalta, yhteispohjoismaiset ratkaisut ovat yhtä ajankohtaisia niille kuin viidelle Pohjoismaalle. Lainsäädännön seurauksena syntyvistä rajaesteistä on niille vähintään yhtä paljon haittaa kuin viidelle Pohjoismaalle. Koska Ahvenanmaalla, Färsaarilla ja Grönlannilla itsellään on rajalliset resurssit lainvalmisteluun paneutumiseen, pohjoismaisesta selvitystyöstä voi olla erityistä hyötyä niille. Toisaalta rajallisten resurssien takia ne joutuvat priorisoimaan tarkasti aktiivista osallistumistaan yhteistyöhön. Sen takia viidellä Pohjoismaalla tulee olla erityisvastuu siitä, ettei Pohjoismaiden lainsäädäntö aiheuta rajaesteitä Ahvenanmaalle, Färsaarille ja Grönlannille.

Viiteen Pohjoismaahan verrattuna Ahvenanmaalla, Färsaarilla ja Grönlannilla on erityisasema Euroopan unionissa. Färsaaret ja Grönlanti ovat jättäytyneet täysin EU:n ja Etan ulkopuolelle. Euroopan unionin säännöstö voi kuitenkin vaikuttaa niiden lainsäädäntöön usealla eri tavalla.
Ne hyväksyvät tai ottavat käyttöön lakeja kokonaan tai osittain EU-sääntöihin (esimerkiksi osakeyhtiölait) perustuvan Tanskan valtakunnan lainsäädännön mukaisesti. Niiden itsenäiseen säännöstöön voi vaikuttaa myös se, että niiden on noudatettava Euroopan unionin sisäisiä standardeja varmistaakseen pääsynsä Euroopan markkinoille.

EU- ja Eta-oikeuden yhdenvertaisen kohtelun periaate ja kansalaisuuteen perustuvan syrjinnän kielto nostavat esiin erityiskysymyksiä färsaarelaisten ja grönlantilaisten asemasta muissa Pohjoismaissa. Nämä periaatteet voivat toimia myönteisesti tai kielteisesti - niistä on joko etua Färsaarten ja Grönlannin asukkaille tai ne estävät heitä saamasta saman oikeudellisen aseman muiden Pohjoismaiden kansalaisten kanssa.

Tanskan kansalaisina Färsaarten ja Grönlannin asukkaat voivat lähtökohtaisesti vaatia EU- tai Eta-oikeuden myöntämiä EU- tai Eta-maiden asukkaita koskevia oikeuksia, vaikka kolmannen maan kansalaiset eivät voi sitä tehdä.

Yhteispohjoismaisessa lainsäädännössä, jonka perusteella yhdessä Pohjoismaassa annetut luvat ja oikeudet tunnustetaan muissa Pohjoismaissa, onkin pohdittava, voiko se koskea myös Färsaarten ja Grönlannin lainsäädäntöön perustuvia lupia ja oikeuksia. Tämä voi herättää kysymyksiä niin viidessä Pohjoismaassa kuin Färsaarilla ja Grönlannissa. Viidessä Pohjoismaassa täytyy mahdollisesti pohtia, velvoittavatko EU- tai Eta-oikeuden vaatimukset tasavertaisesta kohtelusta niitä tunnustamaan muiden EU- tai Eta-maiden vastaavat luvat ja oikeudet, kun ne kerran tunnustavat Färsaarten ja Grönlannin lainsäädännön mukaiset luvat ja oikeudet. 


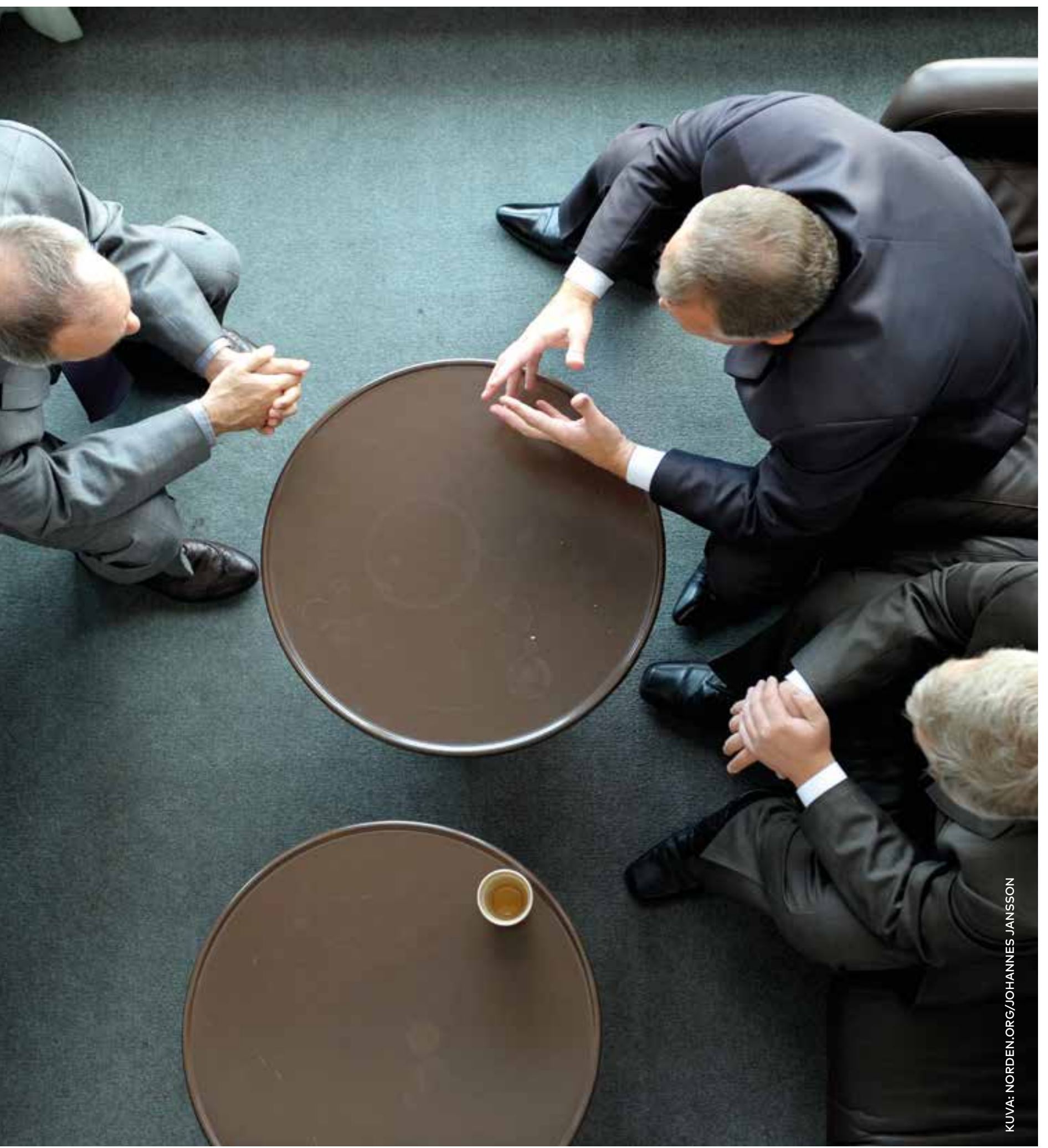




\section{Pohjoismainen oikeusyhteistyö - tiivistelmä vuoden 2018 tilanteesta}

\section{Merkittävää yhteispohjoismaista lainsäädäntöä 100 vuoden ajan}

Yli 100 vuoden ajan oikeuden eri aloilla on hyväksytty useita yhteispohjoismaisia lakeja etenkin yksityisoikeudellisissa kysymyksissä, joita voi esiintyä maiden asukkaiden välillä tai niiden harjoittamassa toiminnassa. Niistä useimmat pohjautuvat yhteispohjoismaiseen valmisteluun tai ovat tulosta valmisteluvaiheen tiiviistä yhteistyöstä maiden välillä. Työ on perustunut pragmaattisiin neuvotteluihin ja pohdintoihin, ja kaikki maat ovat säilyttäneet täyden oikeudellisen riippumattomuutensa lainsäätäjinä. Ainoastaan harvoissa asioissa yhteispohjoismainen lainsäädäntö perustuu maita kansainvälisoikeudellisesti velvoittavaan pohjoismaiseen yleissopimukseen. Tällaiset yleissopimukset koskevat usein tuomioistuinten toimivaltaa sekä oikeuden päätösten tunnustamista ja täytäntöönpanoa.

Viimeisten 20-30 vuoden aikana yksityisoikeuden yhteispohjoismaista lainsäädäntöä ei ole enää seurattu samaan tapaan. Onkin syytä pohtia, onko yhteispohjoismainen lainsäädäntö jo niin kattavaa, ettei lakien harmonisoinnin jatkamiselle ole enää realistista pohjaa. Se ei kuitenkaan mukaile Helsingin sopimuksen artiklaa 4: "sopimuspuolten on jatkettava lakiyhteistyötä mahdollisimman suuren yhdenmukaisuuden saavuttamiseksi yksityisoikeuden alalla". Helsingin sopimuksen rajallinen seuranta on ristiriidassa muun yleissopimuksiin perustuvan lakien harmonisoinnin kanssa, jota Pohjoismaat ovat noudattaneet tarkasti. Se ei myöskään mukaile pääministerien yhteistä tavoitetta siitä, että Pohjoismaiden tulee olla maailman integroitunein alue.

\section{Pohjoismaisen lainsäädännön myöhemmät muutokset ja ylläpito}

Useimpia yhteispohjoismaisia lakeja on muutettu myöhemmin ainakin yksittäisten määräysten osalta. Joissakin maissa niitä on saatettu myös korvata kokonaan uudella lailla. Muutoksia on tehty lähinnä poikkeustapauksissa ja pohjoismaisen yhteistyön puitteissa. Maat ovat usein jättäneet tiedottamatta muille Pohjoismaille suunnitelluista muutoksista, vaikka Helsingin sopimuksen artiklassa 41 niin on päätetty.

Kansalliset muutokset yhteispohjoismaiseen lainsäädäntöön ovat usein olleet merkki asioiden uudelleenarvioinnista ja säännösten päivityksestä yhteiskunnan ja sen arvojen muuttumisen seurauksena. Tällaiset muutokset ovat voineet tulla ajankohtaisiksi eri aikoihin ja tavoin eri Pohjoismaissa. Yksittäiset maat ovat näissä tapauksissa toimineet lainsäädännön työpajana, jossa on kehitetty ja toteutettu uusia ideoita, joista on myöhemmin voinut olla hyötyä muille maille. Tämä on luultavasti vielä ajankohtaisempaa aloilla, joilla ei ole ollut yhteispohjoismaista lainsäädäntöä, mutta joilla on kuitenkin havaittavissa kiinnostusta vastavuoroiseen kokemusten hyödyntämiseen.

\section{Oikeusyhteistyön nykyinen laajuus}

Vaikka yhteispohjoismaisella lainsäädännöllä on aiempaa vähemmän merkitystä yksityisoikeudessa, on tuskin perusteltua sanoa, että pohjoismaista yhteistyötä tehdään nyt vähemmän aloilla, joilla sen merkitys on ollut vähäisempi. Yksi esimerkki pohjoismaisesta oikeusyhteistyöstä on pohjoismainen ja eurooppalainen pidätysmääräys, joka sekä toimeenpanee EU-sääntöjä ja että syventää Pohjoismaiden välistä yhteistyötä rangaistavien toimien tutkinnassa.

\section{Pohjoismainen oikeusyhteistyö ja pohjoismaiset yleissopimukset \\ Pohjoismaisessa oikeusyhteistyössä on keski- tytty enimmäkseen suoraan Pohjoismaiden lainsäädäntöön ilman edeltäviä kansainvälis- oikeudellisesti sitovia yleissopimuksia. Tietyissä tapauksissa yleissopimuksia on kuitenkin käytet- ty: esimerkiksi päätettäessä toimivallan jakautu- misesta Pohjoismaiden välillä (lainkäyttövalta), varmistettaessa Pohjoismaassa tehdyn ratkai-}


sun tunnustaminen ja täytäntöönpano muissa Pohjoismaissa ja varmistettaessa, että Pohjoismaan säännöissä oman maan ja muiden maiden kansalaisia kohdellaan samalla tavalla ja että vaikutukset ovat muissa maissa samat kuin omassa maassa. Esimerkki viimeksi mainitusta on vuonna 1974 solmittu pohjoismainen ympäristönsuojelusopimus, jonka tavoitteena on varmistaa, että muiden Pohjoismaiden ympäristövaikutuksia käsitellään oman maan ympäristövaikutusten tapaan.

Euroopan unionin sopimuksentekovallan kehityksen seurauksena pohjoismaista yhteistyötä voidaan entistä harvemmin toteuttaa pohjoismaisten yleissopimusten muodossa. Pohjoismaista pidätysmääräystä koskeva yleissopimus vuodelta 2005 on kuitenkin esimerkki viime vuosina solmitusta pohjoismaisesta yleissopimuksesta.

\section{Oikeusyhteistyö EU- ja Eta-sääntöjen parissa}

Pohjoismaiden välillä ei tehdä järjestelmällistä yhteistyötä EU- ja Eta-sääntöjen valmistelussa ja yhtenäisessä täytäntöönpanossa. Sama koskee myös laaja-alaisia säädöksiä, kuten esimerkiksi palveludirektiiviä ja tietosuoja-asetusta, vaikka Pohjoismaat ovatkin olleet yhteydessä toisiinsa työn aikana. Pohjoismaiden ministeriöissä on todennäköisesti tehty paljon rinnakkaista työtä, jolta olisi vältytty tekemällä varhaisessa vaiheessa yhteinen selvitys sovitun työnjaon pohjalta. Erittäin tiiviistä yhteistyöstä on kuitenkin yksittäisiä esimerkkejä, kuten kuluttajasopimuksia koskeva direktiivi, joka pantiin täytäntöön sopimuslain muutosten myötä 1990-luvulla. Kansallinen täytäntöönpano on johtanut tiettyihin eroihin maiden lainsäädännössä, mutta siitä ei ole empiirisiä selvityksiä, joista kävisi yleisesti ilmi, missä määrin EU- tai Eta-säädösten täytäntöönpanon aikana rajallisesti tehty oikeusyhteistyö on aiheuttanut uusia rajaesteitä.

\section{Pohjoismaiden neuvoston asema oikeusyhteistyössä}

Pohjoismaiden neuvosto vaikuttaa tekevän entistä harvemmin konkreettisia oikeusyhteistyön aloitteita. Samalla on havaittavissa tiettyä tyytymättömyyttä aloitteiden seurantaan ministerineuvostossa, virkamieskomiteoissa ja kansallisella tasolla. Poliittisesta näkökulmasta saatetaan kokea, että asioiden käsittely virkamieskomiteoissa on aikaa vievää ja siinä keskitytään enemmän vastaperustelujen esittämiseen kuin uusiin ideoihin.

\section{Oikeusyhteistyö Pohjoismaiden ministerineuvostossa}

Pohjoismaiden ministerineuvostossa oikeusyhteistyö koostuu lähinnä käytännön toimijoiden tai asiantuntijoiden laatimista yksittäisiä asioita koskevista selvityksistä sekä pohjoismaisista seminaareista ja niistä laadittavista raporteista. Tällä tavalla saadaan usein tietoa täysin kansallisista lainsäädäntötoimista, mutta työn seurantana laaditaan harvoin pohjoismaista lainsäädäntöä. Toiminnan tavoite voi usein jäädä epäselväksi sekä se, onko sillä muuta tavoitetta kuin hyödyttää tietyn maan lainsäädäntöä. Tiettyjen raporttien osalta on epäselvää, seurataanko niitä - ja siinä tapauksessa miten - pohjoismaisissa yhteyksissä. Seminaareista ja selvityksistä saatavaa pohja-aineistoa pitää pystyä hyödyntämään paremmin pohjoismaisella tasolla. Pysyväksi käytännöksi tulee saada, että ministerineuvosto ottaa kantaa jatkoseurantaan. Tietyillä mailla tulee olla mahdollisuus jatkaa lainsäädännöllistä yhteistyötään, vaikkeivät kaikki maat osallistu siihen.

Maat tekevät joillakin aloilla jonkinasteista suoraa oikeusyhteistyötä Pohjoismaiden ministerineuvoston ulkopuolella. Esimerkkejä tästä ovat kuluttajansuoja ja tekijänoikeudet. Pohjoismaiden ministerineuvostossa on aiemmin ollut 
näitä asioita käsitelleitä ministerineuvostoja ja virkamieskomiteoita. Kun tietyn alan oikeusyhteistyö ei kuulu Pohjoismaiden ministerineuvostolle, sen käsittely riippuu entistä enemmän kansallisten ministeriöiden mielenkiinnon kohteista ja resursseista.

\section{Oikeusyhteistyö kansallisissa ministeriöissä}

Ministeriötason yleisen käsityksen mukaan pohjoismainen oikeusyhteistyö toimii hyvin tiedon ja kokemusten vastavuoroisessa vaihdossa ja siitä on hyötyä kansallisessa lainvalmistelussa. Samanaikaisesti ministeriöissä suhtaudutaan kriittisesti korkeampiin tavoitteisiin, ja ollaan sitä mieltä, ettei laajempaan oikeusyhteistyöhön, jonka tavoitteena olisi yhtenäinen lainsäädäntö sisällöllisesti tai rakenteellisesti, ole aikaa ja resursseja eikä siitä saataisi tarpeeksi konkreettista hyötyä.

\section{Lakimiesten pohjoismaiset asiantuntijayhteisöt} Lakimiesten pohjoismaiset asiantuntijayhteisöt ovat toimineet perinteisesti kansallisella ja pohjoismaisella tasolla. Viime vuosikymmenten aikana ne ovat eurooppalaistuneet ja kansainvälistyneet vahvasti, mikä näkyy selvästi myös yliopistoissa. Tämän takia pohjoismainen näkökulma on vaarassa jäädä taka-alalle, mutta monilla aktiivisilla pohjoismaisilla verkostoilla ja asiantuntijayhteisöillä voi olla merkitystä vahvemmassa pohjoismaisessa oikeusyhteistyössä.

\section{Pohjoismainen oikeusyhteistyö on usein henkilöistä} riippuvaa

Sekä ihmisten mielenkiinnon kohteet että yhteistyöhön suunnattavat resurssit vaikuttavat pohjoismaiseen oikeusyhteistyöhön. Tämän seurauksena yhteistyö on haavoittuvaista, kun asiasta innostuneet henkilöt jättäytyvät pois yhteistyöstä tai saavat uusia työtehtäviä. Pysyvämmästä rakenteesta voisi olla hyötyä yhteistyölle.

\section{Pohjoismainen oikeusyhteistyö on epävirallista}

Pohjoismaisen oikeusyhteistyön epävirallista luonnetta korostetaan usein sen vahvuutena. Sitä on helppo käynnistää - eikä siihen tarvita välttämättä virallisia päätöksiä. Yhteistyön seuranta on helppoa, sillä maiden viranomaiset voivat olla suoraan yhteydessä toisiinsa (Helsingin sopimuksen artikla 42). Myös tulokset ovat epävirallisia siinä mielessä, etteivät ne tule esille yleissopimuksissa tai muissa sitovissa kansainvälisoikeudellisissa sopimuksissa. Kun yhteistyön puitteissa laaditaan yhteispohjoismaista lainsäädäntöä, sen pohjana on yleensä epävirallinen vastavuoroinen ymmärrys asiaa koskevien lain säännösten sisällöstä ja muodosta.

Pohjoismaisen oikeusyhteistyön epävirallisuus on samalla myös sen heikkous. Työ jää muiden kansainvälisten velvoitteiden ja helposti myös maan muiden työtehtävien jalkoihin aika- ja resurssipaineessa. Entistä suurempi tietoisuus Helsingin sopimukseen liittyvistä velvoittavista odotuksista voi edistää oikeusyhteistyön vahvistamista.

Oikeusyhteistyö ei johda enää niin usein yhteispohjoismaiseen lainsäädäntöön. Sen takia se on menettänyt näkyvyyttään.

\section{Pohjoismainen näkökulma kansallisessa lainval- mistelussa}

Kansallisessa lainvalmistelussa on tapana ottaa huomioon ja hyödyntää muiden Pohjoismaiden tietoa ja kokemuksia useilla aloilla. Maiden välillä on kuitenkin eroja siinä, miten laajasti tätä toteutetaan ja onko se mahdollista lainvalmistelusta laadittujen suuntaviivojen mukaisesti. Sen vuoksi ei ole mitään varmuutta siitä, arvioidaanko kansallisen lainsäädännön valmistelun yhteydessä vaikutuksia muihin Pohjoismaihin tai pohjoismaalaisiin ja heidän maiden rajat ylittävään toimintaansa. 


\section{Pohjoismaisen oikeusyhteistyön vahvistaminen}

\section{Useita vahvistamismahdollisuuksia}

Pohjoismaista oikeusyhteistyötä voidaan vahvistaa monin eri tavoin. Siinä voidaan hyödyntää pohjoismaisen yhteistyön sekä nykyisiä että tulevia mahdollisuuksia. Joihinkin mahdollisuuksiin voidaan tarttua heti. Toisilla ehdotuksilla on merkitystä tietyn ajan päästä.

Mikään yksittäinen toimi ei kuitenkaan vaikuta olevan yksin ratkaisevassa asemassa pohjoismaisen oikeusyhteistyön vahvistamiseksi. On käynnistettävä useampia toimia ja lisättävä siten tietoisuutta pohjoismaisen oikeusyhteistyön tuomien mahdollisuuksien hyödyntämisestä.

Pohjoismaisen oikeusyhteistyön vahvistamista koskevat ehdotukset voidaan jakaa kahteen pääryhmään.

Ehdotusten ensimmäinen pääryhmä koskee yleisiä ehdotuksia kansallisen tai pohjoismaisen tason rutiinien muuttamisesta, organisatorisia toimia pohjoismaisella tasolla sekä Pohjoismaiden resurssien ja asiantuntijayhteisöjen parempaa hyödyntämistä. Niiden avulla pohjoismaisesta oikeusyhteistyöstä saadaan antoisampaa tulevaisuudessa ja voidaan varmistaa paremmin pohjoismaisen oikeusyhteistyön etujen vaaliminen.

Toisen pääryhmän ehdotuksissa käsitellään konkreettisia lainsäädäntöaloja ja -hankkeita. $\mathrm{Ne}$ voivat koskea uuteen lainsäädäntöön tähtääviä ehdotuksia tai ehdotuksia tietyn alan nykyisen lainsäödännön analysoinnista tai arvioinnista. Pohjoismaisen yhteistyön tavoitetasoa tulee arvioida eri yhteyksissä. Yhteistyön perusta voi vaihdella, kuten pohjoismaisesta oikeusyhteistyöstä saatavat tuloksetkin. Tällaisilla eroilla on merkitystä konkreettisen yhteistyön käynnistämistapojen priorisoinnissa.

Ehdotukset edistävät yhdessä tavoitetta tehdä Pohjoismaista maailman integroitunein alve pääministereiden syyskuussa 2016 antaman julkilausuman mukaisesti.

\section{Vahvistamisen tärkeitä edellytyksiä}

Pohjoismaisen oikeusyhteistyön todellinen vahvistaminen riippuu
- poliittisesta tahdosta priorisoida tiettyjä toimia

- kansallisen - ennen kaikkea ministeriöiden virkakoneiston ajasta ja resursseista toimeenpanon varmistamiseksi.

On syytä painottaa, että pohjoismaisen oikeusyhteistyön laajuus ja tehokkuus riippuu poliittisesta tahdosta Pohjoismaiden neuvostossa ja Pohjoismaiden ministerineuvostossa sekä maiden parlamenteissa ja hallituksissa. Tällaista poliittista priorisointia tarvitaan, jotta voidaan toteuttaa ajatus Pohjoismaista maailman integroituneimpana alveena, torjua Pohjoismaiden rajaesteitä ja tuoda pohjoismaista mallia paremmin esiin Euroopan tai globaalin tason neuvotteluiden pohjana tai inspiraationa.

Ministerineuvostoissa esiteltävät oikeusyhteistyötä koskevat poliittiset priorisoinnit riippuvat virkamieskomiteoissa tehtävästä valmistelusta. On tärkeää, ettei valmistelua rajoita se, että asiasta on saavutettava yksimielisyys virkamiestasolla. Alakohtaisten ministerineuvostojen vastuualueiden ulkopuolelle kuuluvassa oikeusyhteistyössä voidaan tehdä poliittisia priorisointeja esimerkiksi epävirallisissa ministerikokouksissa tai erityisissä ministerikonferensseissa, kuten Nordens tid er nu - Nyt Norden 2.0 -raportissa mainitaan.

Avainasemassa lainsäädännön valmistelussa on etenkin ministeriöiden virkakoneisto, mutta sen työpaine vaikuttaa olevan erittäin suuri saatavilla oleviin resursseihin verrattuna. Sen vuoksi ei ole realistista, että virkakoneisto tekee aloitteita tai osallistuu nykyistä laajempaan pohjoismaiseen lainsäädäntöyhteistyöhön, mikäli asiaa ei priorisoida poliittisesti. Pohjoismaisten asiantuntijayhteisöjen parempi hyödyntäminen voi helpottaa ministeriöiden työtä.

Pohjoismaisen oikeusyhteistyön esteeksi mahdollisesti muodostuvaa aikapainetta ja kansallisten asialistojen eroja tulee torjua

- laatimalla varhainen katsaus kansallista lainsäädäntöä ja tulevia kansainvälisiä velvoitteita koskevista suunnitelmista 
- päättämällä varhaisessa vaiheessa, mitä eurooppalaisia tai muita kansainvälisiä velvoitteita tulee panna täytäntöön pohjoismaisessa yhteistyössä ja tehdä sopiva työnjako

- hyödyntämällä osaavia pohjoismaisia asiantuntijayhteisöitä

- laatimalla pohjoismaisia arviointeja ja koosteita hyväksytystä lainsäädännöstä, josta voi olla hyötyä lakien myöhemmissä tarkistuksissa.

\section{Mitä hyötyä vahvemmasta pohjoismaisesta oikeusyhteistyöstä voi olla?}

Laajemmasta pohjoismaisesta lainsäädäntöyhteistyöstä voi olla monenlaista hyötyä. Yhteistyön aiheet, sisältö ja tavoitetaso voivat kuitenkin vaihdella.

Lakeja valmistellaan maissa yleensä aika- ja resurssipaineen alaisena, mikä voi vaikuttaa lain laatuun. Pohjoismainen oikeusyhteistyö voikin edistää maan lainsäädäntötyön laatua. Kyse voi olla esimerkiksi lainvalmistelun aikana tehtävästä yhteistyöstä, johon eri maat tuovat omaa osaamistaan ja resurssejaan sovitun työnjaon mukaisesti. Tällaisen vastavuoroisen tuen antaminen on helpompaa, mikäli eri maiden lainsäädännön rakenteet muistuttavat toisiaan kyseisellä alalla. Toisinaan yhteistyötä voidaan puolestaan tehdä arvioimalla yhdessä yksittäisten maiden kiireessä hyväksymää lakia. Yhteisestä arvioinnista saadaan yksittäisten maiden kokemuspohjaa laajempi käsitys.

Uuden lainsäädännön valmistelussa tehtävä pohjoismainen yhteistyö voi ehkäistä rajaesteitä. Pysyvä pohjoismainen oikeusyhteistyö helpottaa haittoja ja epämiellyttäviä yllätyksiä aiheuttavien rajaesteiden poistamista ja antaa paremman turvan maiden rajoja ylittäville pohjoismaalaisille. Se helpottaa myös maiden rajat ylittävää liikkuvuutta ja yhteistyötä sekä elinkeinoelämän ja julkisten viranomaisten yhteistyötä. Lainsäädännön yhtenäinen rakenne parantaa sääntöjen avoimuutta, vaikka sääntöjen lähtökohdissa onkin eroja, ja voi siten vähentää yritysten rajat ylittävään toimintaan liittyviä kustannuksia. Vaikka säännöt eivät ole identtisiä, yhteiset lähtökohdat ja pääsäännöt antavat usein hyvän käsityksen muusta sisällöstä. Pohjoismainen oikeusyhteistyö vahvistaa pohjoismaista mallia ulospäin. Kun mallia yhteisesti selvennetään tietyllä alalla, se voidaan esitellä yhteisenä ideana tai ehdotuksena eurooppalaisissa tai kansainvälisissä neuvotteluissa, mikä parantaa mahdollisuuksia päästä eniten Pohjoismaiden näkemyksiä myötäilevään kansainväliseen yksimielisyyteen.

\section{Yhteistyötä sääntöjen laadinnan eri vaiheissa}

Pohjoismaiden yhteistyötä voidaan vahvistaa sääntöjen laadinnan useissa vaiheissa. Vahvistamisen mahdollisuuksia on:

- eurooppalaisten tai kansainvälisten instrumenttien valmistelussa

- kansallisen lainsäädännön valmisteluvaiheessa joko vapaalta pohjalta tai eurooppalaisten tai kansainvälisten instrumenttien toimeenpanemiseksi

- maan uutta lainsäädäntöä koskevassa kokemusten vaihdossa ja sen arvioinnissa, jossa tavoitteena on antaa muille Pohjoismaille parempi pohja samanlaisten sääntöjen käyttöönoton arviointiin tai kyseistä asiaa koskevien muiden ratkaisuiden löytämiseen.

\section{Kaikkien maiden tai muutaman maan välinen yhteistyö}

Pohjoismaisen yhteistyön tulee olla avointa kaikille maille. Yhteistyöstä voi olla hyötyä osallistujille, vaikkeivät kaikki maat osallistukaan siihen. Tämä johtuu siitä, että poliittiset ja lainsäädännölliset prioriteetit vaihtelevat maasta toiseen, eikä aktiivinen yhteistyö tietyssä asiassa sovi aina välttämättä kaikille maille. Rajallisemmankin yhteistyön tuloksesta voi olla yhtä lailla hyötyä maalle, joka on jättäytynyt kyseisen alan konkreettisen yhteistyön ulkopuolelle. 


\section{Priorisoidut ehdotukset}

Sekä työn alkuvaiheessa että myöhemmin on päätettävä priorisoitavista toimista, jotka valitaan monista pohjoismaisen oikeusyhteistyön laajennusmahdollisuuksista. Mikäli tavoitteet ovat pelkkää tiedon ja kokemusten vaihtoa korkeammalla tasolla ja koskevat lainsäädännöllisiä toimia, priorisointeihin on tärkeää sitoutua poliittisesti. Laajoja lainsäädännöllisiä toimia tulee sen vuoksi priorisoida Pohjoismaiden neuvostossa tai alakohtaisessa ministerineuvostossa.

Priorisointi vaikuttaa kyseistä asiaa koskevan oikeusyhteistyön tavoitteisiin, osallistujamailta odotettavan seurannan laatuun sekä varojen jakautumiseen Pohjoismaiden ministerineuvoston budjetissa.

Tarvitaan hallinnollisia rakenteita ja prosesseja, joiden myötä pohjoismaista yhteistyötä on helpompi käynnistää konkreettisten mahdollisuuksien osalta. Konkreettisista toimista pitää saada pohjoismaista hyötyä joko rajaesteitä torjumalla ja Pohjoismaiden liikkuvuutta helpottamalla tai laatimalla parempaa säännöstöä tai helpottamalla yksittäisen maan lainsäädäntötyötä. Pohjoismaista hyötyä voidaan saada myös siten, että toimet edistävät pohjoismaista mallia tai kansainvälistä ratkaisua.

Lisäksi tulee ottaa huomioon, onko kyse ajankohtaisesta yhteiskunnallisesta aiheesta ja onko jo olemassa hyvä tietopohja jatkopohdintoja varten.

Oikeusyhteistyön tulee koskea

- uusia ja ajankohtaisia yhteiskuntaongelmia, jotka edellyttävät oikeudellisia ratkaisuja lainsäödännön kautta

- nykyisen yhteispohjoismaisen lainsäädännön ylläpitoa ja sopeuttamista uusiin olosuhteisiin

- maiden aloitteisiin pohjautuvia lainsäädännöllisiä toimia

- EU-sääntöjen sekä kansainvälisten yleissopimusten kehittämistä ja täytäntöönpanoa, mikäli ne edellyttävät toimia maiden lainsäädännössä

- uuden lainsäädännön valmistelua ja nykyisen lainsäädännön arviointia.
Tämän perusteella olen laatinut seuraavat ehdotukset:

EHDOTUS 1: POHJOISMAIDEN NEUVOSTON TULEE TEHDÄ KONKREETTISIA OIKEUSYHTEISTYÖN ALOITTEITA (LIITE 1 KOHTA 1)

Pohjoismaiden neuvoston päätös - suositus - konkreettisista oikeusyhteistyön toimista luo poliittista sitoutumista, antaa toimille painoarvoa ja edistää niiden priorisointia ministerineuvostojen ja hallitusten työssä. Tämä on erityisen tärkeää, kun on kyse isommista toimista tai ristiriitaisista aiheista. Jotta Pohjoismaiden neuvoston antamiin suosituksiin saadaan vahvempaa sitoutumista, jokaisen ministerineuvoston tulee laatia kahdesta kolmeen priorisoitua pohjoismaista oikeusyhteistyötä koskevaa ehdotusta, joita maiden parlamentit voivat kommentoida ennen niiden esittelyä Pohjoismaiden neuvostolle.

\section{EHDOTUS 2: PARANNETAAN POHJOISMAISEN OIKEUSYHTEISTYÖN PERUSTAA PÄIVITETYN TIEDON JA SELKEIDEN PÄÄTÖSTEN KAUTTA}

Jotta pohjoismainen oikeusyhteistyö olisi ajankohtaista ja tarkoituksenmukaista, sitä tulee tehdä päivitetyn tiedon ja priorisointien pohjalta. Maiden on otettava varhaisessa vaiheessa joko virkamiestasolla tai tarvittaessa poliittisesti kantaa siihen, otetaanko aihe seurantaan pohjoismaisessa oikeusyhteistyössä. Se edellyttää, että

- Pohjoismaiden ministerineuvosto laatii katsauksen yhteispohjoismaisesta lainsäädännöstä (liite 1 kohta 3 )

- Pohjoismaiden ministerineuvosto seuraa jatkuvasti Euroopan unionin lainsäädäntöaloitteita, jotka voivat vaikuttaa Pohjoismaiden lainsäädäntöön (liite 1 kohta 5)

- maat tiedottavat varhaisessa vaiheessa muille maille suunnitelluista lainsäädännöllisistä toimista asiaa käsittelevän virkamieskomitean kautta

- virkamieskomiteat - ja mahdollisesti yksittäiset ministerineuvostot - päättävät päivitetyn tiedon pohjalta aiheen mahdollisesta seuran- 
nasta pohjoismaisessa oikeusyhteistyössä sekä työn tavoitetasosta (liite 1 kohdat 6, 7, 8 ja 9).

\section{EHDOTUS 3: EHKÄISTÄÄN KANSALLISISTA LAKIMUUTOKSISTA AIHEUTUVIA RAJAESTEITÄ (LIITE 1 KOHTA 2)}

Kansallisissa lainsäädäntöprosesseissa huomio kiinnittyy usein oman maan oloihin, ja mahdolliset vaikutukset muihin pohjoismaalaisiin ja Pohjoismaihin unohtuvat helposti. Sen vuoksi kaikkien maiden tulee

- antaa varhaisessa vaiheessa tietoa muille Pohjoismaille Helsingin sopimuksen artiklan 41 mukaisesti, mikäli ne harkitsevat merkittävää muutosta yhteispohjoismaiseen lainsäädäntöön

- varmistaa lainvalmistelun suuntaviivoissa, että muihin pohjoismaalaisiin ja Pohjoismaihin kohdistuvia vaikutuksia arvioidaan tarpeen mukaan.

Aloilla, joilla on useita erilaisia, erikseen vaikeasti ratkaistavissa olevia rajaesteitä, Pohjoismaiden ministerineuvoston tulee järjestää pohjoismaisia neuvotteluja kyseisiä rajaesteitä koskevan yhteisen arvion pohjalta.

\section{EHDOTUS 4: POHJOISMAISEN SÄÄNNÖSTÖN PAREMPI SAATAVUUS}

Pohjoismaiset yleissopimukset ja yhteispohjoismainen lainsäädäntö on tunnettava paremmin, jotta EU-säädöksiä ei ymmärrettäisi eri tavoin eri Pohjoismaissa sen mukaan mille kielelle ne on käännetty. Sen vuoksi Pohjoismaiden ministerineuvoston tulee

- julkaista painettu ja digitaalinen kooste pohjoismaisista yleissopimuksista (liite 1 kohta 9)

- tehdä aloite pohjoismaisesta oikeustieteen sanastosta (liite 1 kohta 9)

- tehdä aloite uusien EU-säädösten käännösten koordinoinnista (liite 1 kohta 7).

\section{EHDOTUS 5: DIGITALISAATIO}

Pohjoismaista digitalisaatioyhteistyötä priorisoidaan ja sitä käsitellään kolmivuotisessa digi- talisaatioministerineuvostossa (MR-DIGITAL). Digitaalinen viestintä ja transaktiot edellyttävät niitä koskevaa yhteispohjoismaista lainsäädäntöä eurooppalaisessa puitekehyksessä, jotta vältytään digitaalisilta rajaesteiltä. Digitalisaation hyödyntämiseen tähtäävien muiden pohjoismaisten toimien lisäksi onkin käynnistettävä samanaikaisesti lainsäädäntöä koskevaa pohjoismaista yhteistyötä (liite 2 kohta 8). Lainsäädäntötoimia voidaan tarkastella myös yhdessä muiden alojen toimien kanssa, kuten esimerkiksi toisessa Pohjoismaassa annettujen sähköisten reseptien hyväksymisen yhteydessä (liite 2 kohta 12).

\section{EHDOTUS 6: TERVEYS (LIITE 2 KOHTA 12)}

Terveydenhuoltopalvelut ovat keskeinen osa pohjoismaista hyvinvointivaltiota, ja oikeussäännöt vaikuttavat niihin entistä enemmän. Könbergin laatiman Terveysalan pohjoismainen yhteistyö tulevaisuudessa -raportin seurannassa tulee varmistaa myös Pohjoismaiden terveydenhuoltopalveluja koskevan lainsäädännön hyvä pohja. Sen vuoksi tulee muun muassa

- tehdä pohjoismainen arviointi potilaan oikeuksia koskevasta lainsäädännöstä

- selvittää lainsäädäntötoimia, joilla voidaan varmistaa Pohjoismaiden terveydenhuoltopalveluiden hyvä käyttö maiden kaikkien asukkaiden parhaaksi erityisesti erityistason tai kokeellisessa hoidossa sekä palveluiden saatavuudessa naapurimaasta raja-alveilla

- selvittää, voiko lääkkeiden kehittämisen ja ostojen parissa tehtävä pohjoismainen yhteistyö - lainsäädäntötoimineen - parantaa lääkkeiden saatavuutta ja alentaa niiden hintoja

- varmistaa pääsy muiden Pohjoismaiden kaikkiin tietoihin, joilla voi olla merkitystä terveydenhuoltohenkilöstön palkkaamisessa.

\section{EHDOTUS 7: OSAKEYHTIÖITÄ KOSKEVA LAINSÄÄDÄNTÖ (LIITE 2 KOHTA 2)}

Integroituneen Pohjolan elinkeinoelämä hyötyy siitä, että osakeyhtiöitä koskevan lainsäädännön rakenne ja sisältö ovat mahdollisimman yhtenäisiä. Tämän avulla voidaan lisäksi vahvistaa yrityksen 
hallinnointi- ja ohjausjärjestelmän pohjoismaista mallia kansainvälisestä näkökulmasta. Pohjoismaiden aktiivinen asiantuntijayhteisö voidaan osallistaa oikeusyhteistyöhön. Tässä yhteydessä tulee

- laatia ehdotus yhteispohjoismaiseksi osakeyhtiölaiksi, jolla on yhteinen rakenne ja joka perustuu nykyisiin sääntöihin

- $\quad$ selvittää, miten osakeyhtiölaki tulee muotoilla kestävän kehityksen edistämiseksi vihreään talouteen siirtymisen pohjalta

- laatia arviointi eri maissa tehdyistä osakeyhtiöitä koskevista lainsäädäntötoimista innovaatioiden ja yritysten perustamisen edistämiseksi.

\section{EHDOTUS 8: AVOLIITTO (LIITE 2 KOHTA 13)}

Perheoikeuden alalla on ollut paljon yhteispohjoismaista lainsäädäntöä, joka on ajan mittaan eriytynyt jonkin verran. Alan vankan tietopohjan perusteella lähentyminen on mahdollista sisältäen kuitenkin samalla maiden omat tärkeiksi kokemat periaatteelliset erityispiirteet. Toiseen Pohjoismaahan muuttaville perheille ja yksittäisille henkilöille on tärkeää, ettei lainsäädäntö aiheuta heille tarpeettomia yllätyksiä mahdollisesti pitkän ajan päästä. Useimmissa Pohjoismaissa ei ole pääosin lainkaan säännöksiä avopuolisoiden taloudellisesta suhteesta, mutta maiden yhteisen tietopohjan perusteella voidaan arvioida tarvetta yhteispohjoismaiseen lainsäädäntöön. Perheoikeuden alalla voi sen vuoksi olla luonnollista

- $\quad$ selvittää ehdotusta avopuolisoiden taloudellista suhdetta koskevaksi yhteispohjoismaiseksi laiksi.

\section{EHDOTUS 9: ULKOMAALAISLAINSÄÄDÄNTÖ (LIITE 2 KOHTA 10)}

Yksi pohjoismaisten yhteiskuntien suurimmista haasteista liittyy maahanmuttoon ja maahanmuuttajien kotoutumiseen yhteiskuntaan. Ulkomaalaislainsäädäntöä koskevat näkemykset ja ratkaisut vaihtelevat Pohjoismaissa, mutta tietyt kansainväliset yleissopimukset sitovat niitä kaikkia. Tämä mahdollistaa sen, että maat voivat oppia toisiltaan. Vaikka maahanmuuttokysymyksistä voi olla erilaisia poliittisia näkemyksiä, yksittäisen maan on kuitenkin vältettävä kuormittamasta muita Pohjoismaita. Tämän pohjalta tulee

- arvioida pohjoismaisesta näkökulmasta, millaisia vaikutuksia maiden ulkomaalais- ja maahanmuuttolainsäädännön erilaisilla ratkaisuilla on ollut

- arvioida pohjoismaisen yhteistyön puitteissa, miten kansainvälisiä velvoitteita tulee ymmärtää ja panna täytäntöön kansallisessa lainsäädännössä

- arvioida, miten Pohjoismaiden ulkomaalaislainsäödäntöä voidaan sopeuttaa toisiinsa.

\section{EHDOTUS 10: VAHVISTETAAN OIKEUS- YHTEISTYÖTÄ RIKOSOIKEUDEN ALALLA (LIITE 2 KOHTA 15)}

Pohjoismaat voivat oppia toisiltaan inhimillisen ja tehokkaan rikosoikeuden aikaansaamiseksi. Rikollisuuden kehityksen ja uusien kansainvälisten sääntöjen seurauksena on laadittu uusia erilaisia rikostutkintamenetelmiä ja rangaistusmääräyksiä, joita on syytä arvioida. Rajat ylittävän rikollisuuden ja tuomioiden täytäntöönpanon osalta on pohdittava rikostutkinnan aikana tehtyjen päätösten vastavuoroista tunnustamista ja mahdollisesti yhteispohjoismaisen syyttäjäviranomaisen käyttöä tietyissä asioissa. Internetin ja digitalisaation myötä uudenlainen ei-toivottu toiminta on lisääntynyt, ja siinä yhteydessä on pohdittava keinoja tehokkaiden rangaistusmääräysten muotoilemiseksi (liite 2 kohta 9). Jos tällaisia asioita joudutaan ratkomaan kansainvälisesti, pohjoismainen foorumi antaa siihen paremman pohjan kuin pelkät kansalliset pohdinnat.

EHDOTUS 11: KANSAINVÄLISTEN, ETENKIN IHMISOIKEUKSIA KOSKEVIEN, YLEISSOPIMUSTEN TÄYTÄNTÖÖNPANO (LIITE 2 KOHTA 16)

Pohjoismaat painottavat politiikassaan suuresti perustavien ihmisoikeuksien kunnioittamista, ja ne ovat allekirjoittaneet useita ihmisoikeuksia koskevia yleissopimuksia. Niissä oikeudet ja velvollisuudet saatetaan usein mainita yleisesti ja 
epätarkasti ja ne kuuluvat eri hallintoviranomaisten vastuulle. Yleissopimusten ymmärtäminen ja täytäntöönpano käytännössä herättääkin monia kysymyksiä ja niitä on usein punnittava suhteessa yhteiskunnan muihin tärkeisiin kysymyksiin, jotka eivät välttämättä kuulu yleissopimuksesta vastaavalle elimelle. Sen vuoksi pohjoismaisessa yhteistyössä on hyödyllistä pohtia, miten

- yleissopimusten määräyksiä voidaan panna tarkoituksenmukaisesti täytäntöön Pohjoismaissa

- Pohjoismaat voivat mahdollisesti vaikuttaa ja miten niiden tulee suhtautua hallintoviranomaisten käytäntöön yleissopimusten mukaisesti

- ihmisoikeuksia voidaan vaalia muiden alojen yleissopimusten velvoitteiden yhteydessä.

EHDOTUS 12: POHJOISMAINEN LAKINEUVOSTO (LIITE 1 KOHTA 11)

Ruotsin lakineuvoston kaltainen yhteispohjoismainen neuvosto voisi antaa lausuntoja Pohjoismaiden neuvostolle, parlamenteille ja hallituksille siitä, millaisia vaikutuksia yksittäisen maan lakiesityksellä tai lakimuutoksella voi olla rajaesteiden ja Pohjoismaiden integraation kannalta. Lakineuvoston lausunnot voivat siten estää uusien rajaesteiden syntymistä ja edistää sääntömuutoksista johtuvien rajaesteiden ratkaisemista.

\section{EHDOTUS 13: POHJOISMAISESTA} OIKEUSMALLISTA TIEDOTTAVA LAITOS (LIITE 1 KOHTA 12)

Kansainvälisestä näkökulmasta pohjoismainen oikeusmalli on erityinen ja se voi toimia mielenkiintoisena vaihtoehtona muille maille, joiden tavoitteena on kehittää korkeaa turvallisuustasoa ja hyvinvointia edustava demokraattinen oikeusvaltio. Jotta muut maat voivat harkita pohjoismaisen mallin hyödyntämistä, Pohjoismaiden on välitettävä tietoa mallista tuoden samalla esille sen eri toteutustapoja. Se on helpompi toteuttaa ja kansainvälinen uskottavuus paranee, mikäli Pohjoismaat toimivat yhdessä.
Kaikkia ehdotuksia syvennetään tietyssä määrin liitteissä 1 ja 2. Niissä käsitellään myös pohjoismaisen oikeusyhteistyön muita mahdollisia toimenpide-ehdotuksia etenkin ajankohtaisilla lain aloilla. Myös muut kuin liitteessä 2 mainitut lainsäädäntöyhteistyön toimet ovat mahdollisia. Näitä mahdollisuuksia voidaan hyödyntää ehdotusten 1-3 sisältämien uusien yhteistyökäytäntöjen kautta.

Ehdotusten mahdollisissa toteutusaikatauluissa on eroja. Sama koskee myös ehdotukseen sisältyviä eri kohtia. Ehdotus 2 (päivitetty tieto) ja ehdotus 4 (pohjoismaisen lainsäädännön parempi saatavuus) voidaan toteuttaa välittömästi. Ehdotukset 1 ja 3, joihin liittyvät myös Pohjoismaiden neuvosto ja maiden hallitukset, sisältävät käytännön muutoksia, joihin on varattava hieman enemmän aikaa. Ehdotus 5 (digitalisaatio) on toteuttavissa nopeasti osana MR-DIGITALin työtä. Myös ehdotus 8 (avoliitto) on toteuttavissa nopeasti, koska alalla on jo vakaa tietopohja. Ehdotus 6 (terveys), ehdotus 7 (osakeyhtiöt), ehdotus 9 (ulkomaalaislainsäädäntö) ja ehdotus 10 (rikosoikeus) tarvitsevat todennäköisesti vielä lisäsuunnittelua ennen toteutusta. On päätettävä yhteistyössä käsiteltävistä konkreettisista kohdista tai koottava selvitysryhmä, joka ei edellytä ministeriöiden osallistumista. Sama koskee myös ehdotusta 11 (kansainvälisten yleissopimusten täytäntöönpano). Työ voidaan kuitenkin aloittaa välittömästi asian viemiseksi ministerineuvostoon tai Pohjoismaiden neuvostoon, ja ehdotusta 6 (terveys) voidaan puolestaan tarkastella Könbergin raportin seurannan yhteydessä. Ehdotukset 12 ja 13 edellyttävät uusia laitoksia, joten ne ovat ajankohtaisia vasta hieman myöhemmin. 


\section{Liite 1: Yleisiä toimia pohjoismaisen oikeusyhteistyön vahvistamiseksi}

\section{Pohjoismaiden neuvoston tulee tehdä konkreettisia oikeusyhteistyön aloitteita}

Pohjoismaisen oikeusyhteistyön pohjana on usein ollut Pohjoismaiden neuvoston päätös (suositus). Päätösten valmistelussa on ollut eroja, mutta Pohjoismaiden neuvoston päätökset konkreettisista oikeusyhteistyön aloitteista luovat poliittista sitoutumista, antavat aloitteille painoarvoa ja edistävät niiden priorisointia ministerineuvostojen ja hallitusten työssä.

Pohjoismaiden neuvoston arviointien ja päätöksenteon pohjan vahvistamiseksi voi olla tarkoituksenmukaista, että jokainen ministerineuvosto esittää kahdesta kolmeen pohjoismaista (oikeus)yhteistyötä koskevaa priorisoitua ehdotusta, joista maiden parlamentit voivat antaa lausuntonsa ennen niiden esittelyä Pohjoismaiden neuvostolle. Näin ehdotuksia voidaan arvioida tietyssä määrin poliittisesti ja alakohtaisesti ennen kuin niitä käsitellään Pohjoismaiden neuvostossa. Ministerineuvoston ja maiden osallistuminen työhön tällä tavalla ennen Pohjoismaiden neuvoston päätöstä edistäisi todennäköisesti päätöksen tehokasta seurantaa. Lisäksi Pohjoismaiden neuvoston työhön osallistuvat edustajat voivat seurata Pohjoismaiden neuvoston suosituksia.

Pohjoismaiden neuvoston asema vahvistuu entisestään, mikäli työhön saadaan varoja pohjoismaisista budjeteista sen takia, että neuvosto priorisoi oikeusyhteistyön toimia.

\section{Pohjoismainen näkökulma kansallisessa lainvalmistelussa}

Kaikkien Pohjoismaiden lainvalmistelua koskevien sääntöjen ja suuntaviivojen tulee sisältää määräyksiä, joiden tavoitteena on varmistaa, että lakiesitystä arvioidaan tarvittaessa pohjoismaisesta näkökulmasta.
Mikäli alalla on yhteispohjoismaista lainsäödäntöä, tulee varmistaa, että asiasta tiedotetaan muille Pohjoismaille Helsingin sopimuksen artiklan 41 mukaisesti (vrt. kohta 4). Samoin yhteispohjoismaisten sääntöjen säilyttämisestä saatavaa hyötyä tulee verrata syihin, jotka puoltavat uuden kansallisen erityisratkaisun laatimista.

Muissa tapauksissa tulee arvioida, aiheutuuko lakiesityksestä esteitä tai haittoja maiden rajojen yli toimiville pohjoismaalaisille tai yrityksille. Mitä tapahtuu, kun Pohjoismaiden asukas matkustaa naapurimaahan? Mitä tapahtuu, kun maahamme tulee toisen Pohjoismaan asukas? Mikäli lakiesityksen säätelemällä toiminnalla on vaikutuksia muihin Pohjoismaihin, tulee arvioida sen merkitystä lakiesityksen sisällön kannalta tai varmistaa, että lakiesityksen vaikutukset vastaavat täysin kansallisia vaikutuksia. Tämä näkökulma tulee sisällyttää uusien lakiesitysten vaikutusten arviointiin.

Kansallisia lakiesityksiä arvioidaan yleensä EU- ja Eta-oikeuden sekä Schengenin säännöstön asettamien vaatimusten valossa. Pitäisi olla itsestään selvää, että samoin toimitaan pohjoismaisten näkökohtien osalta Helsingin sopimuksen nojalla. ${ }^{2}$

\section{Pohjoismainen katsaus yhteispohjoismaisesta lainsäädännöstä}

Pohjoismaiden ministerineuvoston tulee virkamieskomiteoiden kautta tai muulla tavalla laatia katsauksia yhteispohjoismaisesta lainsäädännöstä, jota koskee Helsingin sopimuksen vaatimus tiedottaa muille Pohjoismaille ennen kuin maa hyväksyy merkittäviä muutoksia lainsäädäntöön (Helsingin sopimuksen artikla 41). Näin saadaan tehokas ja yhtenäinen tiedottamiskäytäntö ja ehkäistään pohjoismaisen lainsäädännön eriytymistä ajan mittaan. Katsausten tulee sisältää lakeja, joita on aikanaan laadittu pohjoismaisen yhteistyön

\footnotetext{
2. Islantia ja Färsaaria lukuun ottamatta asiasta on vain vähän kirjallisia ohjeita. Tutustu Färsaarten maakuntahallituksen tanskankieliseen kiertokirjeeseen "om opsætning og ændring af lagtingslove og bekendtgørelser, om opsætning af rigslovsindstillinger og om opsætning af beslutningsforslag fra Landsstyret/regeringen" (2015), punkt 1.2.2.9 Grænsehindringer.
} 
puitteissa, vaikka laki olisi yhdessä tai useammassa maassa korvattu uudella lailla.

\section{Varhainen ilmoitus Helsingin sopimuksen artiklan 41 mukaisesti}

Helsingin sopimuksen artiklan 41 mukaan maan tulee tiedottaa lainvalmistelun varhaisessa vaiheessa, mikäli se harkitsee pohjoismaiseen yhteistyöhön pohjautuvan kansallisen lainsäädäntönsä määräysten muuttamista. Silloin on mahdollista arvioida, tuleeko muutosta valmistella pohjoismaisen yhteistyön puitteissa, jos esimerkiksi useammalla maalla on vastaavia muutostarpeita. Vaihtoehtoisesti muut maat saavat mahdollisuuden joko seurata yhden maan päättämän lakimuutoksen valmistelua ja täytäntöönpanoa tai vaatia, ettei lakia tule hyväksyä pohjoismaisen näkökulman takia.

\section{Kansallisia lainsäädäntöaloitteita koskevat varhaiset katsaukset virkamieskomiteoissa}

Virkamieskomiteoiden tulee saada oman alansa katsauksia maissa valmisteltavista kansallisista lainsäädäntötoimista. Katsaus on laadittava lainsäädäntötyön hyvin varhaisessa vaiheessa, jotta pystytään realistisesti arvioimaan, olisiko tarkoituksenmukaista käynnistää jonkinmuotoista pohjoismaista oikeusyhteistyötä. Se tarkoittaa esimerkiksi, että maan tulee tiedottaa muille maille suunnitelmistaan asettaa lain valmisteluelin.

\section{Pohjoismainen katsaus EU:n ja Etan lainsäädäntöaloitteista}

Pohjoismaiden ministerineuvoston tulee laatia katsaus mahdollisesti Pohjoismaihin vaikuttavista Euroopan unionin lainsäädännöllisistä aloitteista ja huolehtia katsauksen säännöllisestä päivittämisestä. Katsauksen perusteella pystytään arvioimaan pohjoismaisen oikeusyhteistyön tarvetta uusien säädösten valmistelussa tai täytäntöönpanossa.

\section{EU- ja Eta-sääntöjä koskeva pohjoismainen oikeusyhteistyö}

Virkamieskomiteoiden - ja tarvittaessa ministerineuvostojen - tulee pohjoismaisen EU-lainsäädäntöaloitteita koskevan katsauksen pohjalta arvioida yhteistyön tarvetta uusien EU-säädösten valmistelussa sekä niiden täytäntöönpanossa kansalliseen lainsäädäntöön. Tämä merkitsee ministerineuvoston työn jatkoseurantaa Suomen vuonna 2016 puheenjohtajakaudellaan tekemän aloitteen mukaisesti. $^{3}$

Valmisteluvaiheen yhteistyöllä pohjoismaista mallia tai sitä koskevia yhteispohjoismaisia näkemyksiä voidaan tuoda paremmin esille. Sopivana ajankohtana EU-valmistelun varhaisessa vaiheessa esiteltävä perusteellisesti valmisteltu ehdotus voi saada paljon vaikutusvaltaa.

Viimeistään säädöksen lopullisen hyväksymisen jälkeen tulee harkita pohjoismaista yhteistyötä säädöksen täytäntöönpanossa tavoitteena varmistaa yhtenäinen täytäntöönpano ilman tarpeettomia kansallisia eroja. Täytäntöönpanossa tehtävä yhteistyö, jossa yhdellä maalla on päävastuu, voi helpottaa muiden Pohjoismaiden työtaakkaa. Aloilla, joilla Pohjoismailla on yhtenäinen lakirakenne ja joilla pannaan usein täytäntöön uusia EU- ja Eta-säädöksiä, tulee asettaa pysyviä asiantuntijaryhmiä laatimaan täytäntöönpanoa koskevia ehdotuksia.

Koska täytäntöönpanoa koskeva pohjoismainen yhteistyö ei välttämättä ole tarkoituksenmukaista kaikkien säädösten kohdalla, asiasta voi päättää puheenjohtajamaa ${ }_{1}^{4}$ asianomainen ministerineuvosto tai virkamieskomitea. ${ }^{5}$ Pohjoismaiden neuvostolle on esitetty jäsenehdotus (A 1743/presidiet) pohjoismaisesta yhteistyöstä vaikutusten arvioinnin parissa tavoitteena välttää uusien EU- ja Eta-säädösten aiheuttamia rajaesteitä.

\footnotetext{
3. Vrt. yhteistyöministereiden (MR-SAM) päätös 1. marraskuuta 2016 (kokouksen päiväjärjestyksen kohta 54/16).

4. Pohjoismaiden neuvostossa tehdyn jäsenehdotuksen (A 1630/näring) mukaisesti.

5. Norjan yhteistyöministerin 7. kesäkuuta 2017 päivätty kirje ministerineuvostoille ja virkamieskomiteoille.
} 


\section{Uusien EU- ja Eta-säädösten käännösten koordinointi}

EU- ja Eta-säännökset julkaistaan todistusvoimaisina versioina Pohjoismaiden viidellä pääkielellä.

Näillä kaikilla todistusvoimaisilla versioilla on sama oikeudellinen arvo. Säännösten mahdolliset kielelliset erot voivat vaikeuttaa säädöksen täytäntöönpanoa ja aiheuttaa oikeudellista epävarmuutta ja eriarvoisuutta. Sen vuoksi on ryhdyttävä toimiin käännösten koordinoimiseksi, jotta tällaisilta kielellisiltä eroilta vältytään, joko tekemällä yhteistyötä yksittäisten käännösten kohdalla tai laatimalla yhteinen terminologinen sanasto käännöstyön tueksi. Pohjoismaisen oikeustieteen sanaston (kohta 10) avulla torjutaan epäyhtenäisen terminologian aiheuttamia yksittäisiä eroja eri Pohjoismaiden säännöissä.

\section{Muiden kansainvälisten ja alueellisten yleissopimusten valmistelu ja täytäntöönpano}

Kun kansainvälisiä yleissopimuksia laaditaan Pohjoismaita yhteisesti kiinnostavilla aloilla, virkamieskomiteoiden tulee edistää pohjoismaista yhteistyötä sopimusten valmistelussa (vrt. Helsingin sopimuksen artikla 33). Neuvotteluissa tai organisaatioissa Pohjoismaita voi edustaa yhdestä maasta tuleva yhteinen edustaja. Kun yleissopimus pannaan täytäntöön kansallisessa lainsäädännössä, virkamieskomitean tulee varmistaa, että se tapahtuu pohjoismaisena yhteistyönä tavoitteena saada aikaan yhtenäinen täytäntöönpano ja rajoittaa resurssien käyttöä maiden täytäntöönpanotyössä.

Yleissopimuksissa, joissa sisältöä selkiytetään ja tarkennetaan kansainvälisten tuomioistuinten tai lainvalvontaviranomaisten ratkaisujen kautta, pohjoismaisesta yhteistyöstä voi olla hyötyä arvioitaessa suhtautumista kyseisiin ratkaisuihin ja mahdollisesti niiden täytäntöönpanoon kansallisessa lainsäädännössä.

\section{Kooste pohjoismaisista yleissopimuksista ja pohjoismainen oikeustieteen sanasto}

Pohjoismaisten yleissopimusten tunnettuutta voidaan lisätä painetulla ja digitaalisella koosteella. ${ }^{6}$ Pohjoismaiset yleissopimukset jäävät helposti tavallisten sopimus- ja yleissopimuskokoelmien ulkopuolelle ja saattavat sen vuoksi jäädä muiden kansainvälisten sopimusten taka-alalle.

Pohjoismainen oikeustieteen sanasto, joka mahdollisesti sisältää kaikki kielet, helpottaa Pohjoismaiden kielten käyttöä pohjoismaisessa oikeusyhteistyössä.

\section{Pohjoismainen lakineuvosto}

Tämän raportin valmistelua koskevissa keskusteluissa esitettiin ajatus "pohjoismaisesta lakineuvostosta". Idean pohjana on kolmesta korkeimman oikeuden tai korkeimman hallinto-oikeuden nykyisestä tai aiemmasta tuomarista koostuva Ruotsin lakineuvosto, joka antaa lausuntoja tietyistä hallituksen lakiesityksistä ennen niiden lopullista esittelyä valtiopäiville. Hallitus päättää suurelta osin itse, mitkä lakiesitykset annetaan lakineuvostolle. Lakineuvoston lausunto ei sido hallitusta, mutta se sisällytetään hallituksen lopulliseen esitykseen.

Pohjoismaisen lakineuvoston päätehtävänä olisi arvioida, aiheuttaako uusi lainsäädäntö rajaesteitä tai poikkeaako se jotenkin muuten tarpeettomasti yhteispohjoismaisesta lainsäädännöstä. Mahdolliseen kokoonpanoon voisi kuulua entinen korkeimman oikeuden tuomari jokaisesta maasta, mutta tätä tulee harkita vielä tarkemmin.

Ei ole realistista vaatia, että lakiesitys annetaan pohjoismaiselle lakineuvostolle ennen sen esittelyä parlamentille, mutta pohjoismainen lakineuvosto voi arvioida asiaa myöhemmin ja antaa sitten lausuntonsa asianomaiselle parlamentille ja Pohjoismaiden neuvostolle. On myös pohdittava lähemmin, kuka voi pyytää tällaista lausuntoa vai

6. Samantyyppinen ehdotus esitettiin Norrbackin Nordbornas rättigheter -raportissa (ANP 2002:719). 
antaako pohjoismainen lakineuvosto lausuntoja omasta aloitteesta. Lausunnon pohjalta voidaan myöhemmässä vaiheessa arvioida lain muuttamista. Voidaan myös harkita sitä mahdollisuutta, että hallitukset saavat esittää lakiesityksen pohjoismaiselle lakineuvostolle ennen kuin se annetaan parlamenttien hyväksyttäväksi.

\section{Pohjoismaisesta oikeusmallista} tiedottava laitos

Kansainvälisesti Pohjoismaita arvostetaan demokraattisina oikeusvaltioina, joita luonnehtivat sosiaalinen rauha, korkea hyvinvoinnin taso ja riippumattomuus suurvalloista. Tämä lisää kiinnostusta pohjoismaista mallia kohtaan ja antaa Pohjoismaille perustan auttaa muita maita konfliktien ratkaisemisessa ja vastaavien tavoitteiden saavuttamisessa. Ruotsin suurlähettiläs, entinen ulkoministeri Jan Eliasson ehdotti Tukholmassa vuonna 2011 pidetyssä 39. pohjoismaisessa lakimieskokouksessa yhteispohjoismaista laitosta tai foorumia globaaliin konfliktinratkaisuun. Tällainen laitos voisi myös välittää tietoa Pohjoismaiden kokemuksiin perustuvista muista yhteiskunnallisista perusarvoista ja oikeudellisista infrastruktuureista. Esimerkkeinä voidaan mainita laajat ja tehokkaat lainsäädäntöprosessit, hyvä hallinto sekä kiinteää omaisuutta koskevat käyttöoikeus- ja rekisteröintijärjestelmät. 


\section{Liite 2: Ajankohtaisia konkreettisia hankkei- ta tietyillä oikeuden ja elämän aloilla}

Ajankohtaisissa konkreettisissa hankkeissa voi olla kyse Pohjoismaille täysin uusista asioista ja aloista, joilla pohjoismaisen yhteistyön tuloksena on aiemmin saatu yhteispohjoismaista lainsäädäntöä, tai aloista, joilla maiden lainsäädäntö on erilaista ja aiheuttaa mahdollisesti rajaesteitä.

Yhteispohjoismaisen lainsäädännön myötä useille aloille on saatu - lähinnä yksityisoikeuden alalla - sääntöjä, jotka olivat pääosin yhtenäisiä Pohjoismaissa. Nämä lait on hyväksytty eri aikoihin 1900-luvulla. Useiden lakien välillä on aiempaa suurempia eroja yksittäisten maiden myöhempien lakimuutosten seurauksena, vaikka Pohjoismaiden maiden rajat ylittävät yhteydet ovat vahvistuneet. Ne voivat aiheuttaa odottamattomia yllätyksiä tai rajaesteitä Pohjoismaiden rajat ylittävälle liikkuvuudelle ja toiminnalle. Sen vuoksi on laadittava tarkistuksia tavoitteena säilyttää yhteispohjoismainen luonne asioissa, joihin ei ole syytä tehdä muutoksia myöhemmin. Tämä onnistuu helpoiten aloilla, joilla tarkistustyön voi suorittaa pohjoismainen asiantuntijayhteisö.

Ajan mittaan maissa tehdyt erilaiset ratkaisut voivat toimia lähtökohtana rakentaville keskusteluille siitä, onko jokin ratkaisuista suositeltavin. Joissakin tapauksissa on luontevaa säilyttää eri säännöt, mutta Pohjoismaiden hyvän oikeustiedon kannalta on kuitenkin yhtä lailla tärkeää sopeuttaa eri säännöt yhteiseen lainsäädännön rakenteeseen.

Joitakin jäljempänä esiin otettavia aloja on jo käsitelty raporteissa, jotka koskevat oikeusyhteistyön ulkopuolisia lähtökohtia (Bo Könberg: Terveysalan pohjoismainen yhteistyö tulevaisuudessa (2014) ja Poul Nielson: Työelämä Pohjolassa. Haasteita ja ehdotuksia (2016)). Näiden lisäksi pohjoismaisen yhteistyön faktiset aiheet nostavat esille lainsäädäntökysymyksiä, joiden kohdalla voi olla syytä harkita pohjoismaista oikeusyhteistyötä. Esimerkki tästä on toimet, jotka kohdistuvat haavoittuvaa luontoa tai infrastruktuuria liikaa kuormittavaan matkailuun - ajankohtainen ongelma etenkin Länsi-Pohjolassa.

\begin{abstract}
1. Sopimuslaki
Pohjoismaiset sopimuslait koskevat yksityishenkilöiden välisiin transaktioihin liittyviä perusasioita ja sisältävät sääntöjä sopimusten tekemisestä, valtakirjasta ja pätemättömistä sopimuksista. $\mathrm{Ne}$ hyväksyttiin vuosina 1915-1920 pohjoismaisen oikeusyhteistyön puitteissa. Lakien tarkistamista aloitettiin 1990-luvulla, mutta työ keskeytyi muun muassa, koska Euroopan unionissa valmisteltiin kuluttajansuojaa koskevia sääntöjä kohtuuttomista sopimuksista (nämä säännöt on sittemmin sisällytetty pohjoismaisiin sopimuslakeihin). Tätä lukuun ottamatta lait ovat pysyneet pääasiassa muuttumattomina eivätkä ne suoraan kata uusia sopimusmuotoja tai vakiosopimuksia, mutta lakien tarkistamisen tarve jakaa mielipiteitä oikeustieteen asiantuntijaympäristöissä.
\end{abstract}

\section{Yhtiölainsäädäntö}

Yhtiölainsäädäntö sisältää lakeja erilaisista yhteenliittymistä (muun muassa osakeyhtiöt, avoimet yhtiöt ja osuuskunnat) ja säätiöistä. Siinä käsitellään elinkeinoelämän organisoitumisen perusasioita. Aiemmat osakeyhtiölait laadittiin pohjoismaisena yhteistyönä yhtenäisten lakien aikaansaamiseksi, mutta nykyinen lainsäädäntö on laadittu kansalliselta pohjalta ja se toteuttaa useita EU-direktiivejä. Pohjoismaiden rajat ylittävälle elinkeinoelämälle on eduksi, että osakeyhtiölain pohjana on yhtenäisiin sääntöihin perustuva yhteinen rakenne. Aktiivinen pohjoismainen asiantuntijaympäristö voi helpottaa tämän tavoitteen saavuttamista, ja Euroopan unionissa meneillään oleva työ voi antaa syyn yhteispohjoismaiseen täytäntöönpanoon.

Keskusteltaessa osakeyhtiöiden yhteiseurooppalaisista säännöistä on tärkeää tuoda esiin yrityksen hallinto- ja ohjausjärjestelmän pohjoismainen malli kansainvälisesti muista erottuvana vaihtoehtona, sillä siinä yhdistyvät enemmistöosakkaiden tehokkaat ohjausmahdollisuudet ja vähemmistöosakkaiden suoja. Konkreettisia kysymyksiä, joissa pohjoismainen kokemusten 
vaihto ja yhteispohjoismaisten sääntöjen pohdinta voivat olla hyödyllisiä yhteisten tavoitteiden saavuttamiseksi, ovat pääomavaatimuksen merkitys yrityksen velkojien suojelemiseksi, johtajien bonusten rajoittaminen, yrityksen elinten sukupuolikiintiöt, kestävän kehityksen mukainen johtamistapa ja erityissäännöt innovaatioiden ja yrittäjyyden edistämiseksi (vrt. osakeyhtiön kevytversio, IVS, Tanskassa). Koska osakeyhtiö on yleisin yhtiömuoto ja koska aiemmin on ollut sitä koskevaa yhteispohjoismaista lainsäädäntöä, pohjoismaista oikeusyhteistyötä on luonnollista vahvistaa osakeyhtiöitä koskevan lainsäädännön parissa.

\section{Rahoitusmarkkinoita ja saatavien perintää koskeva lainsäädäntö}

Pohjoismaiden rahoitusmarkkinoilla on enemmän toimijoita maiden rajojen yli kuin monella muulla alalla. Vaikka rahoituslaitosrakenteessa on eroja, voidaan puhua pohjoismaisista rahoitusmarkkinoista. Sen vuoksi yhteispohjoismainen lainsäädäntö on luonnollinen ratkaisu, mutta alalla on tehty vain vähän pohjoismaista oikeusyhteistyötä viime aikoina. Etenkin rahoituslaitosten osalta lainsäädäntö pohjautuu EU-sääntöihin ilman, että kansallisessa täytäntöönpanossa tehtäisiin erityisesti pohjoismaista yhteistyötä, ja kiinnostus yhteistyötä kohtaan vaikuttaa rajalliselta etenkin ministeriöissä.

Vakuutusyhtiöistä on aiemmin ollut yhteispohjoismaisia lakeja, ja nykyinen vakuutussopimuksia koskeva lainsäädäntö on laadittu pohjoismaisena yhteistyönä. Maksuvälineitä koskevassa yhteispohjoismaisessa lainsäädännössä on aiemmin säädelty vekseleitä ja sekkejä, mutta niiden tilalle on tullut muita maksuvälineitä. Lisäksi vuosina 1935-1940 laaditussa velkakirjalaissa määriteltiin saatavien perinnän keskeiset periaatteet, jotka ovat voimassa osittain vielä nykyäänkin.

Pohjoismaiden markkinoiden yhtenäisyyden edistämiseksi on tärkeää, että rahoituslaitoksia ja -palveluita, mukaan lukien maksupalvelut ja vakuutussopimukset, koskeva EU-säännöstö pan- naan täytäntöön kansallisesti yhtenäisellä tavalla ja että Pohjoismaiden kansallisissa täydentävissä säännöissä ei ole sattumanvaraista vaihtelua. On hyödyllistä pitää voimassa yhteispohjoismaista lainsäädäntöä vakuutussopimuksista ja kehittää rahoitussopimuksia koskevaa yhteispohjoismaista lainsäädäntöä, joka voi muun muassa taata pohjoismaalaisille mahdollisuuden avata pankkitilin toisessa Pohjoismaassa.

\section{Immateriaalioikeus - teollis- ja tekijänoikeudet}

Immateriaalioikeuden lainsäädännön merkitys kasvaa nykyään yhteiskunnassa ja elinkeinoelämässä. Alalla on ollut yhtenäisiä kansainvälisiin yleissopimuksiin pohjautuvia pohjoismaisia lakeja teollisoikeuksista (patentit, tavaramerkit ja muotoilu) sekä tekijänoikeuksista. Nykyään lainsäädäntö pohjautuu suurelta osin EU-direktiiveihin, eikä se ole luonteeltaan enää niin yhteispohjoismaista kuin aiemmin, ja maiden näkemykset ovat vaihdelleet yksittäisissä kysymyksissä (esimerkiksi bioteknologisten keksintöjen patentoinnista).

Yhteispohjoismainen lainsäädäntö voi yksinkertaistaa uUsien EU-sääntöjen täytäntöönpanoa maissa. Aktiivinen pohjoismainen asiantuntijaympäristö voi edistää yhteispohjoismaisen lainsäädännön aikaansaamista. Tekijänoikeuksien yhteispohjoismainen lainsäädäntö voi tukea pohjoismaista kulttuurivaihtoa, korostaa kollektiivisia oikeuksia muun muassa sopimuslisenssien kautta kansainvälisten sääntöjen kehityksen valossa ja luoda pohjaa tekijänoikeuksien suojaaman aineiston käyttöä koskevalle yhteispohjoismaiselle oikeuksien selvittämiselle.

\section{Henkilö- ja tavaraliikenne}

Merenkulun lainsäädäntö on esimerkki laajasta pohjoismaisesta oikeusyhteistyöstä, jonka tavoitteena on ollut kansainvälisiin yleissopimuksiin, vähitellen myös EU-sääntöihin, perustuva yhtenäinen lainsäädäntö. Liikennealan säännöt koskevat aina tiettyä liikennemuotoa, mikä voi sen vuoksi aiheuttaa ongelmia multimodaaliliikenteen koh- 
dalla. Liikenteenharjoittajien kannalta on tärkeää, että yhden maan pätevyystodistus hyväksytään kaikissa muissa Pohjoismaissa, mikä ei toteudu täysin nykyään.

\section{Työolot}

Työelämän pohjoismainen malli ilmenee eri tavoin työelämän konfliktien ratkaisussa eri Pohjoismaissa. Vähäisempi järjestäytyminen, maahan muuttava työvoima ja muutokset työsopimuksissa voivat vaikuttaa työnantaja- ja työntekijäjärjestöjen aktiiviseen osallistumiseen perustuvaan kolmikantamalliin. Pohjoismaisella tasolla kolmikantamallia voitaisiin vahvistaa työnantajien yhteispohjoismaisella järjestäytymisellä.

Ulkomaankomennuksia ja yritysten omistajanvaihdoksia koskevilla EU-pohjaisilla säännöillä on nykyään suuri merkitys Pohjoismaiden työehtojen ja työsuhdesuojan varmistamisessa. Sosiaalista polkumyyntiä torjuvat toimet ovat ajankohtaisia kaikkialla Pohjoismaissa. Sekä konsernisuhteissa että jakamistaloudessa on pohdittava sitä, ketä pidetään työnantajana ja kenelle työnantajavastuu kuuluu. Franchising-sopimusten itsenäisen elinkeinoharjoittajan asema voi herättää kysymyksiä suojasta, joka muistuttaa työntekijälle kuuluvaa suojaa.

Ammatinharjoittamisen kannalta toisessa Pohjoismaassa saavutetun ammattipätevyyden hyväksyminen on tärkeä kysymys Euroopan unionin ammattipätevyysdirektiivin määräysten lisäksi. Tähän liittyy Färsaaria ja Grönlantia koskevia erityiskysymyksiä. Harjoittelijoiden vaihdon on oltava vapaata Pohjoismaissa (Helsingin sopimuksen artikla 14), mutta sen varmistamiseksi on myös tärkeää tietää, millaisia sosiaaliturvaan pohjautuvia oikeuksia tai vakuutuksia harjoittelijalla tai oppisopimusoppilaalla on naapurimassa esiintyvissä sairaus- ja onnettomuustapauksissa.

\section{Vero-, maksu- ja tulliasiat}

Vero-, maksu- ja tulliasioissa tehdään pohjoismaista ja kansainvälistä yhteistyötä kaksoisverotuksen välttämiseksi ja perinnän varmistamiseksi. Niistä on sovittu pohjoismaisissa ja kansainvälisissä yleissopimuksissa. Pohjoismaiden verolainsäädännön rakenne vaihtelee, ja sen laajaa yhdenmukaistamista on vaikea kuvitella.

Vero- ja maksuhallintojen erot voivat olla esteenä yritysten toiminnalle maiden rajojen yli ja vaikeuttaa yritysten toimintaa raja-alveilla. Asialla on seutupoliittinen ulottuvuus, koska on helpompi pitää raja-alveet asuttuina, mikäli rajat ylittävä toiminta on mahdollista ilman erityistä maksu- ja tai tullivelvollisuutta. Tällaisten rajaesteiden välttämiseksi sääntöjen tietty yhdenmukaistaminen tai maksu- ja tullisääntöjen poikkeukset voivat olla tarpeen. Saattaa olla syytä käydä yhdessä läpi tähän liittyviä ongelmia, sillä ratkaisuun tarvitaan mahdollisesti vastavuoroisia kompromisseja.

Vero- ja maksupetosten torjumisesta on yhteistä etua Pohjoismaille. Sen vuoksi on käyty yhteispohjoismaisia neuvotteluja tiedonvaihtosopimuksista veroparatiisien kanssa. Myös muita veropetosten ja veroparatiisien vastaisia toimia on helpompi toteuttaa pohjoismaisen yhteistyön puitteissa.

\section{Koulutus}

Koulutus on tulevaisuuden yhteiskunnan työllisyyden ja hyvinvoinnin kannalta perustava ala, jonka sääntöjen laatimiseen Euroopan unioni ei ole osallistunut. Pohjoismaisissa yhteyksissä voidaan keskustella etenkin korkea-asteen koulutuksessa koulutussuuntauksien jakautumisesta eri Pohjoismaissa, pohjoismaisten hakijoiden tasa-arvoisuudesta, kun hyväksynnän perusteena käytetään muissa Pohjoismaissa hankittuja pohjatietoja sekä 
oikeudesta opintotukeen muissa Pohjoismaissa opiskeltaessa. Vaikka voi olla toivottavaa sisällyttää nämä asiat lainsäädäntöön - eikä vain asetuksiin -, havaittavissa ei kuitenkaan ole sellaisia rajaesteitä, joiden takia alalla tarvittaisiin vahvistettua pohjoismaista oikeusyhteistyötä. Harjoittelijoille ja oppisopimusoppilaille tarvitaan kuitenkin lisää mahdollisuuksia päästä muihin Pohjoismaihin (vrt. kohta 6).

\section{Digitalisaatio}

Digitalisaatio merkitsee sekä uusia mahdollisuuksia Pohjoismaiden välisessä yhteistyössä että täysin uusia oikeudellisia asioita ja nykyisten sääntöjen ymmärtämistä koskevia kysymyksiä. Digitalisoidun toiminnan potentiaalin hyödyntämiseksi ja rajaesteiden välttämiseksi säännöstöä tulee koordinoida monilta osin. Digitaalisen tunnistamisen vastavuoroinen hyväksyminen ja allekirjoituksen todentaminen ${ }^{7}$ yhteisten vaatimusten mukaisesti luovat edellytyksiä palveluiden digitalisoinnille Pohjoismaiden välillä (esimerkiksi toisessa Pohjoismaassa annetun sähköisten reseptien käyttö), ja lisäksi pohjoismaalaisten on voitava ottaa helposti yhteyttä toisen Pohjoismaan viranomaisiin. Digitalisaation tuomiin mahdollisuuksiin, esimerkiksi älyajoneuvojen käyttöön, saattaa liittyä vastuukysymyksiä, jotka tulee selvittää pohjoismaisella tasolla. Jos kysymyksiin ei saada ratkaisua uusien EU- ja Eta-sääntöjen kautta, digitalisaatioministerineuvoston (MR-DIGITAL) tulee varmistaa, että digitalisaation yhteydessä ratkaistavat lainsäädännölliset asiat tulevat voimaan kaikkialla Pohjoismaissa. Näistä kysymyksistä tulee keskustella ja ne tulee ratkaista samalla tavoin.

Verkossa ja sosiaalisessa mediassa esiintyvästä uhkailusta ja loukkauksista on tullut arkipäiväinen ilmiö myös Pohjoismaissa. Alaa voitaisiin hyvin säännellä pohjoismaisen oikeusyhteistyön kautta ja se voisi muodostaa mallin myös Pohjoismaiden ulkopuolisia maita koskevalle suhteelle.

\section{Kansalaisuus ja maahanmuutto}

Kansalaisuutta koskeva lainsäädäntö on laadittu aiemmin pohjoismaisena yhteistyönä. Myös lainsäädännön myöhemmissä tarkistuksissa on pyritty helpottamaan toisen Pohjoismaan kansalaisuuden saamista pohjoismaalaisille ja rajoittamaan yhden maan kansalaisuusvaatimuksen vaikutuksia, mikäli henkilö on jo yhden Pohjoismaan kansalainen. Tähän liittyen on ehdotettu Pohjoismaiden kaksoiskansalaisuuden myöntämistä tai yhden maan kansalaisuuden lisäksi pohjoismaisen kansalaisuuden käyttöönottoa ilmauksena Pohjoismaihin kuulumisesta. ${ }^{8}$ Mikäli pohjoismainen kansalaisuus otetaan käyttöön, se merkitsisi lainsäädäntömuutosta lain vaikutuksista tehdyn selvityksen pohjalta.

Ulkomaalaisasioista on tullut tärkeä ja kiistanalainen politiikan ala Pohjoismaissa, ja maiden ulkomaalaispolitiikassa on merkittäviä eroja. Sekä maahanmuuton että kotoutumisen osalta tarvitaan lainsäädäntöä. Maan poliittisesta suuntauksesta ja toteutettavista toimista riippumatta lainsäädännön muotoileminen on kaikkien maiden yhteinen asia. Lainsäädännöstä kansainvälisten yleissopimusten valossa saatuja kokemuksia tulee verrata toisiinsa tavoitteena laatia mahdollisimman selkeä lainsäädäntö kunkin maan ulkomaalaispolitiikkaa ja oikeusturvaa koskevien tavoitteiden saavuttamiseksi. Poliittinen tahto alan politiikan ja sääntöjen yhdenmukaistamiseksi voi lisäksi tehostaa turvapaikanhakujärjestelmää ja sen avulla voidaan myös välttää ongelmien siirtämistä yhdestä Pohjoismaasta toiseen. Kotoutumisessa on syytä ottaa mallia muiden Pohjoismaiden kokemuksista, ei pelkästään käytännön

\footnotetext{
7. Vrt. Pohjoismaiden neuvoston suositus 21/2017: Pohjoismaisen sähköisen tunnistamisen käyttöön ottaminen.

8. Ks. Sten Palmgren \& Gunnar Wetterberg: Nordens tid är nu. Förutsättningar och möjligheter med ett nordiskt medborgarskap (2017).
} 
toimissa, vaan myös kotoutumiseen vaikuttavassa tai sitä edistävässä lainsäädännössä.

\section{Hyvinvointipalvelut}

Kaikkien Pohjoismaiden tavoitteena on hyvinvoinnin ja sosiaaliturvan varmistaminen. Alan lainsäädännössä on kuitenkin usein eroja maiden välillä. Erojen takia voi olla epäselvää, onko maiden rajojen yli liikkuva pohjoismaalainen oikeutettu lähtömaansa kaltaiseen sosiaaliturvaan vai samaan sosiaaliturvaan kuin uuden oleskelumaan kansalaiset. Vaikka on selvää, että henkilö on oikeutettu hyvinvointipalveluun, voi kuitenkin olla epäselvää, mille maalle palvelun myöntäminen kuuluu, ja sillä voi olla merkitystä niin palvelun sisällön kuin sen kustannusten kattamisen kannalta. Useimmiten ei ole realistista odottaa eri maiden hyvinvointijärjestelmien yhdenmukaistamista tällaisten kysymysten ratkaisemiseksi, mutta pohjoismaisessa oikeusyhteistyössä pitäisi olla mahdollista löytää ratkaisuja näihin kysymyksiin erilaisten hyvinvointijärjestelmien puitteissa. Tämän ratkaiseminen on edellytys sille, että voidaan taata sama turva Pohjoismaiden rajojen yli liikkuville kuin mihin pyritään yksittäisessä maassa. Monia kysymyksiä säädellään Euroopan unionin sosiaaliturva-asetuksessa ja pohjoismaisissa sosiaaliturva- ja sosiaalipalvelusopimuksissa, ${ }^{9}$ mutta on syytä seurata asiantuntijaryhmän seuraavissa raporteissa dokumentoitua kokonaiskatsausta: Rajaesteet Pohjoismaissa sosiaali- ja työmarkkinakysymyksissä: Rajaesteiden yleiskuvaus ratkaisuehdotuksineen (NORD 2012:002) sekä Arbejdsmarkedspensioner/ Tjänstepensioner i Norden - utmaningar i gränsöverskridande situationer (TemaNord 2011:540).

\section{Terveys}

Toimiva terveydenhuolto on tärkeä osa pohjoismaisia hyvinvointivaltioita. Kyseessä on ennen kaikkea terveydenhoidollinen ja taloudellinen haaste, mutta myös oikeussäännöillä on merkitystä terveydenhuoltopalveluiden saatavuuden edistämisessä lääketieteen tarpeiden mukaisesti.

Terveydenhuollon kysymysten oikeudellistaminen on ollut merkittävä asia potilaan oikeuksien kehittämisessä. Potilaan oikeuksien laajuus tietyssä maassa voi riippua muun muassa taloudellisista oloista. Pohjoismaisissa yhteyksissä kyse on siitä, mikä oikeus - tai mitä mahdollisuuksia potilaalla tulee olla hoidon saamiseen toisessa maassa, kun kustannuksista vastaa asuinmaa. Potilasvahingon korvausvaatimukset käsitellään lähtökohtaisesti hoitomaan oikeuden mukaisesti, mikäli muusta ei ole päätetty.

Lääketieteen erikoisalojen ja resurssien hyödyntämisen takia potilaiden vaihto rajojen yli voi olla toivottavaa etenkin harvinaisten sairauksien tai kokeellisen hoidon kohdalla. ${ }^{10}$ Terveydenhuoltopalveluiden antaminen naapurimaassa voi olla järkevää raja-alueilla. Rajat ylittävän liikkuvuuden edistämiseksi yhdessä maassa annettuja (sähköisiä) reseptejä tulee voida käyttää toisessa Pohjoismaassa.

Koko Pohjolan väestö ja pohjoismaiset terveystiedot voivat antaa terveydenhuoltoalan tutkimuksiin huomattavasti paremman pohjan kuin jos terveystietoja saadaan vain yksittäisestä maasta. Se edellyttää yhteispohjoismaista pääsyä terveystietoihin ja herättää kysymyksen tutkimushankkeiden yhteispohjoismaisesta eettisestä arvioinnista. Samalla tavalla pohjoismaisesta yhteistyöstä voidaan saada parempi pohja uusien lääkkeiden

\footnotetext{
9. Asetus (EY) N:o 883/2004, pohjoismainen sosiaaliturvasopimus (12. kesäkuuta 2014) ja pohjoismainen sosiaalipalvelusopimus (14. kesäkuuta 1994).

10. Vrt. Pohjoismaiden neuvostolle esitetty jäsenehdotus Pohjoismaiden terveydenhuoltojärjestelmien yhteistyön lisäämisestä (A 1752/välfärd).
} 
testaamiseen. Lääkkeiden hyväksymisen ja ostojen parissa tehtävä pohjoismainen yhteistyö voi lisäksi vaikuttaa lääkkeiden hinnoitteluun.

Ammattipätevyyksien vastavuoroisen hyväksymisen perusteella terveydenhuoltohenkilöstön liikkuvuus on suurta Pohjoismaiden välillä. Samanaikaisesti on pyrittävä välttämään, että epäpätevää henkilöstöä siirtyy maasta toiseen. On tarpeen varmistaa, että Pohjoismaan terveydenhuoltoviranomaiset saavat tietoja muiden Pohjoismaiden hallinnollisista reaktioista, vaikkei niissä olisikaan kyse suoranaisesta ammatinharjoittamisen rajoittamisesta. Digitalisaation osalta tämä voidaan saavuttaa yhteispohjoismaista terveydenhuoltohenkilöstöä koskevalla lainsäädännöllä tai yhteispohjoismaisella pääsyllä yksittäisten maiden rekistereihin.

Monia näistä asioista säädellään EU:n ja Etan sekundäärioikeudessa. Niiltä osin kuin asetusten ja direktiivien sisältämä sääntely ei ole valmis, pohjoismaisesta oikeusyhteistyöstä on erityistä hyötyä.

\section{Perhe ja perintö}

Perheoikeuden alalla on tehty laajaa pohjoismaista oikeusyhteistyötä, jonka seurauksena laadittiin muun muassa yhtenäinen avioliittolainsäädäntö.

Eri maiden uudistustarpeet johtivat kuitenkin erilaiseen muutostahtiin, mutta lähtökohdat ovat nyt todennäköisesti paremmat Pohjoismaiden yhteisille pohdinnoille. Perheiden liikkuvuuden kannalta on epäonnista, että säännöissä on merkittäviä tai tarpeettomia eroja erityisesti perhelainsäädännössä. Tähän liittyy myös Färsaaria ja Grönlantia koskevia erityiskysymyksiä.

Pohjoismaiden ministerineuvoston vuosina 1998-2002 toteuttamasta laajasta perhe- ja perintöhankkeesta saatiin eri maiden lainsäädännön sopeuttamisen ja yhdenmukaistamisen pohjaksi aineistoa, joka on edelleen käyttökelpoista. Poh- joismaiden oikeustieteen asiantuntijaympäristössä tehtiin vastaava avoliittoa koskeva selvitys vuonna 2014, ja se sisältää yhteispohjoismaisen lakiluonnoksen. Koska Ruotsilla on ollut oma avoliittolaki vuodesta 1987 (nykyään laki 2003:376), kyseisestä lainsäädännön muutoksesta voi olla hyötyä kaikille muille Pohjoismaille - ne voivat tehdä sen pohjalta empiirisen arvion vaikutuksista. Varojen jako avioliiton tai avoliiton purkamisen tai perinnön yhteydessä voi merkitä epämiellyttäviä yllätyksiä eri maista tuleville osapuolille, ja asiaa olisi hyvä selvittää ja pohtia yhteispohjoismaiselta pohjalta.

Maahanmuutto ja monikulttuuriset yhteiskunnat herättävät uusia kysymyksiä siitä, miten perhelainsäädännössä tulee suhtautua muiden kulttuurien normeihin. Pakkoavioliitot ja lapsiavioliitot vaikuttavat Pohjoismaiden yhteisiin arvoihin.

Hedelmöityshoitojen, sijaissynnytyksen ja (juridisen) sukupuolenkorjauksen vaikutuksia perhelainsäädäntöön, etenkin vanhemmuuteen, voidaan pohtia Pohjoismaiden kesken silloinkin, kun näitä tilanteita koskevat arviot eroavat toisistaan.

\section{Edunvalvonta}

Myös edunvalvontaa koskeva lainsäädäntö on laadittu pohjoismaisena oikeusyhteistyönä. Uudehko lainsäädäntö herättää kysymyksiä muun muassa ennakkovaltakirjojen käytöstä toimintakyvyn alenemisen varalta. YK:n vammaisten henkilöiden oikeuksia koskevan yleissopimukseen liittyy epäselviä kysymyksiä edunvalvonnan käytöstä, ja niitä on hyödyllistä arvioida pohjoismaisessa yhteydessä (ks. myös alla oleva kohta 16).

\section{Rikosoikeus}

Pohjoismaista rikosoikeutta on perinteisesti leimannut inhimillisyys, vaikka toisenlaiset kriminaalipoliittiset suuntaukset ovat saaneet jalansijaa viime vuosina. 
Rikollisuuden kehityksen myötä lainsäätäjät suhtautuvat entistä myönteisemmin salaisten pakkokeinojen käyttöön, mikä voi puolestaan herättää ihmisoikeussopimuksiin liittyviä kysymyksiä. Vakoiluohjelmien käyttö on esimerkki tästä. Terroriteot ovat johtaneet uusiin pakkokeinoihin ja rikoslain määräyksiin, jotka on osin hyväksytty erittäin nopealla aikataululla kansainvälisen painostuksen seurauksena. Tämäntyyppisiin pakkokeinoihin ja rikoslain määräyksiin liittyviä kokemuksia on hyvä pohtia pohjoismaisella tasolla.

Digitalisaatio ja internet mahdollistavat uudenlaisia rangaistavia tekoja. Pohjoismaisen yhteistyön puitteissa voidaan keskustella, miten näitä käsitellään sopivimmalla tavalla rikoslaissa.

Rikoslainkäytössä sekä tutkintavankeuden käyttö että asiankäsittelyn kokonaisaika aiheuttavat ihmisoikeuksiin ja tehokkuuteen liittyviä haasteita. Muiden kokemuksista voi olla tässä paljon hyötyä.

Tehokas tuomioiden täytäntöönpano Pohjoismaiden rajat ylittävässä rikollisuudessa on syy harkita rikostutkinnan päätösten vastavuoroista hyväksymistä. Myös yhteispohjoismaisen syyttäjäviranomaisen käyttöä tietyissä tapauksissa voidaan selvittää pohjoismaisella tasolla.

Pohjoismaiden poliisiresursseja voidaan hyödyntää paremmin rajojen yli, mikäli poliisien pakkokeinojen käyttöön on yhtenäiset säännöt. Resurssien yhteiskäyttö voi koskea sekä harvaan että tiheään asuttuja raja-alueita.

\section{Kansainvälisten ihmisoikeuksia koskevien yleissopimusten täytäntöönpano}

Kaikki Pohjoismaat korostavat kansainvälisten ihmisoikeussopimusten mukaisia arvoja. Yleissopimusten säännöt jättävät usein paljon tilaa tulkinnoille. Yleissopimuksiin sisältyvien arvojen toteuttamisessa voidaan usein joutua pohtimaan, minkä tyyppiset säännöt sopivat tarkoitukseen pohjoismaisissa yhteiskunnissa ja miten niitä tulee punnita suhteessa muihin yhteiskunnallisiin tavoitteisiin. Yleissopimusten tulkinnanvaraisuus on monissa tapauksissa mahdollistanut kansainvälisten yleissopimuselinten päätöksiin ja lausuntoihin perustuvan dynaamisen oikeuskehityksen sekä Pohjoismaita että muita yleissopimuksen jäsenvaltioita koskevissa tapauksissa. Mikä on paras tapa suhtautua tällaiseen käytäntöön kansallisessa lainsäädännössä tai miten voidaan parhaiten vaikuttaa kansainväliseen yleissopimuskäytäntöön, on sekä yleisesti että tiettyjen yleissopimusten ja niiden tiettyjen kohtien osalta aihe, jota tulee käsitellä pohjoismaisessa yhteistyössä. 
Pohjoismaiden ministerineuvoston Nyt Norden -uudistustyön osana laaditaan säännöllisesti strategiaselvityksiä pohjoismaisen yhteistyön mahdollisuuksista. Niissä selvitetään perusteellisesti mahdollisia uusia pohjoismaisia yhteistyöaloja 5-10 vuoden aikavälillä. Tähän mennessä selvityksiä on laadittu energia-, terveys- ja työelämäalalla.

Uudistustyön toisessa vaiheessa havaittiin mahdollisuuksia elvyttää pohjoismaista oikeusyhteistyötä tavoitteena kehittää pohjoismaista yhteistyötä ja vahvistaa Pohjoismaiden integraatiota. Yhteistyöministerit päättivät tältä pohjalta toteuttaa kyseisiä mahdollisuuksia koskevan rajatun analyysin. Sen laatijaksi valittiin Oslon yliopiston emeritusprofessori Inge Lorange Backer. Backerilla on pitkä kokemus oikeusalan pohjoismaisesta yhteistyöstä, ja Norjan oikeusministeriön lakiasiainosaston osastopäällikkönä toimiessaan hän edusti Norjaa Pohjoismaiden ministerineuvoston oikeusyhteistyön virkamieskomiteassa vuosina 1995-2008.

Backerin raportti "Vahvempaa pohjoismaista oikeusyhteistyötä haasteita ja mahdollisuuksia" sisältää pohjoismaisille yhteistyöministereille suunnattuja ulkopuolisen raportoijan ideoita tulevasta oikeusalan pohjoismaisesta yhteistyöstä. Raportti luovutetaan pohjoismaisille yhteistyöministereille helmikuun 2018 kokouksen yhteydessä.
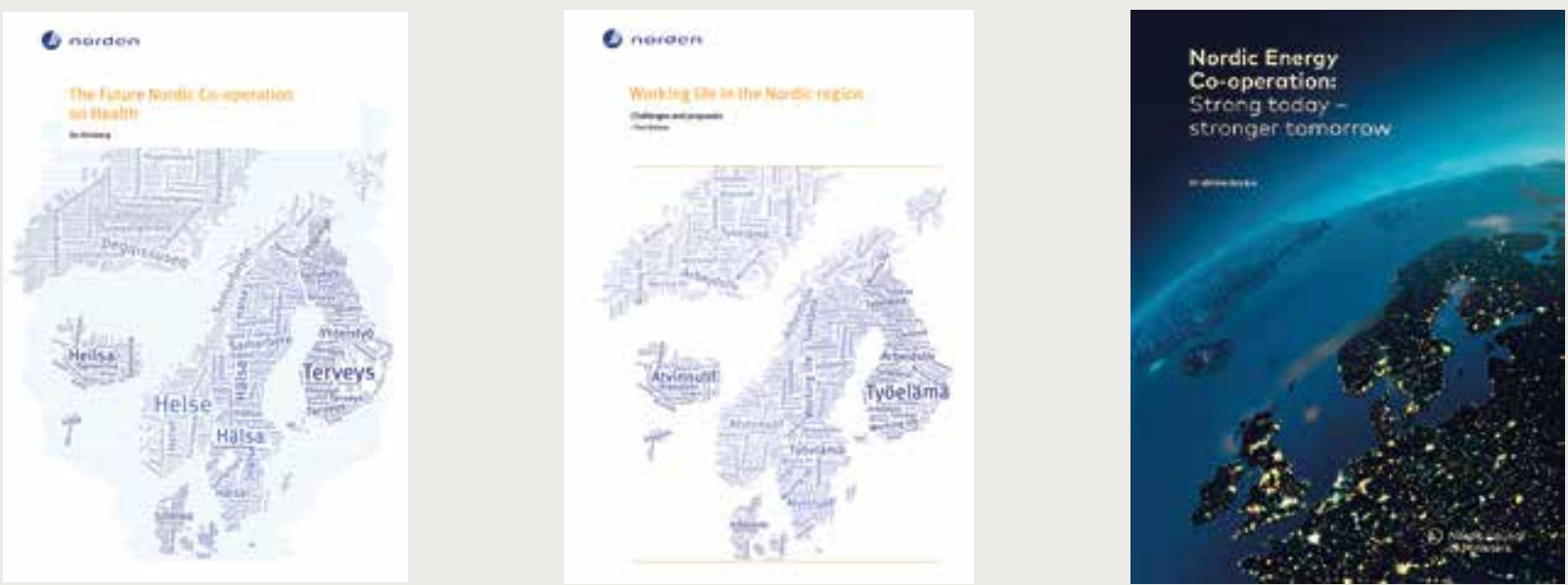
Pohjoismaiden ministerineuvosto

Norden Hus

Ved Stranden 18

DK-1061 København K

www.norden.org

Tässä raportissa esitellään oikeusalan pohjoismaisen yhteistyön haasteita ja mahdollisuuksia. Oikeusyhteistyö on pohjoismaisen yhteistyösopimuksen (Helsingin sopimus) perusteella pohjoismaisen yhteistyön keskeinen osa-alue. Raportti sisältää joukon ehdotuksia oikeusyhteistyön vahvistamiseksi.

Raportin mukaan tiiviimmän oikeusyhteistyön avulla voitaisiin parantaa yksittäisten maiden lainsäädäntöä, torjua Pohjoismaiden välisiä eitoivottuja rajaesteitä sekä edistää pohjoismaista mallia esimerkkinä maailmanyhteisölle. Vahvempi oikeusyhteistyö on tärkeässä asemassa, kun Pohjola pyrkii olemaan maailman integroiduin alue Pohjoismaiden pääministereiden vuonna 2016 antaman julkilausuman mukaisesti.

Raportin on kirjoittanut Oslon yliopiston emeritusprofessori Inge Lorange Backer, jolla on pitkä kokemus oikeusalan pohjoismaisesta yhteistyöstä. Backer toimi Norjan oikeusministeriön lakiasiainosaston osastopäällikkönä ja Pohjoismaiden ministerineuvoston oikeusyhteistyön virkamieskomitean norjalaisena jäsenenä vuosina 1995-2008. 